Portland State University

PDXScholar

$5-5-2008$

\title{
Bonneville Power Administration and the Creation of the Pacific Intertie, 1958 -1964
}

Joshua D. Binus

Portland State University

Follow this and additional works at: https://pdxscholar.library.pdx.edu/open_access_etds

Part of the United States History Commons

Let us know how access to this document benefits you.

\section{Recommended Citation}

Binus, Joshua D., "Bonneville Power Administration and the Creation of the Pacific Intertie, 1958 -1964" (2008). Dissertations and Theses. Paper 1724.

https://doi.org/10.15760/etd.1723

This Thesis is brought to you for free and open access. It has been accepted for inclusion in Dissertations and Theses by an authorized administrator of PDXScholar. Please contact us if we can make this document more accessible: pdxscholar@pdx.edu. 


\section{THESIS APPROVAL}

The abstract and thesis of Joshua D. Binus for the Master of Arts in History were presented May 5, 2008 and accepted by the thesis committee and the department.

\section{COMMITTEE APPROVALS:}

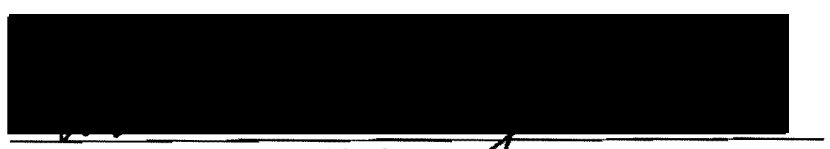

William L. Lang, Chair

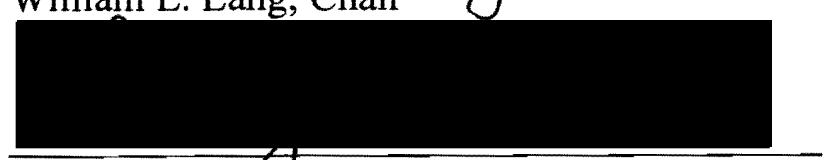

David A. Johnson

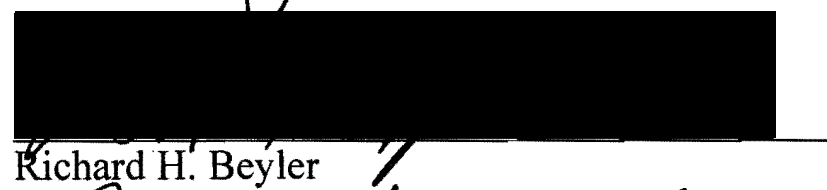

DEPARTMENT APPROVAL:

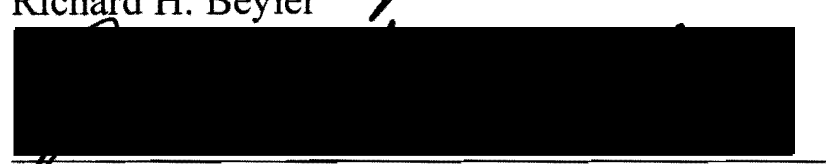

Jeffrey R. Hammarlund

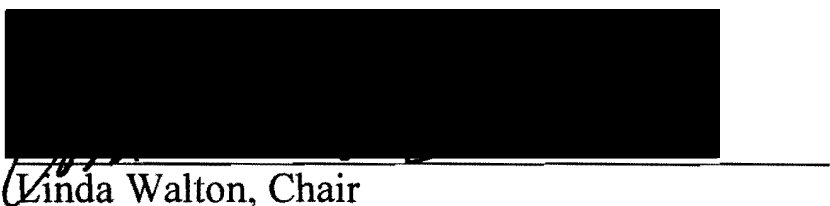

Department of History 


\begin{abstract}
An abstract of the thesis of Joshua D. Binus for the Master of Arts in History presented May 5, 2008.
\end{abstract}

Title: Bonneville Power Administration and the Creation of the Pacific Intertie, $1958-1964$

Construction of the Pacific Northwest-Pacific Southwest Intertie (also known as the Pacific Intertie) began in 1964, following the culmination of a series of interrelated negotiations which included: 1) the planning for the construction and operation of the Pacific Intertie; 2) the passage of federal legislation that put limits on the export of electricity from the regions where it was generated; and 3) the full ratification of the Columbia River Treaty between the United States and Canada. By 1970 , with construction complete, the Pacific Intertie allowed for the movement of more than 4,000,000 kilowatts of power among the electrical systems of British Columbia and eleven Western states, including 243 rural electrical cooperatives, municipal systems, and other public agencies. It had essentially become the backbone of the largest electrical grid in the Western world. In addition to widening the marketing area available to power producers throughout the grid, the Pacific Intertie also integrated the operations of the nation's largest hydropower system (Bonneville Power Administration), the largest privately owned electrical system (Pacific Gas \& 
Electric), and the largest municipal power system (L.A. Department of Water and

Power) in the country. 
BONNEVILLE POWER ADMINISTRATION AND THE CREATION OF THE

PACIFIC INTERTIE, 1958 - 1964

\author{
by \\ JOSHUA D. BINUS
}

A thesis submitted in partial fulfillment of the requirements for the degree of

\author{
MASTER OF ARTS \\ in \\ HISTORY
}

Portland State University

2008 


\section{Acknowledgments}

The help I have received to write this thesis goes back several years, and I am certain there are more people that provided assistance along the way than I have thought to mention here. I would first like to thank my advisor, Bill Lang, for his steady mentorship over the years. His knowledge of Columbia River history, guidance in regards to research methods, and editing style did much to shape this thesis. Similarly, the editorial staff of the Pacific Historical Review (David Johnson, Carl Abbott, and Susan Wladaver-Morgan) did much to help strengthen my research, writing, and editing skills, while providing well-timed encouragement along the way. I will always treasure the time spent studying under and working with you all.

Of course, this thesis would not have been possible if not for the assistance of many archivists and librarians. Susan Karren, John Fitzgerald, Patty McNamee, Sarah Nelson, and Damon Jones, all archivists at the National Archives in Seattle, were absolutely critical players in my efforts to work through "the wall" of BPA records. Linda Kuriger, Kelly Laslie, Tina Kay, and Mark Rogen, at the Bonneville Power Administration's Library, were likewise a great source of support in my efforts to glean what I could from the Bonneville records held in Portland.

Most importantly, I must thank Andrea and Alia, my wife and daughter, whose support in this endeavor has been unwavering. I love you both. 
Acknowledgments $\quad$ i

List of Figures

Pacific Northwest-Pacific Southwest Intertie, 1964 iv

(From Pacific Northwest-Pacific Southwest Intertie, 1964,

Bonneville Power Administration Library)

Preface

$\mathrm{v}$

Major Hydroelectric Projects of the Pacific Northwest, $1965 \quad$ xviii (From Report of a Missouri River Basin-Pacific

Northwest EHV Interconnection (1965), Bonneville

Power Administration Library)

Chapter 1: BPA Surplus Power and the California Market 1

$\begin{array}{ll}\text { Chapter 2: Federal Leadership } & 11\end{array}$

Chapter 3: The Federal Yardstick 21

$\begin{array}{ll}\text { Chapter 4: Protecting Regional Interests } & 37\end{array}$

$\begin{array}{ll}\text { Chapter 5: Congressional Appropriations } & 47\end{array}$

Chapter 6: The Columbia River Treaty and the Canadian Entitlement 66

Chapter 7: The Confluence $\quad 90$

$\begin{array}{ll}\text { Conclusion: } & 104\end{array}$

$\begin{array}{ll}\text { References: } & 108\end{array}$ 


\section{$\underline{\text { List of Figures }}$}

Figure

Title

Page

1 Principle Transmission Circuits Involved in a Pacific

Northwest-California Intertie, 1960 (From Bonneville Power

Administration, "Study of a high voltage electrical interconnection between the Pacific Northwest and California," Feb. 1960, PNW-PSW Intertie Documents, Box 18118, RG 305 , NARA Seattle)

2 "Fitness Program," by Carl Bonelli, Oregon Journal, June 30, 1964 (From the Carl Bonelli Collection, MSS 5537, Oregon Historical Society)

3 Existing and Proposed Federal Transmission System, Pacific Northwest, 1949 (From U.S. Army Corps of Engineers "Review of reports on, and preliminary examinations and surveys of, the Columbia River and tributaries," submitted to Congress in 1949 (printed as House Doc. 531 in 1951)

$4 \quad$ Pacific Northwest-Pacific Southwest Intertie, Federal

Yardstick, March 1964 (From PNW-PSW Intertie Documents, Box 18118, RG 305, NARA Seattle)

5. "For the Common Good," by Carl Bonelli, Oregon Journal, Sept. 16, 1964 (From the Carl Bonelli Collection, MSS 5537, Oregon Historical Society)

6 “O.K. It's a Deal," by Carl Bonelli, Oregon Journal, Jan. 23, 1964 (From the Carl Bonelli Collection, MSS 5537, Oregon Historical Society) 


\section{PACIFIG NORTHWEST - SOUTHWEST INTERTIE}

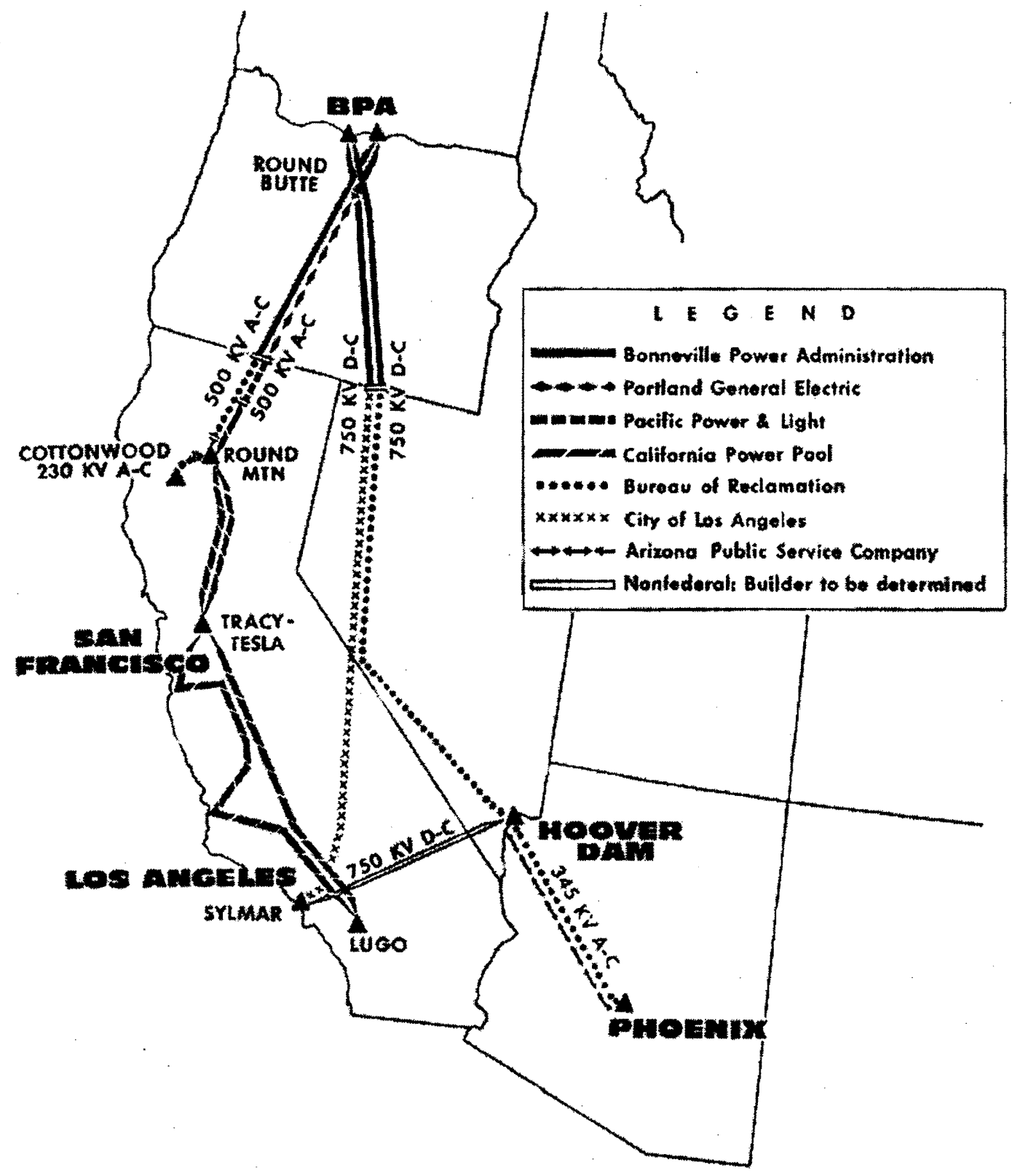




\section{Preface}

This thesis began as a historical study of the John Day Dam on the Columbia River. In the process of exploring the role that dam has played in the electrical grid operated by the Bonneville Power Administration (BPA), it became apparent to me that a much more important and interesting history was in need of being writtennamely the creation of the Pacific Northwest-Pacific Southwest Intertie system (hereafter referred to as the Pacific Intertie). ${ }^{1}$ The construction of the Pacific Intertie in the 1960s represents a milestone in American history in regards to the long distance transmission of high voltage electrical currents. Never before had the country's public and private interests converged to integrate so many sub-regional electrical systems into such a large electrical grid. For this reason alone, it deserves more attention by scholars. Still, while the technological achievements related to the construction and operation of the Pacific Intertie are important, I argue that they are less important than a related series of negotiations that took place between the United States and Canada and between the BPA and a range of public and private power interests at local, state, regional, federal, and international levels.

While exploring the history of the Pacific Intertie, it also became apparent to me that I was researching the origins of the American West's electrical grid. By the mid-twentieth century there was already a high level of electrical interconnection linking together various sub-grids across the West (and for that matter, throughout the entire continent); however, none of the connections between local distribution systems

\footnotetext{
${ }^{1}$ High voltage electrical power lines are typically referred to as "interties" within the electrical industry.
} 
throughout the region were engineered to carry excessively large electrical loads of 500 kilovolts $(\mathrm{kv})$ or more. The construction of the Pacific Intertie during the $1960 \mathrm{~s}$ was unique because of its geographical reach, its ability to transport vast amounts of energy, and the way in which power managers used it to take advantage of diversities within the territories it spanned.

Rather than discussing the intellectual origins of the American West's electrical grid, its steady development through second half of the twentieth century, or a detailed analysis of its operations, this historical study attempts to explain how the backbone of the Western grid grew from the successful outcomes of three intersecting arenas of negotiation, negotiations that through the early to mid-1960s became increasingly intertwined and ultimately interdependent. These three spheres of negotiation included: 1) the planning for the construction and operation of the Pacific Intertie; 2) the passage of federal legislation that put limits on the export of electricity from the regions where it was generated; and 3) the full ratification of the Columbia River Treaty between the United States and Canada.

The successful culmination of these negotiations in 1964 allowed for the creation of an electrical grid that by 1970 included Washington, Oregon, Idaho, and California, along with parts of British Columbia, Montana, Utah, Nevada, and Arizona. As the century wore on, the grid expanded into Alberta, moved further toward the Rockies, and even stretched across the nation's southern border into Mexico. 
The wide-ranging geography of this electrical grid created opportunities to maximize the efficiency of electrical operations, largely by taking advantage of diversities within the system. For example, thermal plants throughout the Southwest, which operate best if allowed to run non-stop at a consistent level of output, have largely been spared the necessity of ramping up production during predictable daily peaks in power usage. Following the creation of the Pacific Intertie system, the grid's hydropower plants in the Northwest have been able to supply much of the energy needed across the grid by producing a surge of power each day during breakfast and dinner times. At night, as the reservoirs recharge and the thermal plants produce more power than local markets can absorb, much of the excess power is sent northward, completing a reciprocal exchange of power that has been going on now for decades.

The expanse of the West's new electrical grid also allowed for seasonal exchanges of power between the Northwest and Southwest. Hot, dry summers in the Southwest created conditions for annual peaks in electrical loads to supply power for irrigation pumps and air conditioners. The Northwest, with its rivers swollen with snowmelt during its comparatively mild summers, exported surplus power south to meet the Southwest's needs. Conversely, demand for space heating during the cold winters in the Northwest created annual peaks in electrical loads at the same time when water levels were at their annual lows. At such times, the Southwest, with its mild winters, would send power north.

Power planners had understood the potential opportunities this kind of symbiotic relationship offered the Pacific Coast states since at least the mid-1930s, 
when the Pacific Northwest Regional Planning Commission first officially

suggested the construction of an Intertie connecting the grids of the Pacific Northwest and California. ${ }^{2}$ Still, while various proposals began circulating through the halls of Congress as early as 1948, it took another decade until the project would begin gaining traction on Capital Hill. ${ }^{3}$ It was not until 1958 that the BPA, whose budget had recently been pushed into the red from the combination of a downturn in the region's aluminum industry and reduced residential demand (stemming from a mild winter), began planning for the creation of a relatively short intertie to market excess power from their grid across the California state line to the Pacific Gas \& Electric Company. It is here, in 1958, that the following narrative begins.

\section{A note on sources}

It is important to point out that the following history is, to a large degree, a work in progress. The primary source material on the topic is mountainous and spread across a geography that reaches from Portland to Washington D.C. and from British Columbia to Arizona. The following history has been crafted largely from source material found in the Library of the BPA (Portland) and the National Archives (Pacific

\footnotetext{
${ }^{2}$ Bonneville Power Administration, Pacific Intertie (Portland, Oreg.: Bonneville Power Administration, ca. 1984). An earlier call for the construction of a connecting line between British Columbia and Southern California was made by Carl Edward Magnusson, director of the Engineering Station at the University of Washington in 1919. Magnusson's suggestion for a line appeared to be related to efficiencies related more to the public ownership of such a line, rather than to the efficiencies stemming from production and consumption diversities across the region's systems. See Gus Norwood, Columbia River Power for the People: A History of Policies of the Bonneville Power Administration (Washington, D.C.: U.S. Government Printing Office, 1981), 52.

${ }^{3}$ Norwood, Power for the People, 237.
} 
Alaska Region, Seattle). Repeated visits to both locations have led to new findings, and in the case of the BPA, where the staff have recently begun systematically cataloging their own library, there is much more intertie-related material that I'm sure will eventually become accessible.

As I was doing research in Seattle, there were several holdings in the National Archives that had been documented as being "recalled to the BPA" and "subsequently lost."4 These materials were related specifically to the Pacific Intertie and the Columbia River Treaty. An investigation by the archivists at the National Archives turned up nothing in their own records center (thinking perhaps they had been reaccessioned at a later date and stored somewhere else), and there was nothing at the BPA to indicate the location of the lost files. However, on a later visit to the BPA Library, I did find one of the "lost" sources, the minutes from the BPA Administrator's meetings during Charles Luce's tenure, while randomly perusing the shelf space around something else I was retrieving. It was uncatalogued. I suspect that there may be other "lost" sources uncatalogued on their shelves as well.

Fortunately, many of Bernard Goldhammer's (BPA Power Manager) files were not pulled from the National Archive's holdings, for it was within his voluminous files that I found much of the substantive correspondence between the BPA and its various government, private sector, and public utility contacts related to the planning and

\footnotetext{
${ }^{4}$ The records "retrieved from FRC [Federal Records Center] and then lost at BPA Headquarters" were removed in 1972, 1981, 1991, and 1992. These records include, but are likely not limited to: RG 305, Accession \# 305-77-0014 (150093-02), Power Resources Project Files, 1943 - 65 (Power Study Data); RG 305, Accession \# 305-75-A1 121 (10305-06), Program Subject Files, 1955 - 1971 (Columbia River Treaty Files); RG 305, Accession \# 305-81-0033 (947705), Minutes of Administrator's Staff Meetings (1960 - 1965); and RG 305, Accession \# 305-73A0069 (47985-86), Project Subject Files, 1959 - 67 (Canadian Storage, 1959 - 65; Interconnections \& Interties, 1960-67).
} 
construction of the Pacific Intertie and the passage of the regional preference legislation. Another set of files kept by a BPA employee, Henderson M. McIntyre (Chief, Branch of Power Resources), contained an important cache of correspondence generated from the BPA's efforts related to Columbia River Treaty that were particularly focused on negotiations over the fate of Canada's downstream benefits stemming from the treaty. Together, these manuscript collections account for the largest bulk of material - approximately 1,500 pages - from which much of the following narrative has been created.

Following the advice of my advisor, other mentors, and peers--whose mantra during the past two years has been to "just finish it," I am writing this narrative with the knowledge that further research will no doubt fine-tune several points raised in this master's thesis. An exploration of the City of Los Angeles Water and Power Department's records, for example, will no doubt help shed further light on the motives and strategies of these important participants in Pacific Intertie's creation. Still, I'm confident that my BPA-centric historical analysis will help forward scholarship on this important topic by providing a sound foundation that other scholars build upon. Furthermore, because the BPA was the most active and central organization involved in the negotiations surrounding the Pacific Intertie, I am confident that a historical analysis stemming largely from their correspondence files will not to be too far off the mark, even if it is ultimately incomplete.

As of this writing there is a surprising dearth of secondary literature on the historical formation of the United State's electrical transmission infrastructure. For 
the American West, what little exists is focused primarily on an earlier era of development covering the period from the end of the nineteenth century up to World War II. Most notable in this regard is Jay Brigham's Empowering the West: Electrical Politics Before FDR (1998) and James C. Williams' Energy and the Making of Modern California (1997). While Brigham's work is primarily focused on the battles between public and private power interests, his case studies on Seattle and Los Angeles are helpful for those interested in building a foundation of knowledge on the region's energy history. Likewise, Williams' study of the development of California's energy systems stands out for the breadth of information offered to his readers on the topic. While Bringham does not extend the timeframe for his analysis beyond the Great Depression, Williams does. Unfortunately—at least for my purposesWilliams's focus on the post-war period is primarily on California's history and geography of power production (and to a lesser extent on power consumption). Once his analysis moves beyond the public-private power struggles of the 1920s and 1930s and the resulting status of California's sub-regional power grids, he says nothing more on the evolution of the state's electrical transmission systems. Neither the Pacific Intertie nor the Bonneville Power Administration, let alone the Columbia River system, are mentioned at all. ${ }^{5}$

With a couple important exceptions, the majority of related work carried out by historically oriented scholars of the American West tends to focus on the development of water resources. However, these studies routinely avoid any detailed discussion

\footnotetext{
${ }^{5}$ Jay L. Bringham, Empowering the West: Electrical Politics Before FDR (Lawrence: University Press of Kansas, 1998); James C. Williams, Energy and the Making of Modern California, (Akron, Oh.: University of Akron Press, 1997).
} 
about the relationships between the West's water projects and the electrical grids in which they are located. These analyses offer much insight into how the West's rivers have been reshaped to serve the needs of an immigrant society hungry for power of all kinds (cultural, economical, political, and electrical), and they are especially helpful in understanding the many conflicts surrounding water development projects. Most notable in this regard are Norris Hundley, Jr.'s The Great Thirst: Californians and Water: A History (2001); Donald Worster's Rivers of Empire: Water, Aridity, and the Growth of the American West (1985); Donald Pisani's Water and American Government: The Reclamation Bureau, National Water Policy, and the West, 1902 1935 (2002); and Mark Reisner's Cadillac Desert: The American West and Its Disappearing Water (1986). ${ }^{6}$

Similarly, Samuel Hays' Conservation and the Gospel of Efficiency: The Progressive Conservation Movement, 1890 - 1920 (1959), Richard Lowitt's The New Deal and the West (1984), and Gerald Nash's The Federal Landscape: An Economic History of the Twentieth Century West (1999) provided guidance for gaining a more nuanced understanding of the federal government's role in developing much of the American West's electrical infrastructure. ${ }^{7}$ Still, while these works were helpful in

\footnotetext{
${ }^{6}$ Norris Hundley, Jr., The Great Thirst: Californians and Water: A History (Berkeley: University of California Press, 2001); Donald Worster, Rivers of Empire: Water, Aridity, and the Growth of the American West (New York: Oxford University Press, 1985); Donald Pisani, Water and American Government: The Reclamation Bureau, National Water Policy, and the West, 1902 - 1935 (Berkeley: University of California Press, 2002); and Marc Reisner, Cadillac Desert: The American West and Its Disappearing Water, (New York: Penguin Books, 1986).

${ }^{7}$ Samuel P. Hays, Conservation and the Gospel of Efficiency: The Progressive Conservation Movement, 1880 - 1920 (Pittsburgh, Penn.: University of Pittsburgh Press, 1999, originally published by Harvard University Press, 1959); Richard Lowitt, The New Deal and the West (Norman: University of Oklahoma Press, 1984); and Gerald Nash, The Federal Landscape: An Economic History of the Twentieth Century West (Tucson: University of Arizona Press, 1999).
} 
my efforts to contextualize the histories surrounding the Pacific Intertie, none of these authors addressed its existence directly.

Other works are more specifically focused on the Columbia River Basin and provide important context to the development of the region's hydropower system and related conflicts. These include: William L. Lang and Robert Carriker's Great River of the West: Essays on the Columbia River (1999), William Dietrich's Northwest Passage: The Great Columbia River (1995), Richard White's The Organic Machine: The Remaking of the Columbia River (1995), Daniel Ogden, Jr.'s "The Development of Federal Power in the Pacific Northwest" (1949), Charles McKinley's Uncle Sam in the Pacific Northwest: Federal Management of Natural Resources in the Pacific Northwest (1952), Franklyn D. Mahar's "The Politics of Power: The Oregon Test for Partnership" (1974), Philip J. Funigiello's “The Bonneville Power Administration and the New Deal" (1973), William F. Willingham's Army Engineers and the Development of Oregon: A History of the Portland District U.S. Army Corps of Engineers (1983), Phyllis Komerek De Kuna's Public versus Private Power During the Truman Administration (1977), Keith Petersen and Mary Reed's Controversy, Conflict and Compromise: A History of the Lower Snake Development (1994), Karl Boyd Brooks' Public Power, Private Dams: The Hells Canyon High Dam Controversy (2006), Kai N. Lee and Donna Lee Klemka's Electric Power and the Future of the Pacific Northwest (1980), Jeff Hammarlund's “Oregon's Role as an Energy Innovator: A Historical Perspective" (2002), Cain Allen's “"They Called It Progress': Indians, Salmon, and the Industrialization of the Columbia River" (2000), 
and the National Research Council's Managing the Columbia River: Instream

Flows, Water Withdrawals, and Salmon Survival (2004). ${ }^{8}$

For a background on the Columbia River Treaty itself, the most informative

works include Neil Swanson's Conflict over the Columbia: The Canadian Background

to an Historic Treaty (1979), John V. Krutilla's The Columbia River Treaty: The

Economics of an International River Basin Development (1967), James F. Hanks'

"The Columbia River Treaty: A Case Study of International River Basin Development

with Emphasis on Power Production" (1970), John Murray McMenemy's “The

Columbia River Treaty, 1961 - 1964: A Study of Opposition and Representation in

the Canadian Political System" (1969), and a richly informative chapter in John

Elliot's The Sociology of Natural Resources (1981). While much of the analysis of the

treaty tends to focus on which country got the better deal, these works helped

\footnotetext{
${ }^{8}$ William L. Lang and Robert C. Carriker, eds., Great River of the West: Essays on the Columbia River (Seattle: University of Washington Press, 1999); William Dietrich, Northwest Passage: The Great Columbia River (Seattle: University of Washington Press, 1995); Richard White, The Organic Machine: The Remaking of the Columbia River (New York: Hill and Wang, 1995); Daniel Ogden, "The Development of Federal Power Policy in the Pacific Northwest" (Ph.D. dissertation, University of Chicago, 1949); Charles McKinley, Uncle Sam in the Pacific Northwest: Federal Management of Natural Resources in the Columbia River Valley (Berkeley, University of California Press, 1952); Franklyn D. Mahar, "The Politics of Power: The Oregon Test for Partnership," Pacific Northwest Quarterly 65:1 (1974), 29 - 37; Philip J. Funigiello, "The Bonneville Power Administration and the New Deal," Prologue 5:2 (1973): 89 - 97; William F. Willingham, Army Engineers and the Development of Oregon: A History of the Portland District U.S. Army Corps of Engineers (Washington, D.C.: Government Printing Office, 1983); Phyllis Komarek De Luna, Public Versus Private Power During the Truman Administration: A Study of Fair Deal Liberalism (New York: Peter Lang Publishing, 1977); Keith C. Petersen and Mary E. Reed, Controversy, Conflict and Compromise: $A$ History of the Lower Snake Development (Washington, D.C.: Government Printing Office, 1994); Karl Boyd Brooks, Public Power, Private Dams: The Hells Canyon High Dam Controversy (Seattle: University of Washington Press, 2006); Kai N. Lee and Donna Lee Klemka, Electric Power and the Future of the Pacific Northwest (Seattle, University of Washington Press, 1980); Jeff Hammarlund, "Oregon's Role as an Energy Innovator: A Historical Perspective," Oregon's Future 3:1 (2002), 10 16; Cain Allen, "'They Called It Progress': Indians, Salmon, and the Industrialization of the Columbia River" (master's thesis, Portland State University, 2000); and National Research Council, Managing the Columbia River: Instream Flows, Water Withdrawals, and Salmon Survival (Washington, D.C.: National Academies Press, 2004).
} 
contextualize the history of the treaty and confirmed information gleaned from the

BPA's records at the National Archives. ${ }^{9}$

Most helpful in getting a better understanding of Pacific Intertie and the

historical development of the West's electrical transmission infrastructure were

Michael Blumm's essay, "The Northwest's Hydroelectric Heritage," in Northwest

Lands, Northwest Peoples: Readings in Environmental History (1999), and Gus

Norwood's Columbia River Power for the People: A History of Policies of the

Bonneville Power Administration (1981), Gene Tollefson's BPA and the Struggle for

Power at Cost (1987), and Vera Springer's Power and the Pacific Northwest (1976),

all contracted by the BPA; and Douglas Norwood's "Administrative Challenge and

Response: The Role of the Bonneville Power Administration in the West Coast

Intertie Decision" (1966). ${ }^{10}$

Blumm's work, while necessarily topical, provides a basic understanding of

the formation of the Northwest's regional electrical grid, essentially built up from an

original triangular foundation joining together Grand Coulee Dam, Bonneville Dam

\footnotetext{
${ }^{9}$ Neil Swanson, Conflict over the Columbia: The Canadian Background to an Historic Treaty (Montreal: McGill-Queen's University Press, 1979); John V. Krutilla, The Columbia River Treaty: The Economics of an International River Basin Development (Washington, D.C.: Resources for the Future, 1967); James F. Hanks, "The Columbia River Treaty: A Case Study of International River Basin Development with Emphasis on Power Production" (master's thesis, University of Oregon, 1970); John Murray McMenemy, "The Columbia River Treaty, 1961 - 1964: A Study of Opposition and Representation in the Canadian Political System" (master's thesis, University of Toronto,1969); and John Elliot, The Sociology of Natural Resources (Toronto: Butterworth \& Co., 1981).

${ }^{10}$ Michael C. Blumm, "The Northwest's Hydroelectric Heritage," in Northwest Lands, Northwest Peoples: Readings in Environmental History, eds. Dale D. Goble and Paul W. Hirt (Seattle: University of Washington Press, 1999) 229 - 263; Norwood, Power for the People; Gene Tollefson, BPA and the Struggle for Power at Cost (Portland, Ore.: Bonneville Power Administration, 1987); Vera Springer, Power and the Pacific Northwest: A History of the Bonneville Power Administration (Portland, Ore.: Bonneville Power Administration, 1976); and Douglas Norwood, "Administrative Challenge and Response: The Role of the Bonneville Power Administration in the West Coast Intertie Decision" (bachelor of arts thesis, Reed College, 1966).
} 
(and Portland), and the Seattle/Tacoma area. Blumm also makes a connection between the brokering of the Columbia River Treaty and the subsequent marketing of power southward into California. Additionally, he highlights the importance of the Northwest's hydropower plants in supplying peak power demands across the electrical grid. ${ }^{11}$

Gus Norwood's Power for the People, Tollefson's BPA and the Struggle for Power at Cost, and Springer's Power and the Pacific Northwest together provide an indispensable resource for understanding the history of the BPA. They are simply the best (and only) reference materials on the agency's history in print. They provided me with background information on BPA's policies and an overview of the efforts to create the Northwest's transmission grid, including the BPA's efforts to connect that grid to California's burgeoning electrical markets.

The most informative secondary source for this study has naturally been Douglas Norwood's "Administrative Challenge and Response." I first reviewed this thesis while doing research on the John Day Dam, and I was struck by the speed at which his analysis of the Intertie decision appeared, just two years after its approval by Congress in 1964. I was immediately curious how accessible the BPA records had been to an undergraduate so soon after such contested negotiations had come to a close-and before the Pacific Intertie's construction had even been completed. I could not help but wonder: Was this thesis a reliable source?

The answer, as it turns out, is yes; furthermore, his findings-at least in regards to the negotiations surrounding the Pacific Intertie-parallel my own. The

\footnotetext{
${ }^{11}$ Blumm, "The Northwest's Hydroelectric Heritage," $269-275$.
} 
biggest difference is that he relied extensively upon unrecorded interviews with the BPA's staff. This thesis, in comparison, relies heavily upon publicly accessible records kept by some of the same staff he interviewed. Another difference between our studies is that Norwood's primary focus is the administrative decision-making process that guided negotiations. This thesis, instead, focuses on the discovery and synthesis of primary source materials in the construction of a historical narrative on the creation of the Pacific Intertie.

Another difference between Norwood's work and my own is that he relied heavily on transcripts from Congressional hearings regarding the Pacific Intertie's authorization and its subsequent appropriations. After comparing his use and interpretation of the hearings with the archived correspondence between the Department of Interior, Bonneville Power Administration, Congressional committee members, and others involved, which often included excerpts from the hearings themselves, I found his interpretations to be both reliable and insightful. 


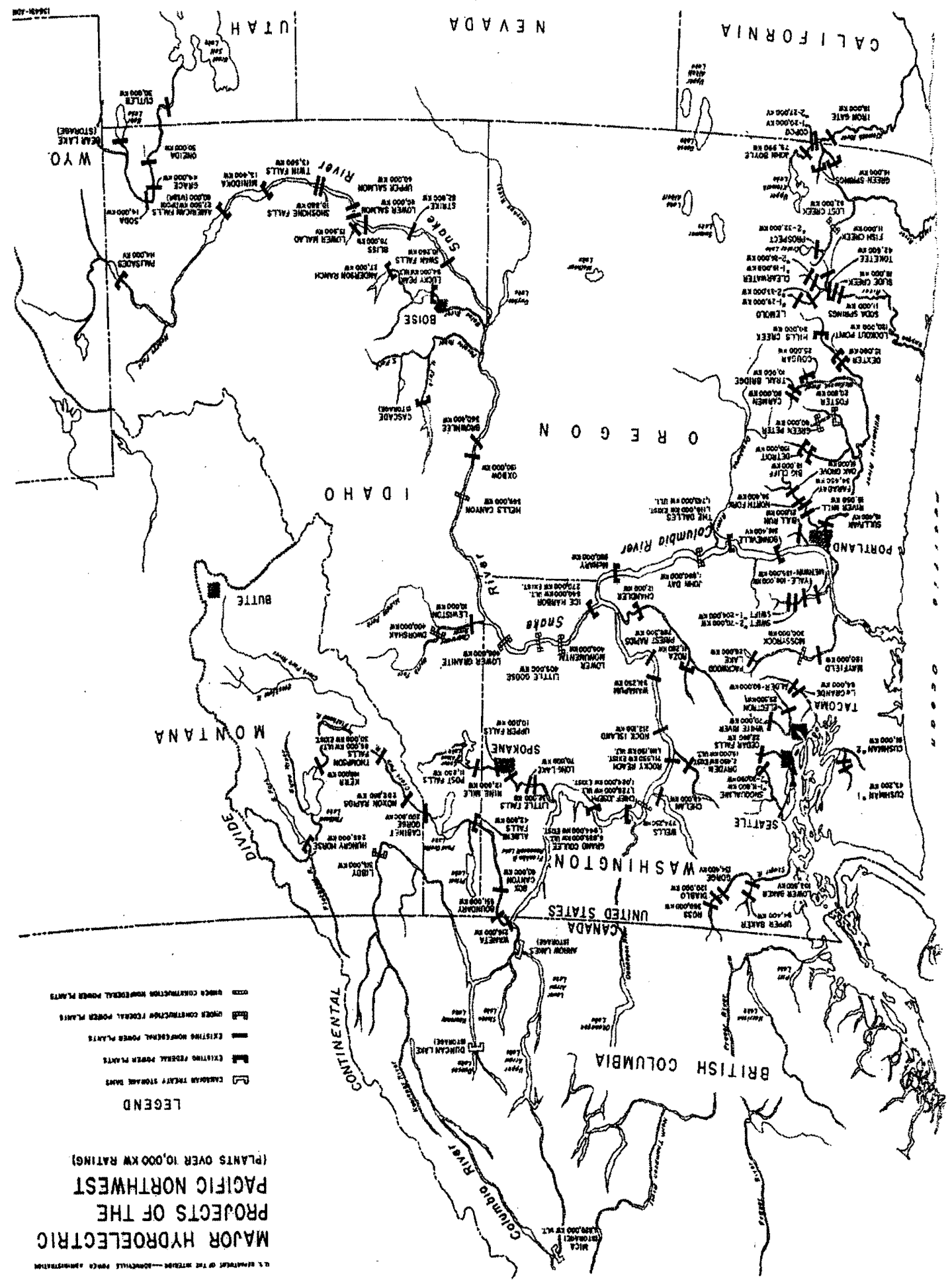




\section{CHAPTER 1: BPA Surplus Power and the California Market}

During the mid-twentieth century, Americans engineered the Columbia River system in an extensive effort to maximize the benefits it could provide to the Pacific Northwest. The remade river was designed to irrigate farms, increase trade, control floods, provide recreation, and - most importantly - to produce electricity. The single-most transformative change in the history of the Columbia Basin involved the proliferation of massive dams built by the U.S. Army Corps of Engineers, the U.S. Bureau of Reclamation, and various public and private utilities. Collectively, these dams turned the regions' rivers—or at least large stretches of them—into slow-moving lakes. On the Columbia, efforts by the Army Corps to implement their Main Control Plan worked to reduce the spring and summer freshet of snowmelt so that the seasonally abundant water could be put to the above-mentioned "beneficial" uses yearround.

As each federal dam was authorized by Congress, it was understood that they would be self-liquidating, meaning that they would pay for themselves through the production and sale of the electricity that they generated. This payment strategy became institutionalized when Congress passed the Bonneville Power Act in 1937, creating the self-funded Bonneville Power Administration and charging it with the responsibility of marketing, transmitting, and selling electricity generated from the region's federal power-producers. 
With the completion of each successive dam on the river, Bonneville's debt grew larger, but so too did its customer base. Beginning in the 1940s, as part of the war effort, Bonneville's repayments to the federal treasury were also given a boost by the attraction of energy-intensive aluminum production plants to their electrical territory. The aluminum plants purchased large volumes of "firm" power from the BPA, and after 1948, also began purchasing sizable blocks of interruptible "secondary" power as well. ${ }^{12}$ Electricity sold from within the predictable volume of power able to be generated during the lowest water levels on record is considered "firm." Any power produced during periods of higher water flow is classified as "secondary" power (often also referred to as "surplus" power) and is less expensive because its availability can be withdrawn if water levels drop. By contracting for large volumes of both firm and secondary power, the Northwest's aluminum industry proved to be a dependable source of revenue for the BPA from the 1940s into the 1950s.

By the mid-1950s, following the authorization and appropriation of funds for additional dams by Congress, the BPA's debt threatened to outpace its available market. In 1958, spurred by a mild winter (which reduced heating demands) and an economic recession that hit the region's aluminum industry particularly hard, the BPA began to post annual deficits. For the BPA, this was especially frustrating, because roughly $\$ 20$ to $\$ 30$ million worth of water was "wasted" that year simply because they did not have any customers for the power it would have generated had it passed

\footnotetext{
${ }^{12}$ Norwood, Power for the People, 136.
} 
through some turbines on the way to the ocean. ${ }^{13}$ This "surplus" power needed buyers for Bonneville to get back in the black. Unfortunately for Bonneville, because the availability of surplus power is highly unpredictable, finding buyers proved to be a difficult proposition. ${ }^{14}$

In 1958, under the leadership of Administrator William Pearl, the BPA started negotiating a contract with California-based Pacific Gas \& Electric (PG\&E) to buy at least $\$ 2,000,000$ worth of the BPA's surplus power. To get the electricity, PG\&E planned to build an $80-$ mile, $230-\mathrm{kv}$ intertie from its Pit River plant in northern California to connect with a 230-kv line owned by the California-Oregon Power Company (COPCO) in Klamath Falls, which was connected to Bonneville's transmission system. ${ }^{15}$

The Northwest's Congressional delegation and state governors responded to the potential intertie by quickly mobilizing against it. At issue was the previously unanticipated application of the "preference clause" in the BPA's authorizing charter, which required that public utilities have first call on power marketed by Bonneville. More to the point, many Northwestern politicians were worried that if California's public utilities were able to gain access to the Northwest's grid, either as recipients of

\footnotetext{
${ }^{13}$ Floyd E. Dominy, "A New Power Giant Materializes on the West Coast," Reclamation ERA 51:3 (August 1965): 66-67.

${ }^{14}$ Prior to experiencing their first deficits in 1958 , the BPA was $\$ 78,800,000$ ahead in their repayment schedule of federal investments into the Columbia River Basin. By the end of fiscal year 1961, that surplus had been reduced to $\$ 37,800,000$. According to Luce, "Future deficits are predicted for the next four or five years... if this trend is not reversed, it will be difficult to avoid a rate increase." See "Power for Progress-II: The New Program of Bonneville Power Administration for the Pacific Northwest: Updated Summary of Speeches and Statements by Charles F. Luce, Bonneville Power Administrator (Compiled as of March 30,1962, and supersedes compilation dated July 15, 1961)," 4-5, Library of the Bonneville Power Administration.

${ }^{15}$ Gus Norwood, Power for the People, 240.
} 
third-party energy transfers or by building connecting power lines on their own, than they could have, by law, demanded public preference to BPA power, at the expense of the Northwest's own private utilities and industries. Hearings were subsequently scheduled in the Senate Interior and Insular Affairs Committee on April 8 and 9, 1959, and ultimately led to a resolution passed on May 19 that requested:

That the Secretary of the Interior direct the Bonneville Power Administration to conduct, in cooperation with the Bureau of Reclamation, a study and analysis of the feasibility and desirability of a high-voltage interconnection for disposal of surplus secondary energy between the Federal power systems in the Pacific Northwest and California and report to the Congress thereon, together with conclusions and recommendations not later than July 15, 1959...

BE IT FURTHER RESOLVED, that the Committee request the Secretary of the Interior to suspend all negotiations for any interconnection or sale of surplus power until the Congress has had the opportunity to consider and act on the study and analysis requested by this situation. ${ }^{16}$

In February 1960, after a deadline extension, the BPA and Bureau of

Reclamation reported their findings to the committee. After pointing out the Congressional direction to focus the analysis on "the disposal of surplus energy between the federal systems," Administrator Pearl relayed his agency's primary conclusion: "The study shows that little or no benefits result from the coordination of the Federal surplus secondary energy in the Pacific Northwest and the Central Valley system in northern California." $" 17$ Even so, Pearl reported Bonneville's original

\footnotetext{
16 "Conference regarding study of feasibility of high voltage transmission interconnection between California and the Pacific Northwest," 9 - 10, June 25, 1959, PNW-PSW Intertie Documents, Box 18118, RG 305, National Archives (Pacific Alaska Branch, Seattle (hereinafter referred to as NARA Seattle).

17 "Study of a High Voltage Electrical Interconnection between the Pacific Northwest and California," February 1960, PNW-PSW Intertie Documents, Box 18118, RG 305, NARA Seattle.
} 
strategy to dispose of surplus power in California over COPCO's 230-kv line was still sound:

The study indicates feasibility of an interconnection for the sale of surplus secondary energy in California...sold at delivery points in Oregon for use in Californian markets in the same manner as the Bonneville Power Administration now markets this type of surplus energy for use in Idaho, Montana, and British Columbia. ${ }^{18}$

Significantly, the report also clarified the question over claiming Bonneville's power outside of the Pacific Northwest by public preference customers, noting: "The Regional Solicitor's opinion indicates that preference customers in either the Pacific Northwest or California would have priority in the purchase of both firm and secondary energy over non-preference customers in either area."19

By the time the report was submitted to Congress, Oregon governor Mark Hatfield, Washington governor Albert Rosselini, and California governor Edmund Brown, had been working together for more than a year under the auspices of the Pacific Coast Governors Power Coordinating Committee and had commissioned an intertie study of their own. In order to keep the BPA-COPCO-PG\&E intertie from moving forward, the governors asked the Interior and Insular Affairs Committee in May and June to keep the BPA in check until their own study was concluded and they had been able to work up legislation to limit the preference rights of California's public agencies. As a result, the BPA's sale of surplus power to COPCO was shelved,

\footnotetext{
${ }^{18}$ Ibid.

${ }^{19}$ Ibid.
} 
and the committee requested the Secretary of the Interior to draft a regional preference bill for consideration by members of the Eighty-Seventh Congress in $1961^{20}$

Importantly, the governors' study promoted the viability of a much larger interconnection, using two 500-kv interties to span the distance between the Columbia River and Bakersfield (in Southern California, near Los Angeles). ${ }^{21}$ Furthermore, the study commented favorably on the potential for the use of direct current (DC) lines rather than standard alternating current $(\mathrm{AC})$ technology. ${ }^{22}$ Recent advances in highvoltage DC (HVDC) transmission in Sweden created opportunities for the commercial application of the new technology for the transmission of electricity over long distances. The development of mercury-arc valves in 1939 and silicon-controlled rectifiers (semi-conductors also known as thyristors) in the late 1950s allowed for the development of power lines capable of transmitting DC power hundreds of miles with significantly less line loss than with AC transmission. Because the HVDC lines were also able to use the earth for the return current, savings in power line and tower investments were substantial. When compared to extra-high voltage AC transmission, the longer the HVDC line, the bigger the savings. Those efficiencies were somewhat reduced with the necessary investments into terminal facilities, because HVDC is incompatible for residential and commercial uses unless converted into $\mathrm{AC}$, but as long as transmission lines were planned with few or no turnouts (because each turnout

\footnotetext{
${ }^{20}$ Norwood, Power for the People, $241-242$.

21 The governors' study was conducted by $\mathrm{H}$. Zinder \& Associates, Inc. and submitted in September 1960 , with a revision in January 1961.

${ }^{22}$ Norwood, Power for the People, 241 - 242.
} 
required the construction of expensive terminal facilities), large savings could be gained. $^{23}$

By including Southern California into the intertie study, the governors' study identified far more opportunities for energy exchanges between the regions. The more expansive geography allowed for energy exchanges that would take advantage of the seasonal diversities between the regions and for a larger market area to absorb the BPA's surplus power. For example, increased use in air conditioning and water pumping during Southern California's long, hot summers was beginning to create an annual summer peak in the that region's electrical loads even by the late $1950 \mathrm{~s}$. In comparison, summers in the Northwest were mild, leading to annual lows in power usage at the same time the Columbia River Basin was swollen with snowmelt.

For the Northwest, power usage peaked during the cold winters as people warmed their homes and businesses, but that peak in energy load occurred at the same time the region's power-producing rivers were at their lowest annual water flows. An intertie connecting the two regions would create an opportunity for a seasonally reciprocal exchange of energy, in which the Northwest would transmit hydropower south during the summers and California could send thermal-generated electricity north during the winters.

Furthermore, because the Northwest's power systems were dominated by hydropower plants and Southern California's power systems were reliant on thermal

\footnotetext{
${ }^{23}$ For a thorough and technical evaluation of the advantages and disadvantages of HVDC transmission, see Jos Arrilaga, High Voltage Direct Current Transmission, Second Edition (London, U.K.: Institution of Electrical Engineers, 1998); and K.R. Padiyar, HVDC Power Transmission Systems: Technology and System Interactions (New York: Wiley Press, 1990).
} 
plants, there was an opportunity to rationalize production across both systems on a daily basis as well as a seasonal one. Because hydropower plants can produce energy almost as quickly as it takes to send water through their turbines, they are well designed to supply power during predictable daily peaks in power usage (at breakfast and dinner times). Thermal plants, on the other hand are most efficiently operated when allowed to run at a steady level of output, day in and day out. By connecting the two regions with an intertie, it would become possible to harness the peak power available in the Northwest to assist in the production of peak power throughout the whole system. To reciprocate, thermal plants could return off-peak power north (at night) to allow the region's reservoirs to be recharged for their use in providing peak power the next day.

With the BPA hungry to open up power markets in the state of California, and PG\&E (North America's largest private utility) looking to gain access to the Northwest's grid, it is no surprise that both regional and national attention would become focused on the implications that such interconnections raised. If the Pacific states were to allow their electrical grids to be linked together, just who would finance, construct, own, and operate the interties? Furthermore, how many interties should be built? Where would they be located? How much energy would they transport? And, who would be the primary beneficiaries? Would California's public preference customers be able to gain first call on BPA power? It was the federal government, under the newly elected administration of President John F. Kennedy, that began 
sorting out the answers to these questions through the hands-on involvement of the BPA. 


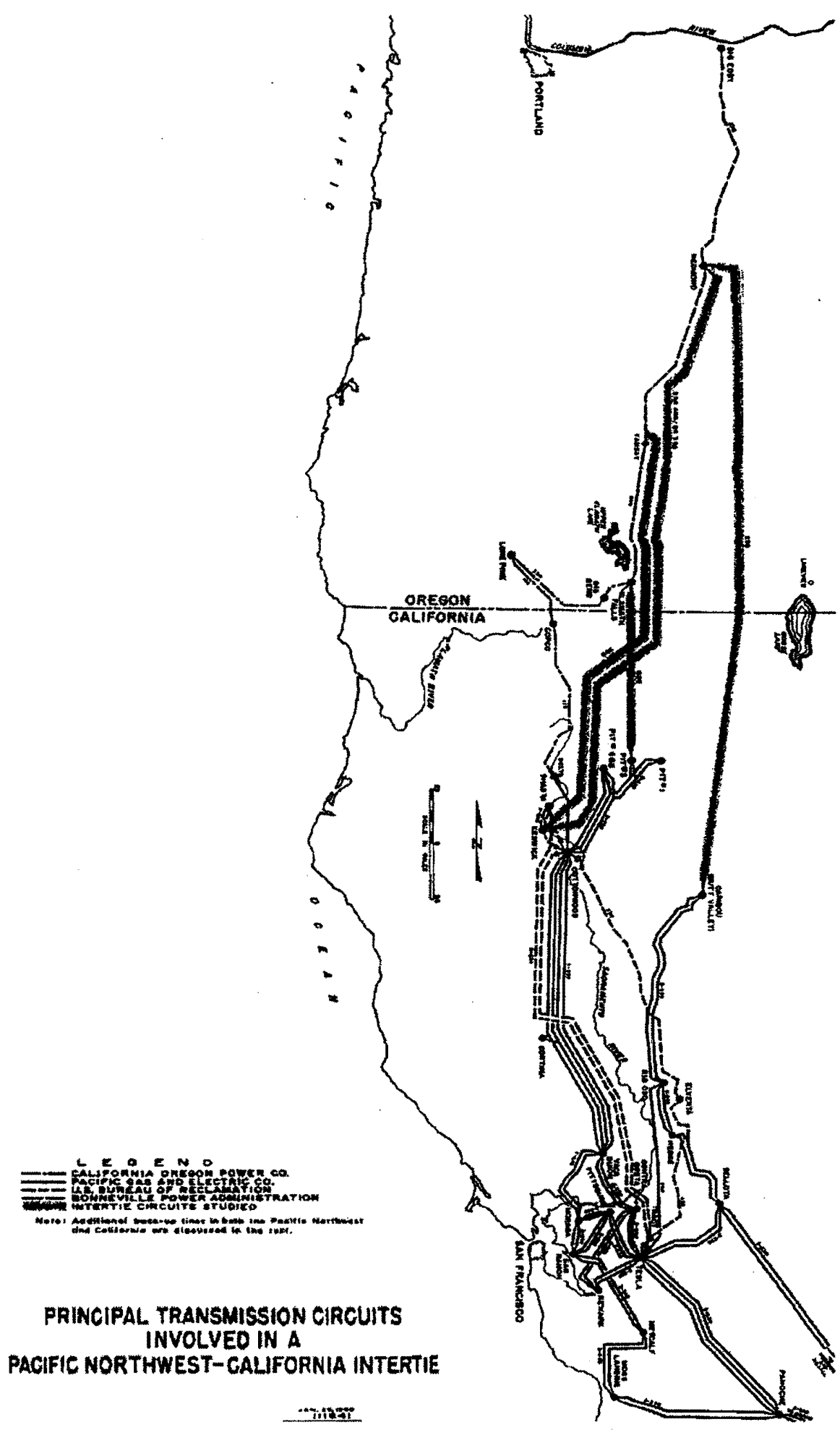

Figure 3: Principle Transmission Circuits Involved in a Pacific Northwest-California Intertie, 1960 


\section{CHAPTER 2: Federal Leadership}

While the BPA was working to expand its markets southward, negotiations between the United States and Canada over the joint-development of the Columbia River, which had begun in 1944, were finally beginning to bear fruit. On January 17 , 1961 , the two countries signed a treaty that paved the way for the construction of three enormous storage dams in Canada and one in Montana. Collectively, these headwater dams promised to double the storage capacity of the Columbia River hydropower system. ${ }^{24}$ The increased upriver storage meant there would eventually be less surplus power for the BPA to market, because the surplus water would be stored in upriver reservoirs and be systematically released to meet needs year-round. Nonetheless, there would be substantial gains in both firm power and peaking power. ${ }^{25}$

The success of the Columbia River Treaty negotiations, along with a welltimed release that same January of California's intertie study, which endorsed the construction of two 500-kv AC interties between the regions, gave President Kennedy good cause to direct Stewart Udall, newly appointed Secretary of the Interior, "to develop plans for the early interconnection of areas served by that Department's marketing agencies with adequate common carrier transmission lines; to plan for

\footnotetext{
${ }^{24}$ Blumm, "The Northwest's Hydroelectric Heritage," $274-275$.

25 "Peaking power" refers to power generated in order to meet peak loads in daily energy uses, typically during breakfast and dinner times.
} 
further national cooperative pooling of electric power, both public and private; and

to enlarge such pooling as now exists. ${ }^{, 26}$

In response to the President's directive, Secretary Udall and Assistant

Secretary Kenneth Holum appointed a five-man task force, with the newly appointed

BPA Administrator, Charles Luce, as its chairman, to study the feasibility of a Pacific

Northwest-Pacific Southwest Intertie and provide recommendations within a year. ${ }^{27}$

Udall gave them six guidelines for the study:

1) Regional interties must be mutually beneficial to both regions;

2) Regional protection legislation and contractual provisions should be enacted and drafted;

3) British Columbia power should be given consideration for the Pacific Intertie;

4) The effect of the Pacific Intertie on fossil fuel use should be taken into consideration;

5) An economic evaluation should be taken into consideration; and

6) Other interties should be studied later and the study should be confined to the Pacific Intertie marketing arreas. ${ }^{28}$

Worried that failure to build an intertie system would force the BPA to raise its rates and stall industrial development across the Northwest, Udall made a point to the task force that they "should consider this work of the very highest priority... and their

\footnotetext{
${ }^{26}$ Memo from Charles Luce and Stewart Udall to All Interested Parties, March 21, 1961, PNW-PSW Intertie (Jan. 1961 to April 1961), Box 18118, RG 305, NARA Seattle.

${ }^{27}$ The appointment of Charles Luce as BPA Administrator signified a shift in BPA priorities beyond the creation of the Pacific Intertie (See Norwood, Power for the People; Springer, Power and the Pacific Northwest; and Tollefson, BPA and the Struggle for Power at Cost). The other members of the task force were Milton A. Chase, General Engineer from the office of the Assistant Secretary of Water and Power Development in Washington, D.C.; Morgan D. Dubrow, Assistant and Chief Engineering Research Advisor to the Assistant Secretary of Water and Power Development; Hugh P. Dugan, Regional Director of the U.S. Bureau of Reclamation's Sacramento office; and Bernard Goldhammer, Power Manager for the BPA in Portland.

${ }^{28}$ Luce and Udall to all interested parties, March 21, 1961, PNW-PSW Intertie (Jan. 1961 to April 1961), Box 18118, RG 305, NARA Seattle. Point No. 6 likely relates to an ongoing investigation by the BPA and Bureau of Reclamation (Region II) to build a Pacific Northwest-Missouri River Basin (east-west) intertie to take advantage of time zone diversities for the supply of peak power.
} 
immediate assistants should spend full time or whatever time is necessary to produce by May 1 a preliminary report."29

The Task Force followed Udall's recommendations closely and quickly began soliciting data from California's water and power agencies, city governments, and public and private utilities for use in their feasibility study. By May 1, they submitted their preliminary report to Udall, recommending "the construction as soon as possible, under government leadership, of full scale test installations of high voltage DC terminal equipment and a substantial length of line."30 If Bonneville was going to commit the federal government's resources toward the construction of a DC intertie potentially bridging almost 900 miles of the Pacific West, it was no surprise that they would want to begin running tests on the reliability of the technology.

By June, the task force also began distributing a draft of a regional preference bill to all of the BPA's customers, the public and private utilities in California, governors of the Pacific Coast states, appropriate state agencies, and other interested groups such as chambers of commerce and trade and industrial associations.

Essentially, the early drafts defined the "Pacific Northwest" as:

the states of Oregon and Washington, the State of Montana west of the Continental Divide, and such portions of the States of Nevada, Utah, and Wyoming within the Columbia drainage basin and of the State of Idaho as may be determined by the Secretary of the Interior to be

\footnotetext{
${ }^{29}$ Memo from Stewart Udall to Kenneth Holum, Charles Luce, Floyd Dominy, and John Kelly, March 24, 1961, PNW-PSW Intertie (Jan. 1961 to April 1961), Box 18118, RG 305, NARA Seattle. Udall also asked that the task force draft a regional preference bill and circulate it for comment. ${ }^{30}$ Intertie Task Force, "Progress Report of May 1, 1961, Pacific Northwest-Pacific Southwest Interconnection," 3, PNW-PSW Intertie Documents, Box 18118, RG 305, NARA Seattle.
} 
within the marketing area of the Federal Columbia River power system. ${ }^{31}$

Although the core text of the bill addresses the sale of "surplus power" potentially available from the region's hydropower plants, the wording of the bill —even in the title-specifically identifies the power in question as "electrical power or energy of any kind generated at Federal plants in the Pacific Northwest for use outside of...the Pacific Northwest" as being subject to its provisions. Additionally, the bill forwarded a principle of reciprocal returns, in which

surplus electric energy generated at Federal plants in the Pacific Northwest which can be conserved... may be sold or exchanged on a provisional basis under contracts providing...the purchaser will return the full amount of energy delivered to him...including transmission and head losses, as may be required for use within the Pacific Northwest. ${ }^{32}$

In the cover letters that accompanied the regional preference drafts, Luce also included a boilerplate paragraph that made sure to highlight the fact that this legislation was in no way intended to expand Bonneville's marketing boundaries. In fact, as of 1961, there were no specified geographical boundaries to BPA's marketing of power, something Luce made sure each reader of the bill understood at the onset. Specifically, he pointed out:

One thing should be clearly understood about the enclosed draft of legislation: It does not enlarge the present authority of Bonneville to market electrical energy outside the Pacific Northwest. To the contrary, it substantially restricts our present authority. Under existing

${ }^{31}$ A Bill to guarantee consumers in the Pacific Northwest first call on electric energy generated at Federal plants in that region, Draft dated June 26, 1961, PNW-PSW Intertie (May 1961 - June 1961), Box 18118, RG 305, NARA Seattle.

${ }^{32} \mathrm{Ibid}$. The regional preference draft explicitly exempted any Canadian power stemming from the Columbia River Treaty from the provisions of the bill. 
Federal law, Bonneville has authority to market power to anyone, with preference to public agencies and cooperatives, any where within economic transmission distance. ${ }^{33}$

Luce also routinely pointed out to interested parties in the Northwest that regardless of whether or not any such legislation were passed, more interconnections, such as the then-suspended line between PG\&E and COPCO, could be expected in the future. ${ }^{34}$ In response to the task force's call for comments, more than thirty-five parties responded. For the most part, Northwestern groups were in favor of the need for such legislation, even if they recommended revisions. There were Northwestern groups that opposed the need for preference legislation, but they were usually against the whole idea of any power transfers out of the Northwest at all. The Washington State Sportsman Council, for example, passed a formal resolution against the Pacific Intertie, worried that increased pressure by electrical customers from beyond the region, particularly in California, would make conditions for the region's already decimated salmon populations even worse. ${ }^{35}$ The Snohomish Tribes, which formally and unanimously endorsed the resolution of the Washington State Sportsman Council, also protested the construction of the intertie system in a June 9 letter to Udall:

Whereas we Indians feel we have too many power dams blocking our streams to migratory salmon and such an intertie will eventually call for more dams as increased demand for more power in the future. We feel that no such power intertie contract or agreement should be entered into without a guarantee that no further power dams be built. However, we feel that power generated by coal mined from our local mines could be

\footnotetext{
${ }^{33}$ For copies of relevant correspondence see multiple letters sent by Charles Luce to various interested parties during early June, PNW-PSW Intertie (May 1961 to June 1961), Box 18118, RG 305, NARA Seattle.

${ }^{34}$ Ibid.

${ }^{35}$ Hank Hawkins, Snohomish Tribe of Indians, to Stewart Udall, June 9, 1961, PNW-PSW Intertie (May 1961 to June 1961), Box 18118, RG 305, NARA Seattle.
} 
used for this proposed Intertie that we Indians still feel that we should have a guarantee that no more power dams shall be built. ${ }^{36}$

Udall assured them that "the Interior Department has launched a crash program of fishery research to determine the effect of dams on the fishery resource." ${ }^{37}$

Luce responded to what appeared to be a minority of opposition in the Northwest by reminding them that PG\&E had already been working on a plan to connect their power grid with the BPA's along the Oregon-California border. He then raised the possibility of a public utility or a power-hungry municipality like Los Angeles gaining access to the Northwest's hydropower as a preference customer. Luce reminded them that Bonneville was committed to helping protect the interests of the Northwest with some form of regional preference before constructing any interties. But, he warned detractors that "Interties are here to stay-either we in the Pacific Northwest must devise a way to take advantage of interties, or interties will take advantage of us." 38

Comments on the preference bill from interested parties in California were mixed, and many comments focused primarily upon the Intertie itself and much less so on the regional preference draft bill. Some respondents, like the Merced Irrigation District, worried that the sale of the BPA's surplus power would only delay "much needed water development" in the state. They were "opposed to the importation of

\footnotetext{
${ }^{36}$ Snohomish Tribe of Indians to Stewart Udall, June 9, 1961, PNW-PSW Intertie (May 1961 to June 1961), Box 18118, RG 305, NARA Seattle.

${ }^{37}$ Udall to Hawkins, July 12, 1961, PNW-PSW Intertie (May 1961 to June 1961), Box 18118, RG 305, NARA Seattle. The "crash program" must have been in reference to the federal hatchery program.

${ }^{38}$ Summary Statement by Charles F. Luce, Bonneville Power Administrator, of remarks before California Intertie Panel at Annual Convention of Inland Empire Waterways Association, Spokane, Washington, Oct. 24, 1961, PNW-PSW Intertie (Sept. 1961 to Dec. 1961), Box 18118, RG 305, NARA Seattle.
} 
electric power that would compete with the power we are now selling and propose to sell to support our water development projects. ${ }^{\text {"39 }}$ Other groups-most notably the Northern California Municipal Electric Association, the Los Angeles Department of Water and Power, and the California Department of Water Resources-pointed out that regional preference should only be given to power generated from the Northwest's hydropower plants, not to thermal or non-federally produced power. They also felt that the bill did not treat the two regions equitably and that the requirements to return power during off-peak hours wholly excluded non-power producing agencies from participating altogether, even though they might be interested in purchasing peak power. ${ }^{40}$ California's Department of Water Resources also pointed out that "state boundaries should not be permitted to form a bar to sensible and economic utilization of electric energy resources." ${ }^{.41}$

Still, California's public power agencies were most definitely interested in obtaining available power from the Northwest and were attracted to the promise a larger marketing area for power generated from their own power plants. For example, California's Department of Water Resources noted that they would like to be able to market electricity from their Oroville plant in the Southern California energy market.

\footnotetext{
${ }^{39}$ Kenneth R. McSwain, Merced Irrigation District, to Bernard Goldhammer, July 6, 1961, PNW-PSW Intertie (May 1961 to June 1961), Box 18118, RG 305, NARA Seattle.

${ }^{40}$ See David Koester, President of Northern California Municipal Electric Association, to Charles Luce, July 21, 1961; Ivan Bateman, Chief Electrical Engineer and Assistant Manager, Los Angeles Water and Power, to R.C. Price, Acting Director, California Department of Water Resources, July 21, 1961; and R.C. Price, to Charles Luce, July 21, 1961; all in PNW-PSW Intertie (July 1961 - Aug. 1961), Box 18118, RG 305, NARA Seattle. SMUD, for example, would have had to build its own thermal plant to participate in the power exchanges proposed by the BPA-unless they were able to draft a workable arrangement with PG\&E to return energy associated with peaking capacity.

${ }^{41}$ Price to Luce, July 21, 1961, PNW-PSW Intertie (July 1961 - Aug. 1961), Box 18118, RG 305, NARA Seattle.
} 
Although there was some interest for both peak and firm power by various public agencies across California, the Sacramento Municipal Utility District (SMUD) and L.A.'s Department of Water and Power (two of the state's biggest public power brokers) specifically stated that they would primarily be interested in an arrangement that allowed them to import Northwestern power during the summer months for an equitable return of power during the winter months. And, while they were interested in the delivery of some peak power, they were especially interested in the opportunity to add more firm power to their systems. ${ }^{42}$

The private utilities in California were much less enthused about the idea of the federal government building any extra-high-voltage power lines across their own marketing territories. Three of the state's largest electrical companies-San Diego Gas and Electric, California Electric Power, and Southern California Edisonsubmitted a joint letter in response to the BPA's call for comment that argued for the abandonment of the Pacific Intertie endeavor altogether, stating:

In view of the uncertain and speculative nature of the premises involved, and based upon our experience in the electric utility business, at the present time we do not believe it is possible to arrive at a favorable cost-benefit ratio for a twin-circuit EHV [Extra-HighVoltage] transmission line between the Northwest and California which would survive an objective engineering analysis. ${ }^{43}$

And as far as the regional preference draft was concerned, the companies believed:

\footnotetext{
${ }^{42}$ William Warne, Director, California Department of Water Resources, to Bernard Goldhammer, Aug. 7, 1961; Conference report from Bernard Goldhammer to Charles Luce regarding Aug. 7, 1961 meeting in San Francisco with preference customers of California; Aug. 16; both from PNW-PSW Intertie (July 1961 - Aug. 1961), Box 18118, RG 305, NARA Seattle.

${ }^{43}$ Presidents of Southern California Edison Company, San Diego Gas \& Electric Company, and California Electric Power Company, to Charles Luce, Sept. 22, 1961, PNW-PSW Intertie (Sept. 1961 Dec. 1961), Box 18118, RG 305, NARA Seattle.
} 
Protective legislation proposed by the Northwest would subject export of firm power to relatively short notices of withdrawal [stated in the draft as seven days], which would seriously limit the effective life of the large investment in the proposed tie line as a source of prospective firm power for California. ${ }^{44}$

California's private power companies did not want any federal intrusion into their marketing territories. Regardless of how well the regional preference draft was written, their ideological opposition to a federal intertie would not change. In their efforts to derail the federal government's plans to authorize and fund a publicly owned transmission system that crossed through their territories, California's private utilities began pooling power across their own systems. In the process, they started to create a more integrated electrical grid for the state, one they hoped would nullify the justification for any federally constructed intertie. But, if they were to blunt the efforts of the Department of Interior to build a federally owned intertie across California, they would have to establish plans for an intertie system that were on par with what the Luce's Intertie Task Force was in the process of developing in 1961.

${ }^{44}$ Ibid. 


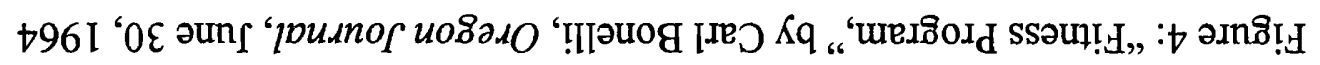

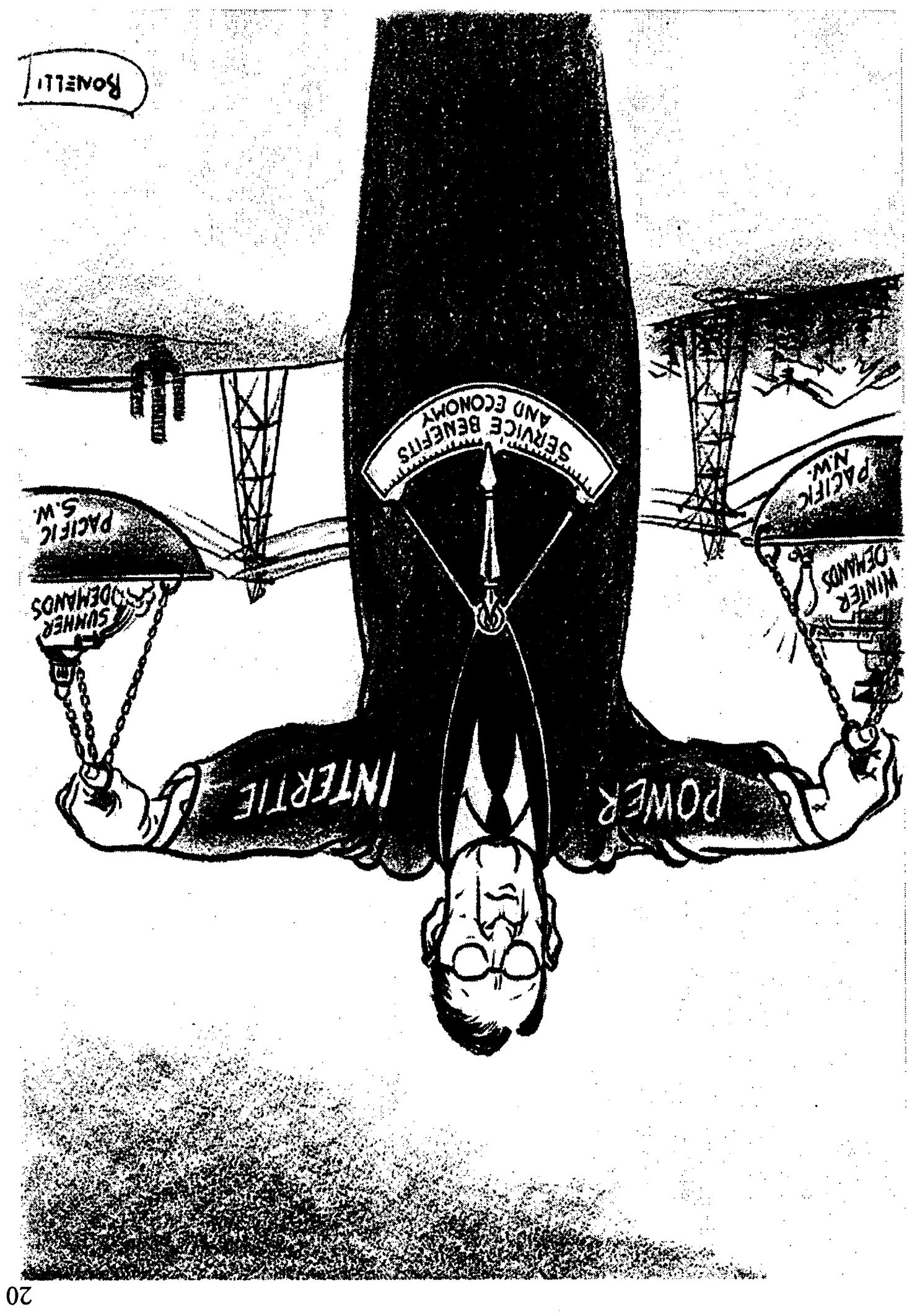




\section{CHAPTER 3: The Federal Yardstick}

In mid-December 1961, Luce's task force submitted its completed intertie report to Secretary Udall, concluding that the Pacific Intertie would be "such a good deal for the Northwest that the protective legislation should be passed and an Intertie constructed as quickly as possible." Through its report, the task force demonstrated their willingness to move forward on the project regardless of stated opposition from California's private electrical companies. The report subsequently called for the construction of an initial 750-kv DC connection stretching from The Dalles Dam on the Columbia River, through Tracy, California, to Los Angeles, with the capacity to deliver between 650,000 and 900,000 kilowatts $(\mathrm{kw})$. Importantly, the task force pointed out that this recommendation was feasible even without the participation of private utilities in any energy exchanges, and was designed specifically to provide California's public agencies with power. ${ }^{45}$ If, however, California's private utilities decided to participate in the operation of the Pacific Intertie, then "the task force recommended there be two d-c lines, or two $500 \mathrm{kv}$ a-c lines, or three $345 \mathrm{kv}$ a-c lines, in that order of preference." Additionally, if both the public and private power interests in California decided to participate and Canada agreed to sell their treatybased power over the intertie, "the task force recommended, first, three d-c lines and, second, three $500 \mathrm{kv}$ a-c lines... with a capacity of about 2,500,000 kw."

\footnotetext{
${ }^{45}$ Teletype from Charles Luce to George Toman, BPA Assistant Manager, Washington, D.C. office (regarding press release for Dec. 20), Dec. 18, 1961, PNW-PSW Intertie (Sept. 1961 - Dec. 1961), Box 18118, RG 305, NARA Seattle.

${ }^{46}$ Ibid.
} 
The creation of a formal plan for a federally constructed Pacific Intertie

would serve as a yardstick for the evaluation of all proposals in economic costs and engineering efficiencies that would eventually be submitted to the Intertie Task Force for consideration. ${ }^{47}$ Immediately, however, the federal yardstick established considerable leverage to move all non-federal parties into meaningful negotiations with the BPA; otherwise, the private utilities risked the chance of having the federal plan imposed on their territories. The disincentive for not participating was greater than the risks associated with compromises likely to result from a public-private partnership in the planning, construction, operation, and control of the intertie.

The federal government's commitment to the construction of at least one DC leg of the Pacific Intertie, in part, demonstrates the importance placed on the development of the nation's energy infrastructure during the Cold War. ${ }^{48}$ The Soviets had already undertaken an effort to build a 300-mile-long HVDC intertie. ${ }^{49}$ The United States was poised to do better. A DC line stretching almost 800 miles would demonstrate to the world that that Americans were superior in DC transmission. Even more, Udall believed that DC technology held "exciting promise" on the domestic

\footnotetext{
${ }^{47}$ The yardstick principle was established during the administration of President Franklin D. Roosevelt and made public in a speech delivered in Portland, Oregon, on September 21, 1932. See Ogden, "The Development of Federal Power Policy in the Pacific Northwest," 146.

${ }^{48}$ Evidence of Soviet-American competition in the field of long-distance electrical transmission surfaces repeatedly throughout the negotiations related to the construction of the Pacific Intertie system (at local, regional, national, and international levels) and could be the focus of an independent historical analysis. It is highly likely that future scholarship on the creation of the Intertie will determine that the integration of high voltage direct current technology into the western grid was directly related to technological competition with the Soviets. Regardless, attention to the Cold War nexus of politics, ideology, science, and technology has subsequently been avoided in this thesis.

${ }^{49}$ Charles Luce to W. A. Van Allen, Apr. 4, 1962, PNW-PSW Intertie (Apr. 1962 - Dec. 1962), Box 18118, RG 305, NARA Seattle. According to Luce, the Soviet's Stalingrad-Donbass line was likely "a prototype installation to develop and refine the terminal equipment and d-c transmission techniques."
} 
front as well, foreseeing the potential for the Pacific states and the Missouri River Basin to tap the hydropower potential of Alaska and the Yukon, for the cities of New York, Philadelphia, and Boston to benefit from interties linking them directly to mines in Pennsylvania and West Virginia, and for Detroit and Chicago to gain similar benefits from DC interties connecting those cities to mines in North Dakota and Montana. $^{50}$

All told, there were eight alternative transmission plans included in the task force's report on the Pacific Intertie. According to Luce, "In addition to being selfliquidating [over its fifty-year lifespan] and producing a profit for BPA, the Intertie would permit savings in plant investment in the two regions greater than the cost of the lines." For the BPA's grid, the intertie would not only provide a market for the sale of a considerable amount of secondary power, but also promise the availability of even a modest amount of thermal power (estimated at roughly $23,000 \mathrm{kw}$ during the "early years") from the Southwest to firm up a large amount of power (approximately $400,000 \mathrm{kw})$ in the Northwest. ${ }^{51}$

The Intertie Task Force was convinced that the exchange of power between the regions was a winning proposition all around. Not only would each region be able to save an estimated $\$ 90$ million on plant investments to provide for future peak power needs, but the intertie would also pay for itself and even provide a profit for the BPA, which would help it pay down the debt accrued during the construction of the

\footnotetext{
${ }^{50}$ Teletype from Luce to Toman, Dec. 11, 1961, PNW-PSW Intertie (Sept. 1961 - Dec. 1961), Box 18118, RG 305, NARA Seattle.

${ }^{51}$ Teletype from Luce to Toman, Dec. 18, 1961, PNW-PSW Intertie (Sept. 1961 - Dec. 1961), Box 18118, RG 305, NARA Seattle.
} 
Columbia River hydrosystem. Even so, the task force recommended that Congress only appropriate funds "for the designing and planning of the intertie during the following year and delay the appropriation of construction funds until Congress was able to pass a regional preference bill., ${ }^{, 52}$

Not surprisingly, California's private utilities were less enthusiastic about the report. Southern California Edison immediately issued a response to the press stating that the project was absolutely unnecessary because the state's private utilities had already devised a plan to build their own intertie without any investment by the nation's taxpayers. ${ }^{53}$ Within weeks of the task force's report, California's private utilities also announced the formation of the "California Power Pool," which combined the resources of PG\&E, San Diego Gas and Electric, California Electric Power, and Southern California Edison into a unified voice of opposition against a publicly owned and operated intertie system. In addition to their intent to defeat any Congressional approval for a federal intertie, the California Power Pool also announced their decision to submit a proposal to the BPA for a more viable alternative involving the construction of privately owned and operated intertie lines in California. $^{54}$

\footnotetext{
${ }^{52}$ Ibid.

${ }^{53}$ W.A. Van Allen to Charles Luce, March 13, 1962, PNW-PSW Intertie (Jan. 1962 - Mar. 1962), Box 18118, RG 305, NARA Seattle.

54 "Third Northwest Line to Strengthen Power Interchange: 4 Utilities Sign Statewide Power Pool Pact," PG\&E Progress 29:2 (Feb. 1962): 1, in PNW-PSW Intertie (Jan. 1962 - Mar. 1962), Box 18118, RG 305, NARA Seattle. The three lines noted in the title of the article refer to the proposed PG\&EPP\&L line, an existing 220-kv line between PG\&E and Southern California Edison, and a 500-kv line being studied by the newly formed California Power Pool. During the course of the negotiations over the Pacific Intertie, the California Power Company was bought out by Southern California Edison (officially merged on January 1,1964 ).
} 
On January 5, 1962, soon after the California Power Pool announced it would be devising its own intertie proposal, PG\&E and Pacific Power and Light (PP\&L) - the Northwestern electrical company that merged with COPCO in 1961signed a contract indicating that they would continue moving forward with plans to interconnect their electrical systems across the Oregon-California border, regardless of political opposition to the BPA's sale of electricity out of the region. PG\&E even attempted to revive negotiations with the BPA over the purchase of secondary energy via the lines of PP\&L and the yet-to-be built AC line crossing the state line to PG\&E's facilities at Round Mountain in California. BPA Administrator Charles Luce quickly indicated that, while he was willing to discuss the terms for the transfer of energy between the two systems, he "could make no commitment until Congress had acted upon the regional preference legislation." ${ }^{25}$ Once the contract between the two private utilities was made official, the BPA "indicated publicly that [while] this line could serve as one of the several proposed...it does not eliminate the need for the other lines recommended in the report.",56

The private utilities' efforts to create a "small" 110-mile intertie between their systems continued to be fought over throughout the remainder of the year. By January 1963, the U.S. Forest Service, which had delayed the construction process through a year-long environmental impact study, had denied the companies' application for right-of-way. Additionally, the regional office of the Forest Service in San Francisco

\footnotetext{
${ }^{55}$ Memo from Charles Luce to Assistant Secretary for Water and Power, Jan. 18, 1962, PNW-PSW Intertie (Jan. 1962 - Mar. 1962), Box 18118, RG 305, NARA Seattle.

${ }^{56}$ Warren Marple, BPA Program Coordinator, to Carl Miller, Feb. 26, 1962, PNW-PSW Intertie (Jan. 1962 - Mar. 1962), Box 18118, RG 305, NARA Seattle.
} 
recommended that the "request be approved for an alternate route farther to the east... paralleling an existing natural gas pipeline. ${ }^{, 57}$ Importantly, this delay and eventual denial of right-of-way and the resulting delays in construction of the privately built and operated intertie between the regions helped strengthen the BPA's leverage for ongoing Pacific Intertie negotiations through 1962 and into 1963. Had PG\&E been able to begin transferring power between regions in 1963, the economic feasibility of the federal intertie program would have certainly have been diminished. An existing privately controlled intertie would not only have unloaded some power from the publicly-owned lines, which would have affected the repayment of accrued debts in their construction and operation, but it would have also set a strong precedent for the private construction and operation of other proposed intertie lines. The line may have also placed PG\&E in the powerful position of electrical toll-gate operator, something Luce did not want because "most of the profits from such an intertie would accrue to the private utility rather than to Bonneville and the United States Treasury." $\$ 8$

While the drama over the building of the 110-mile privately owned intertie played on, the BPA continued to work with the rest of the parties interested in constructing portions of the Pacific Intertie system, essentially as it had been envisioned in the December 1961 Task Force Report. During the remainder of 1963, interested parties began consulting with the BPA in earnest to craft proposals to build

\footnotetext{
${ }^{57}$ Warren Marple to Charles Luce, conference report regarding Jan. 16, 1963 meeting with Forest Service, San Francisco Office, Jan. 17, 1963, PNW-PSW Intertie (Jan. 1963 - Mar. 1963), Box 18119, RG 305, NARA Seattle.

${ }^{58}$ Luce to Van Allen, April 4, 1962, PNW-PSW Intertie (Apr. 1962 - Dec. 1962), Box 18118, RG 305, NARA Seattle.
} 
and operate individual portions of the system. The first party to officially submit a proposal to the BPA (on December 28, 1962) was the Maryland-based International Utilities. Their involvement in the Pacific Intertie grew from considerable subsidiary interests in Western Canada's gas and electric systems. According to International Utilities' vice president, John M. Seabrook, "a strong direct tie between the Colorado River, the Columbia River, and eventually the Peace River would have all sorts of advantages." The biggest advantage for International Utilities was, of course, being able to profit from power transferred between Western Canada and the Western United States, particularly the energy markets of Southern California. ${ }^{59}$

International Utilities submitted a proposal to construct a DC intertie that would stretch from The Dalles through Nevada to Southern California. They were committed to privately financing the DC intertie and using it to transport power between buyers and sellers on each end of the line. According to their proposal, "International Utilities would merely transport, for a charge under a contract for line capacity, power which had been sold and purchased by others....We would consider giving the contractors the right to purchase the line after an agreed upon period." The cost to parties using the line was left fairly vague in their original proposal, only indicating "charges set forth in the contract would be based upon the revenue requirements of International Utilities."

\footnotetext{
${ }^{59}$ John Seabrook, Vice President of International Utilities, to Charles Luce, Jan. 24, 1963, PNW-PSW Intertie (Jan. 1963 - Mar. 1963), Box 18119, RG 305, NARA Seattle.

${ }^{60}$ Seabrook to Luce, Dec. 28, 1963, PNW-PSW Intertie (Jan. 1963 - Mar. 1963), Box 18119, RG 305, NARA Seattle.
} 
The next proposal, submitted to the BPA (on January 11,1963) was from the California Power Pool. According to the Power Pool, they were in an ideal position to construct any portion of the Pacific Intertie that crossed California soil because their member companies "own and operate nearly three million kilowatts of hydroelectric generating capacity and ten million kilowatts of thermal electric generating capacity. This is approximately $65 \%$ of the hydro and $80 \%$ of the thermal capacity in California." ${ }^{\text {61 }}$ The Power Pool proposed to build two extra-high voltage (EHV) AC transmission lines (at $500 \mathrm{kv}$ each), in stages, stretching southward 650 miles from PG\&E's Round Mountain facilities in Northern California. Their construction schedule indicated that the first of their AC interties would reach PG\&E's Feather River lines by 1965, the San Francisco Bay area by 1966, and the Los Angeles area by 1967 . As the line was extended, its operating capacity would increase in step, with the companies able to draw $400,000,600,000$, and $900,000 \mathrm{kw}$ respectively at each phase in construction. Importantly, the proposal called for the BPA to sell all power being transferred over the intertie directly to Power Pool members at the California state line. They claimed "such sale of Bonneville power to Pool members will prevent any preference rights to Bonneville power from extending south of the border. This will eliminate any need for the proposed Northwest protective legislation which was before Congress in 1962." As to costs, the Power Pool committed itself to charging public agencies within California the same rate that the BPA would charge

\footnotetext{
${ }^{61}$ Robert Gerdes (Executive Vice President of PG\&E), J.K. Horton (President of Southern California Edison), H.D. Dillin (President of San Diego Gas \& Electric), and Fred Oldendorf, Jr. (President of California Electric Power Company), to Charles Luce, Jan. 11, 1963, PNW-PSW Intertie (Jan. 1963 Mar. 1963), Box 18119, RG 305, NARA Seattle.
} 
over a federal intertie, "with appropriate adjustment for any agreed upon support provided by Pool members."

The Power Pool detailed seven advantages that their privately constructed and operated system would have over a federal intertie. These arguments were similarly outlined in a January 14 press release titled "Utilities Offer Plan to Save U.S. Millions," and they were no doubt used time and again in their lobbying efforts at local, state, regional, and federal levels.

1. The Federal Government would save capital outlay of not less than $\$ 100$ million and up to $\$ 245$ million for transmission and substation facilities in California;

2. Federal, state, and local tax revenues would be increased by at least $\$ 110$ million during the 20-year contract period;

3. Virtually all the California power market would be made available for disposal of surplus Northwest power;

4. Revenues from sales of surplus power to California would accrue to Bonneville at a much earlier date and be available in maximum amounts to reduce Bonneville deficits;

5. Northwest power consumers would be protected in their use of Bonneville power without the necessity for enactment of the controversial Northwest protective legislation;

6. The California Water Plan and the participation of local public agencies in California would benefit from the support of the combined generation and transmission systems of the California Power Pool; and

7. More complete integration of power resources within California and better coordination between electric systems in both regions would assure the lowest cost to power consumers and taxpayers. ${ }^{63}$

A third proposal was submitted to the BPA by Oregon-based Portland General Electric (PGE) on January 28. Under this proposal, PGE offered to build a 180-mile portion of a 500-kv AC line that stretched between their Round Butte hydropower

\footnotetext{
${ }^{62} \mathrm{Ibid}$. The Round Mountain station was the intended southern terminal for the 110-mile intertie already contracted for construction by PG\&E and PP\&L across the California-Oregon border. ${ }^{63} \mathrm{Ibid}$.
} 
project on the Deschutes River to a yet-to-be-built PP\&L substation east of Klamath Falls, the northern terminus of the proposed 110-mile PG\&E and PP\&L line. PGE indicated that it "would make available to the BPA one-half of the capacity of this line for $\$ 865,000$ per year, which we estimate would be BPA's cost under Federal construction and operation."

Washington's Grant County Public Utility District (PUD) also submitted a proposal to the BPA on January 28. Not providing any specific details, the Grant County PUD seemed to be putting their hat into the ring in case plans for the Pacific Intertie were expanded to include a tie line in the state of Washington. According to their proposal, "this district wishes to propose that it will construct, individually or in conjunction with other public agencies, that portion of the $\mathrm{AC}$ or $\mathrm{DC}$ transmission line or lines in the State of Washington, together with the necessary terminal facilities at the suitable point of interconnection with the Bonneville System." ${ }^{.65}$

The next proposal to build a portion of the Pacific Intertie was submitted by Northwest Intertie, Inc., an Oregon-based non-profit corporation formed ín April 1962 and owned by rural electrical cooperatives. Northwest Intertie believed it could build a DC leg of the Pacific Intertie that stretched from the Columbia River (likely from the proposed John Day Dam) to Los Angles for an estimated cost of $\$ 60$ million, but this price did not include any of the costs associated with the installation of terminal facilities at either end of the line. If either the BPA or city of Los Angeles did not

\footnotetext{
${ }^{64}$ Frank Warren, President of PGE, to Charles Luce, Jan. 28, 1963, PNW-PSW Intertie (Jan. 1963 Mar. 1963), Box 18119, RG 305, NARA Seattle.

${ }_{65}$ Bernard Goldhammer to All BPA Customers, Feb. 1, 1963, PNW-PSW Intertie (Jan. 1963 - Mar. 1963), Box 18119, RG 305, NARA Seattle. Since no tie lines were constructed in Washington as part of the formal plans for the Pacific Intertie, this proposal was essentially shelved and not revisited.
} 
wish to build the necessary terminals, for any reason, then Northwest Intertie

offered to construct them for an estimated cost of $\$ 30$ million each. The route for their proposed line crossed central Oregon, northwestern Nevada, and then entered California through the Owens Valley before continuing south to Los Angeles. As the second proposal submitted for construction of a DC line, their plan stood as direct competition for the offer by International Utilities. ${ }^{66}$

While Northwest Utilities was certainly interested in assuring that the West's electrical cooperatives and publicly owned utilities were directly served by power over the Pacific Intertie, the rhetoric of their proposal was couched in the language of the Cold War. Promising to operate the intertie "without profit and in the public interest," they believed the project provided "an effective challenge to the Communist bid for supremacy in the development of high voltage long distance direct current transmission of electricity." ${ }^{97}$ According to their president, Ivan C. Laird: Electric transmission is one of the prime tools of industrial and military strength. There could be no better method for meeting the Soviet challenge than a joint effort by the Federal Government, the largest municipal electric system in the United States and a private corporation that represents over 75,000 of the most dedicated exponents of free enterprise and individual initiative in the free world. ${ }^{68}$

The sixth and final proposal submitted to the BPA (on January 31, 1963) was from PP\&L. By then, their plans to build a 110-mile stretch of intertie in conjunction with PG\&E were already familiar to the BPA, having been an ongoing affair for five years. Still, their proposal formally integrated the original flash-point of controversy

\footnotetext{
${ }^{66}$ Ivan Laird, President of Northwest Intertie, to Charles Luce, Jan. 31, 1963, PNW-PSW Intertie (Jan. 1963 - Mar. 1963), Box 18119, RG 305, NARA Seattle.

${ }^{67}$ Ibid.

${ }^{68}$ Ibid.
} 
over the interconnection of the electrical systems of the Pacific Northwest and

California into the planning for the Pacific Intertie. While the two companies were moving forward with the expectation that their intertie connection would initially be limited to a 230-kv AC intertie, their plans were to construct it so that the line could be operated at $500 \mathrm{kv}$ in the near future. ${ }^{69}$

Once the proposals were all in hand, the BPA began drafting contracts with each of the six interested parties in order to obtain more detailed information about the construction and operation of each proposed portion of the Pacific Intertie system. ${ }^{70}$ Through the process of contract negotiations, the BPA expected to gain a much more reliable idea of each plan. Once the drafts were completed—and the advantages, disadvantages, and costs were clarified-each proposal would then be compared to the federal yardstick. Luce and his staff made the negotiation of contracts a high priority in order to help prepare for House appropriation hearings scheduled for April $1963 .^{71}$

As the contract negotiations got underway, the BPA also received word that Arizona's utilities were interested in the idea of a second DC leg of the intertie that would directly connect Hoover Dam to the Pacific Northwest's grid, likely at a terminal located near The Dalles or John Day dams. In order to determine whether

\footnotetext{
${ }^{69}$ E. Robert De Luccia, Vice-President and Chief Engineer of PP\&L, to Charles Luce, Jan. 31, 1963, PNW-PSW Intertie (Jan. 1963 - Mar. 1963), Box 18119, RG 305, NARA Seattle.

${ }^{70}$ One more (informal) proposal was received by the BPA in February. It was submitted by Harvey Aluminum, a California-based company (with a plant in The Dalles, Oregon) primarily interested in building the DC line for an unspecified engineering fee and what seemed to be an arrangement that would allow them to provide all the aluminum for the poles and wires. The Harvey Aluminum proposal was not seriously considered by the Intertie Task Force in 1963.

${ }^{71}$ Minutes of Administrator's staff meetings, Volume 4: 1963 - 1964, Feb. 6, 1963, Library of the Bonneville Power Administration, Portland, Oreg. (hereinafter referred to as BPA Library); Charles Luce to Assistant Secretary of Water and Power, Feb. 5, 1963, PNW-PSW Intertie (Jan. 1963 - Mar. 1963), Box 18119, RG 305, NARA Seattle. The Sacramento and Denver offices of the Bureau of Reclamation worked with the BPA in the evaluation and drafting of the contracts.
} 
this second DC intertie was both technically and economically feasible, Luce assigned BPA Power Manager Bernard Goldhammer with the task of studying the power needs and transmission capabilities of Arizona's utilities and electrical infrastructure. Luce also recommended to Assistant Secretary Holum that the BPA and Bureau of Reclamation "make a more intensive survey of the power markets in Nevada and Arizona," reasoning that subsequent studies might be used to formulate a formal proposal to Congress "that a Nevada routing be chosen for the EHV DC line in lieu of the routing suggested in the 1964 budget presentation of the Bonneville Power Administration and the Bureau of Reclamation." 72

By the early months of 1963 , the federal government, largely through the hands-on leadership of Luce, had done much to lay the groundwork for the creation of the Pacific Intertie. During 1961, following the orders of President Kennedy and Secretary Udall, the BPA's task force circulated drafts of regional preference legislation, making amendments to it as comments were received from interested parties across the American West. By starting the process of working out the language and gaining support for a regional preference bill early, the BPA won over most of its customers in the Pacific Northwest. The early and wide distribution also helped raise the BPA's credibility among various Californian interests as well. As the planning for the Pacific Intertie continued to move forward, the BPA's continued insistence that the construction of the intertie system was politically dependent on the passage of some form of regional preference helped provide an incentive for all parties to work toward

\footnotetext{
${ }^{72}$ Kenneth Holum to Stewart Udall, Feb. 6, 1963, PNW-PSW Intertie (Jan. 1963 - Mar. 1963), Box 18119, RG 305, NARA Seattle.
} 
compromise for regional protection. As it became more likely that a wealth of Canadian power (resulting from the Columbia River Treaty) might become available to the American West, the pressure to compromise on the regional preference bill increased.

When the Intertie Task Force released its December 1961 report promoting the technological and economical feasibility of a federally constructed Pacific Intertie, the BPA established a federal yardstick by which all other intertie proposals would be compared. In the subsequent negotiations with the California Power Pool, which derided the idea of federally owned interties across their marketing territories, the federal yardstick became a powerful tool for the BPA. The yardstick's effects were immediately visible in California, as the state's private utilities coordinated their efforts to blunt the threat of federal intrusion. Initially, the federal plan gave cause for California's private utilities to integrate their electrical systems more fully.

Secondarily, the yardstick forced the Power Pool to propose their own plan to construct and operate a north-south intertie system that operated to the benefit of both private and public interests alike-something likely not to have happened if not for the federal threat.

Still, the effort to build the Pacific Intertie was strikingly different than the massive energy projects of the New Deal era. The onset of the Cold War had given political capital to proponents of the free market system and critics of federal ownership of any of the nation's non-governmental infrastructure. As the planning for the Pacific Intertie moved forward, both President Kennedy and members of 
Congress required the BPA to demonstrate that they were engaged in "good faith" negotiations with private interests willing to build any or all portions of the intertie system. It was not enough to lead the world in the creation and use of extra-highvoltage electrical systems; the United States needed to show the world that its superior electrical grids were made possible through the benefits of a free enterprise system.

In 1963 negotiations for the planning and construction of the Pacific Intertie became increasingly bound to the fates of the regional preference bill and the Columbia River Treaty. In order for the intertie to be built, Congress had to pass regional preference legislation. As it happened, the fate of the Columbia River Treaty became similarly reliant on the successful passage of the regional preference bill, particularly since it was a precondition for the creation of the Pacific Intertie and the transmission of Canadian (firm) power to the California market. Of course, if Canadian power was made available through the full ratification of the Columbia River Treaty, the federal yardstick for the Pacific Intertie would necessarily have to be modified to allow for at least three transmission legs between the Northwest and Southwest. In these negotiations, everyone stood to benefit. The BPA hoped to sell its secondary power south and use replacement (off-peak) power to firm up its electrical system. Interests south of Oregon stood to gain access to a considerable volume of energy that would not only firm up their electrical systems, but also help rationalize their own power production schemes. British Columbia, in turn, hoped to use the money from the sale of its treaty-related power entitlement to offset the cost of building three treaty-stipulated dams. 


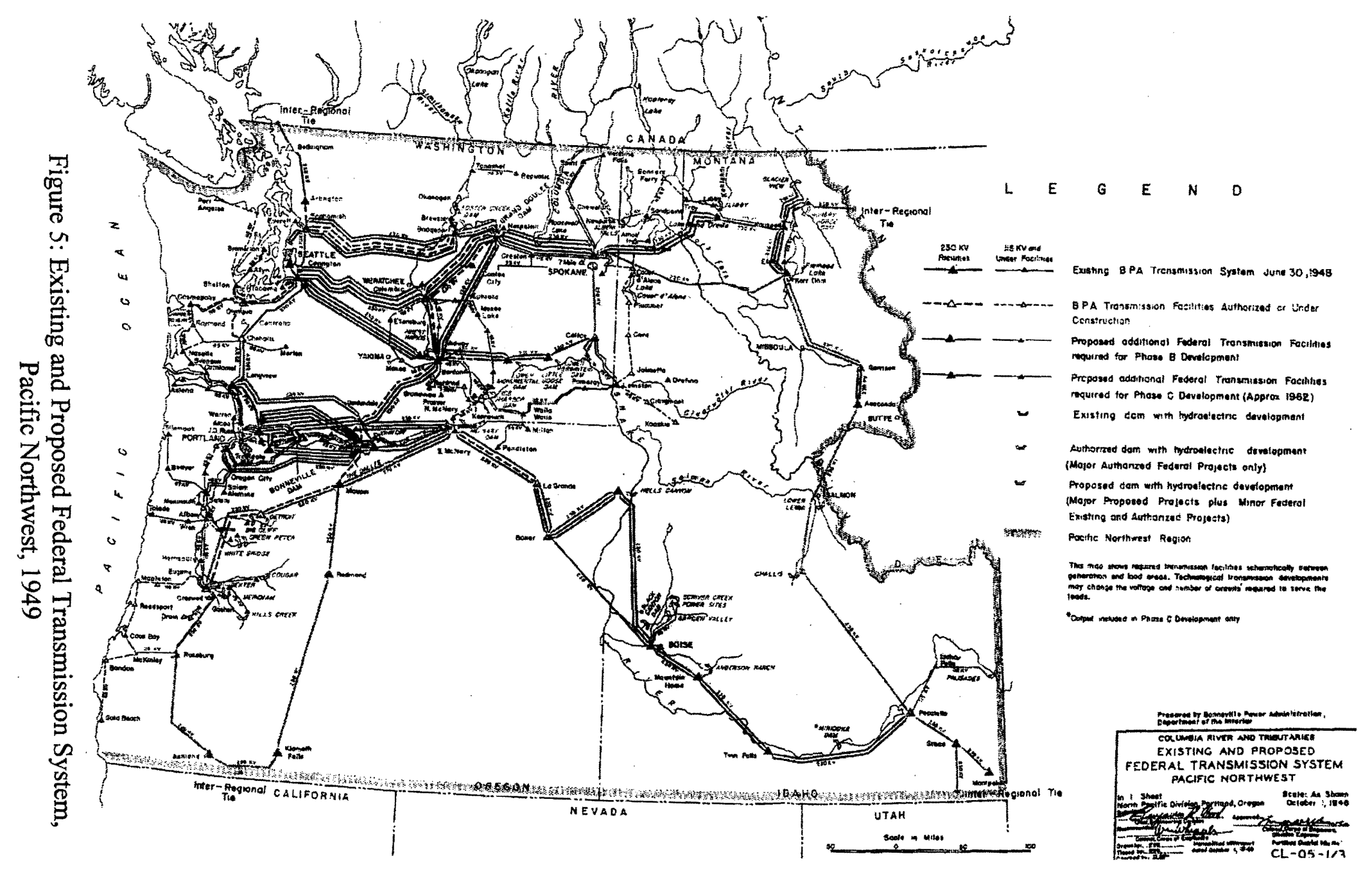


CHAPTER 4: Protecting Regional Interests

Even before the BPA had begun drafting regional preference legislation in spring 1961, efforts had been underway to safeguard the Pacific Northwest's federally produced hydropower supply. In the wake of the BPA's suspended (1958) plans to transmit surplus energy to PG\&E, the governors of Washington (Rosellini), Oregon (Hatfield), and California (Brown) signed a formal Statement of Agreement on July 9, 1959 , designed to initiate the study of "legal arrangements (federal statute or interstate compact) which can assure that [public] preference clauses cannot apply inadvertently or by design to power purchased from the Pacific Northwest to California." ${ }^{\text {"73 }}$ At the federal level, the governor's efforts to craft some form of regional protection for the Northwest took the form of S. 3880, which was introduced by Senator Hall Lusk (DOR) during the $86^{\text {th }}$ Congress at the request of Governor Hatfield. ${ }^{74}$ While Congress adjourned before any hearings could be held on S. 3880, a resolution on June 21, 1960, passed the Senate Committee on Interior and Insular Affairs requesting "the Secretary of the Interior to continue to suspend negotiations looking to the sale and transfer of surplus power or energy from the Pacific Northwest to California," effectively keeping the brakes on the transfer of any power between the regions. ${ }^{75}$

\footnotetext{
${ }^{73}$ Statement of Agreement Between the Governors of Washington, Oregon, and California on the Subject of the Proposed California Power Tie, July 9, 1959, PNW-PSW Intertie (July 1963 - Dec. 1963), Box 18119, RG 305, NARA Seattle.

${ }^{74}$ Charles Luce to Robert Thornton, Attorney General of Oregon, April 12, 1962, PNW-PSW Intertie (Apr. 1962-Dec. 1962), Box 18118, RG 305, NARA Seattle. Lusk introduced S. 3880 at the request of Oregon's Governor Mark Hatfield.

${ }^{75}$ Unsigned draft letter from Stewart Udall to Clinton P. Anderson, Chairman, Senate Committee on Interior and Insular Affairs, ca. mid-Dec. 1961, PNW-PSW Intertie (Sept. 1961 - Dec. 1961), Box 18118, RG 305, NARA Seattle.
} 
Almost a full year passed before the BPA began widely distributing drafts of a new regional preference bill for comment, but by June 1961 the BPA had heard from thirty-five interested parties in the Pacific West states. While the majority of respondents in the Northwest understandably looked on the regional preference bill rather favorably, Californian interests were more critical. As could be expected, private interests were cold to the idea, particularly since it was being promoted by the BPA as a necessary precursor of the construction of any federally owned interties across their marketing territories. Not surprisingly, the Golden State's public utilities, whose interests in the Northwest's energy supplies were being negated by any legislation that would nullify the BPA's charter to provide a preference to publicly owned agencies, also offered some critical comment.

The most common criticism leveled by California's public agencies was that the BPA's preference draft, as it was then written, placed restrictions on the sale of any power produced in the Pacific Northwest. The California Department of Water Resources, for example, found it "difficult to see the basis for including in the legislation provisions which would automatically establish corresponding limitations on thermal or non-Federally developed power." ${ }^{76}$ With many of California's public power agencies being dependent upon hydropower themselves-and some, like SMUD being wholly invested in hydropower production - a north-south intertie raised

\footnotetext{
${ }^{76}$ Reginald Price, Acting Director of California Department of Water Resources, to Charles Luce, July 21, 1961, PNW-PSW Intertie (July 1961 - Aug. 1961), Box 18118, RG 305, NARA Seattle. The following organizations and city agencies were in agreement on this point: California Department of Water and Power, Northern California Municipal Electric Association, L.A. Department of Water and Power, Sacramento Municipal Utility District, Roseville, Burbank, Pasadena, Riverside, Colton, Glendale, and the Anza Electric Co-op.
} 
the hopes that they would be able to gain access to firm power available from Northwest producers. However, Luce was similarly interested in firming up the BPA's system with the addition of thermal power plants, most importantly through the commercial generation of power at the U.S. government's Hanford Nuclear Reservation in Eastern Washington. Not surprisingly, Luce leaned toward the inclusion of federally produced nuclear power in the regional preference legislation. Another oft-repeated criticism was leveled at the BPA's insistence that the energy sent between regions be a reciprocal exchange. The BPA wanted an assurance that its supply of peak power would only be made available to those parties who were able to arrange for an equal return of off-peak energy. For power producers whose production portfolios included thermal-generation power plants, this reciprocal exchange worked well, especially because thermal plants operated with greater efficiency when allowed to run at a steady level of output. But for utilities without any thermal-power capabilities, like SMUD, participation in energy exchanges with the BPA would be impossible unless they either built their own thermal plants or negotiated some kind of arrangement with another party (for SMUD, this would by necessity be PG\&E) to reciprocate off-peak energy to the BPA. Additionally, managers at California's Department of Water Resources also felt that some of the BPA's peak power supply should be eliminated from mandatory reciprocation:

It is unrealistic to require the return of provisional energy except during the storage release period in which it was delivered...Under some conditions, energy furnished in association with peaking capacity should not be required to be returned...energy associated with peaking capacity that could not have been conserved should not be subject to return, and, as suggested for provisional energy, a limit should be 
placed on the elapsed time beyond which return of energy would not be mandatory. ${ }^{77}$

On December 22, 1961, the BPA sent a draft of the regional preference bill to the Department of the Interior, and on January 19 , it was submitted to Congress. ${ }^{78}$ At the same time that the draft was being readied for Congressional consideration, Oregon's Governor Hatfield and staff were working behind the scenes, through direct communication with Luce, to amend the bill without drawing attention to their efforts. According to Hatfield, "It has disturbed me...that there has never been a clean-cut attempt by the BPA or the DOI to straightforwardly tell the people of the Northwest that there is no possibility of permanent protection." Hatfield also pointed out "There is no provision that would prevent power from being offered for sale outside the Northwest at prices lower then those at which it could be offered within the Northwest." Furthermore, Hatfield believed the bill was flawed with unclear definitions and a lack of "definite standards to guide the Administrator."

Luce responded to Hatfield by reminding him that while there were some similarities to the problems that could have grown out of the BPA-PG\&E arrangement being considered in 1958, the situation had changed. Luce pointed out two important differences:

\footnotetext{
${ }^{77}$ William Warne, Director of Water Resources at California Department of Water Resources, to Bernard Goldhammer, Nov. 17, 1961,.PNW-PSW Intertie (Sept. 1961 - Dec. 1961), Box 18118, RG 305 , NARA Seattle.

${ }^{78}$ The draft submitted to Congress still applied to all federal projects in the Northwest, not just hydropower plants.

${ }_{79}$ Mark Hatfield to Charles Luce, Feb. 21, 1962, PNW-PSW Intertie (Jan. 1962 - Mar. 1962); Hatfield to Luce, Apr. 10, 1962, PNW-PSW Intertie (Apr. 1962 - Dec. 1962); both in Box 18118, RG 305, NARA Seattle. Apparently at Luce's request, Hatfield had "refrained from releasing [his staff's evaluation of the draft] report to the public, refrained from sending [Luce] a copy of the report and directed Mr. [Jonel] Hill [Oregon's Public Utility Director] to orally advise [Luce's] representatives of the specific objections. This was accomplished January 18, 1962."
} 
1) $P G \& E$ and $P P \& L$ are going to build such an interconnection regardless of Bonneville's approval; and

2) They are going to build a $500 \mathrm{kv}$ line, having four times the capacity the $230 \mathrm{kv}$ line proposed in 1960 [the year S. 3880 was introduced by Senator Lusk $]^{80}$

Addressing Hatfield's criticism regarding the BPA's failure to publicize the nonpermanency of the bill's safeguarding of the Northwest, Luce conceded:

We do not, of course, pretend that the bill we have drafted is permanent...But the current bill, because of its requirement for incorporating a regional preference into contracts, assures protection to the region for a longer period than did the 1960 bills. $^{81}$

Luce then pressed Hatfield to lend his political support to the uphill struggle for the bill, pointing out, "Unless we can present a united front in our own region and with California, the chances of enactment will be very slim indeed. ${ }^{82}$

In 1962 several regional preference bills were introduced in the Interior Committees of the House and Senate: 1) S. 3153 (by Clinton P. Anderson, D-NM); 2) H.R. 11265 (by Gracie Pfost, D-ID); and 3) H.R. 11264 (by Julia Butler Hansen, DWA). In the Senate, hearings were held on S. 3153 on May 21 and 22, leading to two amendments to the bill. The first, and most important, was the BPA's decision to backpedal on its insistence that the preference legislation apply to all federally produced power. Limiting the bill to federal hydropower projects appeared to the BPA as a way to smooth the path for the support of California's congressional delegation.

\footnotetext{
${ }^{80}$ Luce to Hatfield, Mar. 22, 1962, PNW-PSW Intertie (Jan. 1962-Mar. 1962), Box 18118, RG 305, NARA Seattle.

${ }^{81}$ Ibid.

${ }^{82} \mathrm{Ibid}$.
} 
Another amendment was added to the bill in order to blunt threatened opposition from Montana's congressional delegation. The exclusion of Eastern Montana in the bill's definition of the Pacific Northwest caused worries among many Montanans that the geographical preference already established for statewide priority access to power from the Hungry Horse Dam (located in northwestern Montana) would be negated. As that was not the intent of the bill, Luce saw no problem in seeing an amendment added to state, "nothing in this bill is to be construed as restricting or weakening the Hungry Horse reservation." 83

In August, following the ultimately unsuccessful efforts of senators Barry Goldwater (R-AZ) and Karl Mundt (R-SD), who pushed for amendments extending the principle of regional preference to other major river basins in the country, the Senate approved the bill by a vote of 51 to $36 .^{84}$ Once in the House, the bill never made it out of committee, and the $87^{\text {th }}$ Congress came to a close without any more progress. ${ }^{85}$ Soon after the $88^{\text {th }}$ Congress commenced in 1963, a new round of regional preference bills were introduced: 1) H.R. 994 (by Julia Butler Hansen, D-WA); 2) H.R. 1160 (by Alfred Westland, R-WA); H.R. 4071 (by Al Ullman, D-OR); H.R. 4485 (by Compton White, D-ID); and S. 1007 (by Henry "Scoop" Jackson (D-WA), Warren Magnuson (D-WA), Wayne Morse (D-OR), Maurine Neuberger (D-OR),

\footnotetext{
${ }^{83}$ S.R. Logan to Luce, April 24, 1962; Luce to Logan, April 27, 1962; both in PNW-PSW Intertie (Apr 1962 - Dec. 1962), Box 18118, RG 305, NARA Seattle; and Norwood, "Administrative Challenge and Response," 58.

${ }^{84}$ Norwood, "Administrative Challenge and Response," 58. Mundt went further than Goldwater, pushing for regional preference for "all federal energy," not just hydropower.

${ }^{85}$ Ibid., 59.
} 
Frank Church (D-ID), Leonard Jordan (R-ID), Lee Metcalf (D-MT), and Mike Mansfield (D-MT). ${ }^{86}$

Most important of all these bills was S. 1007, which was co-sponsored by all eight senators from Oregon, Washington, Idaho, and Montana. In April 1963 the Senate moved quickly to pass the legislation. After formally adopting the previously held Senate Interior Hearings of May 21, 1962 on S. 3153, the bill moved out of committee (on April 5) and was passed by the full Senate on April $23 .{ }^{87}$ Once in the House, the bill's momentum slowed. Northwestern governors pushed for the bill's passage. Albert Rosellini, Governor of Washington, for example, appeared before the House Committee on Interior and Insular Affairs on May 14 in support of S. 1007. He argued that the Bonneville Power Act of 1937, which limited the BPA's marketing area to those areas within "economic transmission distance" had become outdated with advances in technology. Rosellini pointed out to the committee that this definition "could encompass most of our country situated west of the Mississippi River." ${ }^{88}$ With the majority of opposition to S. 1007 coming from California's congressional delegation, Oregon's Governor Hatfield attempted to enlist the aid of California's Governor Brown to persuade the bill's detractors to drop their protests. In a June 19 letter, Hatfield suggested to Brown that his "support would undoubtedly do a great deal to accomplish the Intertie," but made sure to warn him that "without passage of

\footnotetext{
${ }^{86}$ Ibid., 73. Henry "Scoop" Jackson (D-WA) was chair of the Senate Interior and Insular Affairs Committee, and Michael Mansfield (D-MT) was Senate Majority Leader during the $88^{\text {th }}$ Congress. ${ }^{87}$ Ibid.

${ }^{88}$ Statement of Honorable Albert D. Rosellini, Governor of Washington, Before the House Committee on Interior and Insular Affairs, May 14, in Support of H.R. 1160, H.R. 4071, H.R. 4485 and S. 1007, PNW-PSW Intertie (Apr. 1963 - June 1963), Box 18119, RG 305, NARA Seattle.
} 
this regional preference legislation, the Northwest will of course be required to remain in opposition to any Intertie."

On June 26, the effort to pass S. 1007 ground to a halt with the addition of an amendment by one of Washington's Republican representatives, Alfred Westland, which read:

No electric transmission lines or facilities shall be constructed outside the Pacific Northwest by any Federal agency for the purpose of transmitting electric energy for sale or exchange pursuant to this Act except those lines and facilities hereafter specifically authorized by the Congress. $^{90}$

The amendment was popular to members of the House who suspected any federally owned intertie because they believed it smacked of socialism. However, for the BPA, though, whose negotiating position with California's private utilities relied largely upon their ability to move forward with a federal intertie system if they so desired, the amendment was a poison pill. Public utilities across the West immediately withdrew their support of the bill because of the Westland Amendment. Owen Hurd, Chairman of the Pacific Coast Coordinating Committee, which represented " 175 consumerowned electrical systems in Washington, Oregon, Idaho, Montana, Nevada, California, and Arizona," sent a telegram on July 8 to members of the House Committee on Interior and Insular Affairs, arguing for the amendment to be stricken from the bill:

Westland amendment would impede proper integration of existing federal systems for greatest return on taxpayers' dollar, drastically weakens government's negotiating position respecting possible non-federal Intertie proposals, jeopardizes chances for approval of the Canadian Treaty, and means higher costs for

\footnotetext{
${ }^{89}$ Mark Hatfield to Edmund Brown, June 19, 1963, PNW-PSW Intertie (Apr. 1963 - June 1963), Box 18119 , RG 305, NARA Seattle.

${ }^{90}$ Norwood, "Administrative Challenge and Response," 75.
} 
Northwest and Southwest consumers but lowers returns to the United States treasury.

Westland amendment strengthens Pacific Gas and Electric Company's monopoly position, creates 'transmission tollgates' and endangers and weakens legislation to establish ground rules for any Pacific Northwest-Southwest Intertie. ${ }^{91}$

On August 27, S. 1007 (with the Westland amendment) was brought to the floor for a two-hour debate and subsequently passed the House by a voice vote. By December the conference committee reported that it was unable to reach a compromise, and the two houses remained in stalemate until the summer of $1964 .^{92}$

As Douglas Norwood points out in "Administrative Challenge and Response," the primary issue leading to stalemate over the regional preference bill was not the principle of regional preference itself. The resistance in the House, rather, grew from ideological opposition to federal ownership of the Pacific Intertie. While the BPA was able to build a certain degree of consensus by conditionally linking the construction of the Pacific Intertie to the passage of a regional preference bill, the same linkage gave detractors an opportunity to force the BPA to continue negotiations with California's private utilities from a much less advantaged position than they otherwise would have had. Because S. 1007 stalled in 1963, the BPA was not able to appropriate funds to start construction of their intertie program in 1964 . Without those funds, the BPA's leverage over California's private utilities was reduced in the subsequent negotiations over the intertie system.

\footnotetext{
${ }^{91}$ Teletype from Owen Hurd, Chairman of Pacific Coast Coordinating Committee, to James Carr, Under Secretary of the Interior, July 9, 1963, PNW-PSW Intertie (July 1963-Dec. 1963), Box 18119, RG 305, NARA Seattle.

${ }^{92}$ Norwood, "Administrative Challenge and Response," $75-76$.
} 


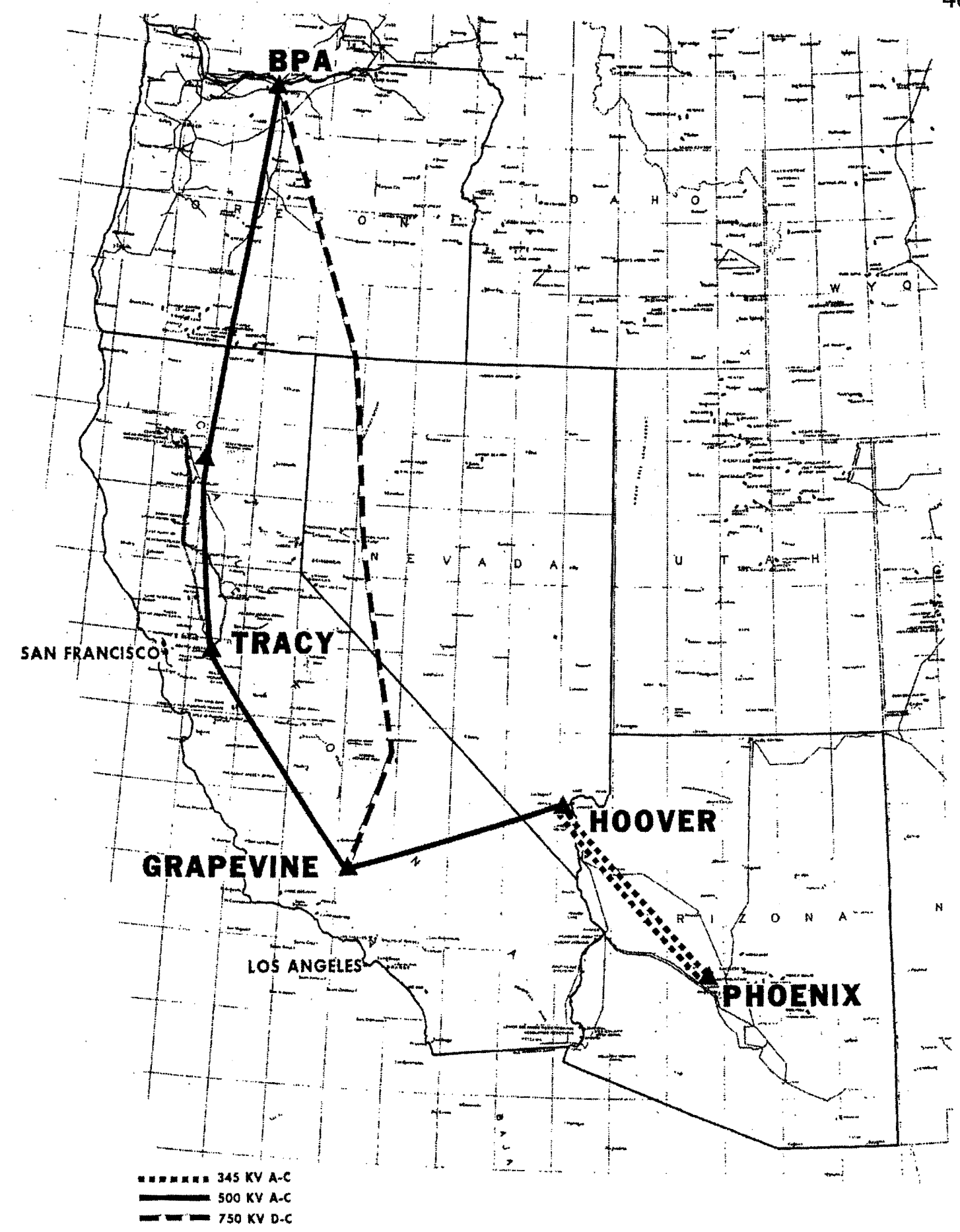

Pacific Northwest-Pacific Southwest Intertie Federal Yardstick, March 1964

Figure 6: Pacific Northwest-Pacific Southwest Intertie, Federal Yardstick, March 1964 


\section{CHAPTER 5: Congressional Appropriations}

Throughout all of the negotiations surrounding the creation of the Pacific Intertie, the ownership and control of the transmission lines remained the most contested questions. Advocates of public power fought for the construction of federal lines across California in order to break the virtual monopolies of the California Power Pool companies. Private utilities, likewise, fought against public ownership of the lines in order to maintain their monopolies and believed that power sold by publicly subsidized brokers, like the BPA, was artificially priced below market value and thus created unfair competition. Advocates for private construction agreed, but their protest of federal control extended beyond worries of profits or tax rolls. Many of the proponents of a non-federal intertie distrusted federal ownership of any of the country's infrastructure, particularly its electrical transmission systems, seeing such as a dangerous move toward socialism. In contrast, the public agencies located at each end of the intertie had much to gain from the construction of the Pacific Intertie. The BPA hoped to get its budget back in the black, firm up their system by selling surplus power to Southern California, and exchange peak power for off-peak power. The City of Los Angeles, in turn, needed an increasing amount of supplementary energy to power the pumps sending water hundreds of miles into the city, to satisfy its residents' needs for air conditioning, and to maximize the productivity of their own system through the exchange of peak and off-peak power with the north. 
As controversy over the shape of the Pacific Intertie continued into 1963, various public agencies in central and northern California, and their supporters, became increasingly critical of the plans that did not include a federally owned line running south to Tracy, California. As they saw it, the benefits of the intertie were increasingly likely to be limited to the BPA, the California Power Pool, and the City of Los Angeles. Subsequently, their continued support for the project became linked to finding a way for the Pacific Intertie to more sufficiently meet the needs of the Bureau of Reclamation's Central Valley Project, the California Water Project, and SMUD. In 1963, while Congress was considering the regional preference bill (S. 1007), much of debate over the fate of the Pacific Intertie revolved around the Congressional appropriation of funds to begin construction of any federal lines. It was these latter negotiations that would establish the conditions for the final round of meetings, to be held in 1964, regarding the shape of the Pacific Intertie. If Congress were to authorize funding to begin construction of a federally owned intertie, the California Power Pool's negotiating leverage dissolved. If, however, Congress denied federal planners funds to begin construction, their own leverage considerably diminished.

At the start of 1963 , the momentum seemed to favor the public agencies. A study group composed of representatives from California's private utilities, the BPA, California Water and Power, and Bureau of Reclamation met in Los Angeles to examine the costs associated with power sales and electrical transmission between the 
Northwest and Southwest. The most important outcome of this meeting was the increased validity of the federal yardstick. According to Goldhammer:

The general feeling was that the Task Force Report on costs was high. Transmission facilities could be built more economically than indicated in the Task Force Report. I pointed out that the Task Force took the higher estimates on the basis that if the lines were feasible under these estimates, they would be feasible if the costs were less. ${ }^{93}$

If the study group had determined the task force had underestimated the costs associated with the construction and operation of the Intertie, the private utilities would have new political ammunition to use during appropriation hearings and in their public relations efforts. As it was, the overly conservative estimates provided even more justification for the construction of the Pacific Intertie-and more incentive for the various parties to bring the vision of the intertie to reality.

Luce and Udall quickly followed up the January 2 study group meeting with another, with officials from PG\&E in San Francisco. At that meeting, PG\&E was told, in no uncertain terms, that their proposal to be the marketing agent for all power sent south of the Oregon border was unacceptable to the BPA and the Department of the Interior. From PG\&E's perspective, regional protection legislation was unnecessary if power sold to public agencies in the Southwest could be marketed by a private utility, at federal rates, rather than by the BPA. According to Luce, he and Udall informed PG\&E:

Their proposal to purchase power from BPA and resell it to the public agencies would not be acceptable. The Secretary's position is that if PG\&E constructs the Intertie, BPA should sell directly to the ultimate

\footnotetext{
${ }^{93}$ Bernard Goldhammer to Charles Luce, Conference Report regarding Jan. 2, 1963 Meeting of the Study Group on the PNW intertie with California utilities, held in Los Angeles, Jan. 10, 1963, PNWPSW Intertie (Jan. 1963 - Mar. 1963), Box 18119, RG 305, NARA Seattle.
} 
purchaser and PG\&E should wheel the power from the Oregon-California border to the purchaser. ${ }^{94}$

Bonneville had no desire to enable PG\&E to become the sole marketer of federal power to customers south of the Oregon stateline. Not only would such a move be legally precarious, since courts might still consider the public preference clause of the BPA's charter in effect, but the positioning of the country's largest private electrical utility as the Pacific Intertie's "toll gate operator" and only purchaser of power available to the BPA was not viable.

President Kennedy's January 17 budget message called on Congress to appropriate funds to begin construction of the Pacific Intertie and raised the stakes for PG\&E and the other members of the California Power Pool. Kennedy called for:

Funds to start construction of major extra-high voltage interconnections linking the electric systems of the Pacific Northwest and Pacific Southwest. The interconnections will provide for sale and exchange of power between California and the Northwest, resulting in substantial economies to both regions. Prompt action is expected on legislation proposed last year to reserve necessary power supplies for the Pacific Northwest. ${ }^{95}$

If Congress were to appropriate funds for the start of intertie construction, the Power Pool would be forced to acquiesce much of their vision for the intertie to the BPA, which had already demonstrated a strong desire to build at least one, and maybe two, federal lines into the Southwest.

Even while the negotiating strength of the BPA appeared to be gaining a head of steam in January, the concerns about the fate of public power purchasers in central

\footnotetext{
${ }^{94}$ Minutes of Administrator's Staff Meetings, Volume 4: 1963 - 1964, Jan. 9, 1963, BPA Library.

${ }_{95}$ A. Lars Nelson, Master of Washington State Grange, to Charles Luce, Jan. 31, 1963, PNW-PSW Intertie (Jan. 1963 - Mar. 1963), Box 18119, RG 305, NARA Seattle.
} 
and northern California continued to surface. According to Gus Norwood,

Executive Secretary of the Northwest Public Power Association, for example, even the

President's budget message was problematic:

It would appear that the Budget Message does not contemplate the inclusion of three important power purchasers or exchangers in California: 1) the State itself in connection with the California Water Plan, 2) Sacramento Municipal Utility District, and 3) the Central Valley Project and its state, federal, public and cooperative customers.

The obvious remedy to this possible omission would be the provision for construction of a Bureau of Reclamation 500,000 volt A.C. line from Tracy to interconnect with the BPA 500,000 volt line near Klamath Falls. ${ }^{96}$

The public agencies in California hoped to bypass the monopoly control of PG\&E in the transmission of energy from the Northwest by advocating for the building of a federally owned portion of the intertie between Tracy, California, and Klamath Falls, Oregon. The California Power Pool's January proposal to build two 500-kv ac interties stretching from Oregon to Los Angels complicated that effort. Not only was their proposal the most advanced of any submitted to the BPA, it was also well received. Although they wanted better terms before moving forward, the BPA was very interested in the Power Pool taking an active role in the construction and operation of at least part of the intertie system. To Goldhammer, it was "highly desirable to obtain the full participation of the California Power Pool because these utilities serve approximately three-fourths of the load in California."97

The Power Pool's proposal to build two AC legs of the intertie also had the effect of modifying the plans of the BPA's Task Force for the overall system. If the

\footnotetext{
${ }^{96}$ Gus Norwood to Charles Luce, Jan. 30, 1963, PNW-PSW Intertie (Jan. 1963 - Mar. 1963), Box 18119 , RG 305, NARA Seattle.

${ }^{97}$ Minutes of Administrator's Staff Meetings, Volume 4: 1963 - 1964, Feb. 6, 1963, BPA Library.
} 
Power Pool were to build the two AC legs of the intertie, as they proposed, the federal government would be able to save an estimated $\$ 26,892,000$ by routing a third DC leg of the intertie through Nevada to Los Angeles, rather than through northern and central California. This alternative gained traction with federal planners by midFebruary and led the BPA and Department of Interior to encourage public agencies and utilities in California to begin arranging for wheeling contracts with the private utilities that would allow them to exchange power with the BPA over Power Pool lines. $^{98}$

Of course, neither the BPA nor the Power Pool had yet to concede defeat in disputes over how energy would be transmitted to California. At a February 19 meeting with Howard Allen, President of Southern California Edison, and Robert Gerdes, Executive Vice President of PG\&E, Luce and Goldhammer reiterated the BPA's insistence that the BPA deal directly with any and all customers south of Oregon. Gerdes, in turn, argued that the sale of all power to PG\&E and the crafting of subsequent company contracts to sell the power to third parties "would provide an insulation against the preference clause operating to the disadvantage of Northwest." Gerdes then pointed out that "the Chief Counsel for Los Angeles was satisfied that his arrangement was better than the legislation we [BPA] proposed." Luce, in turn, replied that he did not believe the contracts would "prevent the preference clause from

\footnotetext{
${ }^{98}$ Memo from E. J. Harrington, Chief of System Engineering, Bureau of Reclamation, to Eugene White, Chief Engineer, regarding Interchange Capacity of $375 \mathrm{kv}$ - Pacific Northwest-Pacific Southwest Tie, Feb. 18, 1963, PNW-PSW Intertie (Jan. 1963 - Mar. 1963), Box 18119, RG 305 NARA Seattle. The construction of a federal line from Oregon, through Nevada, into Southern California was attractive because the shorter route was less expensive in regard to both construction and right-of-way. Wheeling contracts allow for an owner of a transmission line to provide for power to be exchanged between two separate parties, while compensating the owner of the line for the service.
} 
operating, and that the courts would look to the substance and not the form of his proposed contracts, the substance being the cities of Los Angeles, Sacramento, etc. [sic] would be customers of Bonneville." ${ }^{.99}$

According to Luce's assessment of the Feb. 19 meeting with Gerdes and Allen, the Power Pool's opposition to the regional preference legislation was "based entirely on their fear that with the Bill [establishing regional preference] the political path would be cleared for an all federal line or lines." ${ }^{.100}$ Luce's commitment to working with the companies, even while simultaneously seeking to strengthen his agency's negotiating leverage through Congressional approval of the regional preference bill and the earmarking of appropriations to begin construction of a federal line, was made clear in the same memo, where he concluded:

I'm convinced that if we can settle the transmission line issues in some way whereby the companies build the big lines in California, that they will concede to the points that the contracts should be directly between Bonneville and each of its California customers and will withdraw opposition to the legislation. However, no representative of the company has actually come out and said that such is the case."101

By March, the BPA was moving forward with the assumption that the California Power Pool would most likely build and operate the two 500-kv AC legs outlined in their formal proposal. But, still wanting to see a DC line built, and now looking to run it south through Nevada, the BPA began looking for ways to increase the economic feasibility of the DC line. Their best option to make that line a reality

\footnotetext{
${ }^{99}$ Memo from Charles Luce to Assistant Secretary of Water and Power, regarding Feb. 19, 1963 Meeting with representatives of Pacific Gas \& Electric and Southern California Edison, Feb. 22, 1963, PNW-PSW Intertie, Jan 1963 - Mar. 1963, Box 18119, RG 305, NARA Seattle.

${ }_{100}$ lbid.

${ }^{101}$ Ibid.
} 
involved linking the federal hydrosystems of the Columbia and Colorado River systems. Accomplishing this required integrating Hoover Dam directly into the Pacific Intertie system, so the BPA began considering two options: 1) establish Hoover Dam as the southern terminus of the DC line; or, 2) build a short intertie between Hoover Dam and the southern terminal of a DC line stretching from The Dalles Dam to Los Angeles. Either way, according to BPA, "The city of Los Angeles would need about one-half the capacity of the line, and this would assure its financial feasibility." 102

The BPA began pushing for the integration of Hoover Dam into the Pacific Intertie system, even though they were well aware of the opposition such a move would receive from the California Power Pool. In particular, PG\&E worried that the interconnection of the two river systems "would unload lines that the California Power Pool had built to take care of BPA loads in California." Additionally, Southern California Edison feared the line "would introduce power directly into the systems of a number of Southern California Edison's customers."103 Federal planners, however, were most interested in maximizing the potential efficiency of future energy exchanges between the regions. From the Department of Interior's perspective, there was a clear and immediate advantage in connecting the hydroelectrical systems of the Columbia and Colorado. Not only could the BPA supplement the Bureau's power supply during the period of time required to fill the Glen Canyon Dam's reservoir, then being estimated to last between eight and thirty years, but the BPA could also

\footnotetext{
${ }^{102}$ Minutes of Administrator's Staff Meetings, Volume 4: 1963 - 1964, Mar. 25, 1963, BPA Library. ${ }^{103}$ Memo from Luce to Assistant Secretary of Water and Power, Feb. 22, 1963, PNW-PSW Intertie, Jan 1963 - Mar. 1963, Box 18119, RG 305, NARA Seattle.
} 
provide assistance during water-short years in the future. ${ }^{104}$ For the BPA, such a connection assured yet another customer for their surplus power. And, for the Bureau, the additional energy made available through the Pacific Intertie would allow them to fill Glen Canyon much faster than originally planned while also providing more stability to their system. ${ }^{105}$

The BPA's steady consideration of a federal DC line continued to provide their intertie planners with a considerable bargaining chip in ongoing negotiations. If the Department of Interior was able to gain Congressional authority to build a federally owned line, connecting the BPA's grid in the Northwest with the Bureau of Reclamation's and the City of Los Angeles' grids in the Southwest, the Power Pool would either have to defeat the subsequent efforts to appropriate construction funds, or they would have to outmaneuver the federal planners by drawing away potential customers in Arizona. The latter option would, in turn, require substantial investments by a private utility, most likely Southern California Edison, into both the integration of the Southwest's sub-regional electrical grids and the addition of substantial amounts of energy to the area's customers.

Congressional appropriation hearings began in June to consider the Department of Interior's request for funds to begin construction of the Pacific Intertie. The BPA's budget called for $\$ 23$ million $-\$ 1.5$ million for preliminary engineering, the rest to begin construction of both the $500-\mathrm{kv}$ AC line between the Columbia River

\footnotetext{
${ }^{104}$ Earl Ostrander, Director of Administrative Management, BPA, to Charles Luce, Aug. 2, 1963, PNW-PSW Intertie (July 1963 - Dec. 1963), Box 18119, RG 503, NARA Seattle.

${ }^{105}$ The interconnection of the two federal hydrosystems would have also widened the Bureau's options in supplying power to customers in both the Colorado River region and the Lower Missouri region through the displacement of power.
} 
and PGE's Round Butte Complex and a 750-kv DC line between The Dalles Dam and the Oregon-Nevada border. The Bureau of Reclamation, in turn, asked Congress for $\$ 4$ million to begin construction of the southern end of the DC line. ${ }^{106}$ Udall justified the appropriation by drawing attention to the millions of dollars wasted every year on the Columbia system because of the lack of extra-high voltage transmission lines reaching south into California and the Southwest. He also stressed the importance of constructing a DC line for the "reasons of technological advancement, of economy, and of our Nation's stature in the electrical field."107 Importantly, both Udall and Luce acknowledged that, while they were asking Congress to write a check to begin construction of the Pacific Intertie, negotiations over its final shape and ownership were still in process and the agencies' plans could still change. According to Udall,

The reason we request an appropriation is that we are in the process of negotiation. Some of these people will say to us, "We will build the line and we will provide transmission on very favorable terms." But whether we ultimately get terms that are favorable enough will depend upon whether we have the alternative to construct a federal line. If we don't have that alternative, we feel that we are not going to get favorable terms. ${ }^{108}$

As expected, representatives from the California Power Pool testified against the federal appropriations by reiterating the same arguments they had voiced since the beginning. They considered the construction of any federal lines south of Oregon

\footnotetext{
${ }^{106}$ Norwood, "Administrative Challenge and Response," 65 - 66.

${ }^{107} \mathrm{Ibid} ., 67$. The BPA estimated that it had lost the ability to market $\$ 33$ million worth of power during the previous year.

${ }^{108}$ Ibid.
} 
unnecessary. J.K. Horton, president of Southern California Edison, testified on

behalf of his company and typified the Power Pool's response:

We oppose expenditure of federal taxpayers' money for any Federal Government line, direct current or alternating current, within the State of California because investor-owned companies are ready, willing and able to provide adequate transmission service in California at no cost to federal taxpayers. ${ }^{109}$

In regard to the proposed DC leg, Horton also pointed out that his company had recently solidified plans to construct a 500-kv AC line between Southern California and Arizona.

The existence of this Arizona-California extra-high-voltage interconnection further eliminates need or even desirability for a federal direct current line through Nevada to Southern California, which relies upon a power market in Arizona and Nevada for its justification...We believe these power markets listed are not firm, realistic or reliable market projections and should not be used to justify the direct current line....The investor-owned companies in California do not intend to purchase any power over this single federal direct current line nor do they intend to provide stand-by reserve to support this federal direct current line to compete unfairly and sell power at unrealistic, federaltaxpayer-subsidized rates. ${ }^{110}$

PG\&E's Gerdes similarly rejected the need for any federal intertie and echoed Horton's claim that the Power Pool was not willing to interconnect their systems with the proposed DC leg because of its technological inadequacies and a basic incompatibility with standard $\mathrm{AC}$ transmission systems. The companies were afraid of exposing their systems to potential blackouts stemming from outages on the DC line. To compensate for the removal of the DC line from the plans for the Pacific

\footnotetext{
${ }^{109}$ Statement Before the Senate Appropriations Sub-Committee on Interior Power Marketing Agencies on Proposed Pacific Northwest-California Power Intertie, June 12 1963, by J. K. Horton, President of Southern California Edison Company, PNW-PSW Intertie, (Apr. 1963 - June 1963), Box 18119, RG 305, NARA Seattle.

${ }^{110}$ Ibid.
} 
Intertie, he pointed out that the companies had recently increased the planned capacity of their two AC lines (from a combined 1,500 mw to 2,000 mw). ${ }^{111}$ Gerdes also made clear his belief that, if Congress were to approve the appropriation requests and pass the regional preference bill, Luce would "put a loaded gun at the utilities' heads so that he can dictate, not negotiate, terms that are acceptable to him."112 The shrewd negotiating tactics of the federal planners, combined with the fluidity of their intertie plans, earned a raised brow from Senator Carl Hayden (D-AZ). Chairman of both the Senate Appropriations Committee and Public Works Subcommittee, he called upon Udall to clarify his testimony made during the summer hearings. In particular, Hayden wanted Udall to provide him with more background on what he meant in the hearings when he asked the committee to,

Consider what happened only last weekend. This California Power Pool-and they are tough, able negotiators-came up with an additional term that was highly favorable to us. This makes their offer much more attractive. We believe there is still some further ground to be gained. We are not completely satisfied with the offers as they stand at the present time, and it is our past experience in that we cannot get down to cases until we have the appropriations from Congress so that we can say, "Congress has given us some money. We are going to go ahead unless you offer us terms that are acceptable."113

Udall responded:

${ }^{111}$ During the 1963 appropriation struggle, the benefits and pitfalls of the commercial use of high voltage DC transmission were highly contested. Proponents relied heavily on testimony and subsequent written comments by Dr. Uno Lamm, Director of the Swedish ASEA, and inventor of many technologies that allowed for the application of extra-high voltage DC transmission to commercial operations. The California Power Pool relied on testimony from EBASCO, an engineering firm based in New York, which warned against prematurely integrating the technology into American AC electrical systems.

${ }_{112}$ Norwood, "Administrative Challenge and Response," 69.

${ }^{113}$ Carl Hayden to Stewart Udall, Aug. 21, 1963, PNW-PSW Intertie (July 1963 - Dec. 1963), Box 18119, RG 305, NARA Seattle. 
The point I was trying to make was that if we were unable to work out an agreement with the power companies, we would proceed with the D.C. line, which would result in a feasible operating system without reliance on arrangements with the power companies. Under such a circumstance we would not construct the section of the $500-\mathrm{kv}$ A.C. line north of California...it is our intention to construct the D.C. line unless a satisfactory alternate proposal is received. ${ }^{114}$

By the summer of 1963 , the strategy of the federal planners to gain leverage in the ongoing intertie negotiations came as no surprise to members of the Power Pool. Similarly, much of the testimony by members of the California Power Pool was already familiar to federal planners, and the formal submission of their arguments did little to change the momentum of negotiations. What did seem to come as a surprise was a June 24 announcement by Samuel B. Nelson, General Manager and Chief Engineer for Los Angeles Water and Power, that Los Angeles favored the proposal of the California Power Pool to supply the city with power over their two AC lines, in lieu of a federal DC line routed through Nevada. ${ }^{115}$

Once Los Angeles indicated a preference for an arrangement with the Power Pool, the economic feasibility of the Nevada routing of a federal DC intertie was put into enough doubt that federal planners changed their routing plans once again.

Subsequently, the Intertie Task Force renewed its original plans to build a federal DC line that stretched southward through California, with a tap at Tracy to supply the Bureau's Central Valley Project, the California Water Plan, and SMUD's power

\footnotetext{
${ }^{114}$ Udall to Hayden, Sept. 4, 1963, PNW-PSW Intertie (July 1963 - Dec. 1963), Box 18119, RG 305, NARA Seattle.

${ }^{115}$ Samuel Nelson to Carl Hayden, Oct. 8, 1963, PNW-PSW Intertie (July 1963 - Dec. 1963), Box 18119, RG 305, NARA Seattle.
} 
needs, before terminating at Sylmar, near Los Angeles. ${ }^{116}$ In an October 25 letter of support for the revised federal line, R. J. McMullin, General Manager of Arizona's Salt River Project, explained to Senator Hayden:

The load growth of public agencies in the Colorado River Basin and in the Northern California area is sufficient to provide a market for all foreseeable sources of hydro-electric power and energy. It is to be noted that the loads do not take into account the requirements of the City of Los Angeles, the municipalities in the vicinity of the City of Los Angeles, or the Metropolitan Water District. ${ }^{17}$

By the end of October, Secretary Udall, while acknowledging that he would continue to rely on help from "the Bureau and Bonneville people," asserted his authority over the ongoing Congressional negotiations by recommending to Assistant Secretary Holum, that "at this stage all policy matters should be determined by the Secretary." "18 Additionally, Udall reiterated his conviction that the intertie planners working under him not wed the Department of Interior to any specific routes for the Pacific Intertie while negotiations were still underway. Beyond that, he suggested that they "should make it clear that the major purpose of construction of the lines is to interconnect the Federal power systems from the Pacific Southwest to the Columbia River."119

\footnotetext{
${ }^{116}$ Draft letter from Stewart Udall to House Appropriations Committee, Oct. 17, 1963, PNW-PSW Intertie (July 1963 - Dec. 1963), Box 18119, RG 305, NARA Seattle. According to Udall, "If acceptable transfer arrangement could not be made over Los Angeles facilities, we would give consideration to recommending a federal line from Tracy to Hoover Dam to accomplish the interconnection."

${ }^{117}$ R. J. McMullin to Carl Hayden, Oct. 25, 1963, PNW-PSW Intertie (July 1963 - Dec. 1963), Box 18119 , RG 305, NARA Seattle.

${ }^{118}$ Stewart Udall to Kenneth Holum, Oct. 28, 1963, PNW-PSW Intertie (July 1963 - Dec. 1963), Box 18119, RG 305, NARA Seattle.

${ }^{119} \mathrm{Ibid}$.
} 
On November 5, in order to bring Hayden and the Senate Appropriations

Committee up to date, both Udall and Luce provided testimony describing the four leading options then under consideration by the federal intertie planners. ${ }^{120}$ Importantly, all four of the options presented to Congress were limited to two lines each, a result of the fact that Canadian power (from the yet-to-be ratified Columbia River Treaty) was still unavailable for formal consideration by intertie planners.

These four options included:

1. Two 500-kv ac lines stretching from the Columbia River to Los Angeles, with the Oregon portion built by the BPA and the California portion built by the Power Pool;

2. One 500-kv ac line running from the Columbia to Los Angeles, built by the BPA and the Power Pool, plus a 1000-kv dc line built by International Utilities stretching from the Columbia to Los Angeles via Nevada;

3. One 500-kv ac line running from the Columbia to Los Angeles, built by the BPA and the Power Pool, plus a 1000-kv dc line built by the BPA and International Utilities stretching from the Columbia to Los Angeles via Nevada; and

4. One 500-kv ac line running from the Columbia to Los Angeles, built by the $\mathrm{BPA}$ and the Power Pool, plus a federal 800-kv dc line running from the Columbia through Tracy to Los Angeles. ${ }^{121}$

Over the next month, both the House and Senate Appropriations Committees approved their versions of the 1964 Public Works Appropriations Bill. By then, half of the fiscal year had already passed, so the funds allotted to both the BPA and the Bureau of Reclamation were each below the levels originally requested. Specifically, Congress had allotted $\$ 6.5$ million for the BPA ( $\$ 1.5$ million for planning and development; $\$ 5$ million to begin acquiring land and equipment), and $\$ 2$ million for

\footnotetext{
${ }^{120}$ Norwood, "Administrative Challenge and Response," 71.

${ }^{121}$ Ibid.
} 
the Bureau (to begin acquiring land and equipment) in their efforts to begin building the Pacific Intertie. ${ }^{122}$

The House passed its version first, on November 15, with a condition that construction could not proceed until a regional preference bill was passed by Congress. The bill also specified that "at least one [of the two lines] shall connect with the California Power Pool System at the northern California border and be terminated at that point." Furthermore, the House Appropriations Committee stipulated:

Construction shall not begin unless the Secretary of the Interior finds, after good faith negotiations with utilities and other entities interested in constructing any portion of the lines involved, that their proposals will not result in benefits to the national interest at least equal to those to be derived from Federal construction, including revenues which will accrue to the Federal Government after amortization of the line or lines; has submitted his findings to the committee; and the committee has hand an opportunity to review them. ${ }^{123}$

For Udall, the appropriation levels were adequate, since roughly $\$ 20$ million of the BPA's requested $\$ 21.5$ million was intended for the advance purchase of DC equipment and half of the fiscal year had passed already. However, the House's requirement that at least one of the federally constructed lines connect the Power Pool's lines to the BPA's system at the Oregon-California state line seemed illconceived. In a November 29 letter to Senator Hayden, who was then in the process of working on the Senate's version of the bill, Udall warned:

\footnotetext{
${ }^{122} \mathrm{Ibid}$, 72. Note: Norwood's discussion of the budget allotment fails to mention the $\$ 1.5$ million for planning and development to the BPA, as his focus is on the funding of "construction" efforts. For a very thorough description of the appropriation amounts and conditions, see Stewart Udall to Charles Buckley, Chairman of the House Committee on Public Works, Apr. 24, 1964, PNW-PSW Intertie (Jan. 1964 - Apr. 1964), Box 18119, NARA Seattle.

${ }_{123} 1964$ Public Works Appropriation Bill, $88^{\text {th }}$ Cong., $1^{\text {st }}$ sess., 1963, H. Rep. 902, 54.
} 
The stipulation...imposes a restriction that is not necessarily in the best interests of the Federal Government. Based upon negotiations that have proceeded so far, there is no final assurance that a satisfactory arrangement can be made with the California Power Pool System, in which case no construction of the second line would be undertaken....The ability of the Department to effectuate such an overall relationship would be enhanced by the elimination of the abovequoted stipulation. ${ }^{124}$

Since the federal intertie planners were already fully engaged in negotiations with all of the parties that had shown interest in building portions of the intertie, the requirement for "good-faith negotiations" did not prove to be onerous. Rather, it likely helped infuse the process with a renewed sense of fairness, even while each of the parties continued their efforts to leverage negotiations in their favor. As a matter of fact, while the negotiations continued to play out, both Luce and Udall would increasingly reference this order when facing criticisms that the intertie plans were moving forward to the disadvantage of public agencies-or conversely, to the advantage of the Power Pool companies.

On December 5, the Senate Appropriations Committee passed its version of the 1964 Public Works Appropriations Bill, authorizing the appropriation of $\$ 8.5$ million to begin work on the Pacific Intertie. Importantly, the Senate Appropriations Committee agreed with Udall's assessment and struck the requirement to interconnect the BPA's grid to the Power Pool's (while still allowing for it). In fact, the Senate actually provided the federal planners with a considerable improvement in the legislation's language. Specifically, they added one sentence of significance.

\footnotetext{
${ }^{124}$ Udall to Hayden, Nov. 29, 1963, PNW-PSW Intertie (July 1963-Dec. 1963), Box 18119, RG 305, NARA Seattle.
} 
If it is determined that only one line shall be constructed at this time it shall be a direct current line to accomplish the interconnection of the Bonneville system, the Central Valley of California, and the Hoover Dam powerplant, the sale and exchange of Bonneville surplus power and energy and the sale and exchange of surplus power and energy between these areas. ${ }^{125}$

Congressional passage of the 1964 Public Works Appropriations Bill on December 31,1963, provided federal planners with a much-advantaged position for the final round of negotiations over the shape of the Pacific Intertie. Congress had given the federal planners an order to carry out those negotiations in "good faith" with the other parties involved, but if the federal planners could prove to Congress that they were not offered proposals "at least equal to those derived from Federal construction," they were well positioned to move forward with their own plans, without any formal requirement to link the Power Pool's grid to their own. With Luce and Udall already focusing the rhetoric of the federal effort around the concept of linking together the three federal power systems of the Columbia River, Central Valley Project, and Colorado River, the possibility certainly existed for the exclusion, or at least severely diminished role, of the Power Pool companies in the exchange of electrical power between the Northwest and Southwest. Subsequently, Congress had established a very strong incentive for the California Power Pool to accede to many of the terms forwarded by the federal negotiating team.

${ }^{125} 1964$ Public Works Appropriation Bill, $88^{\text {th }}$ Cong., $1^{\text {st }}$ sess., 1963, S. Rep. $746,40$. 


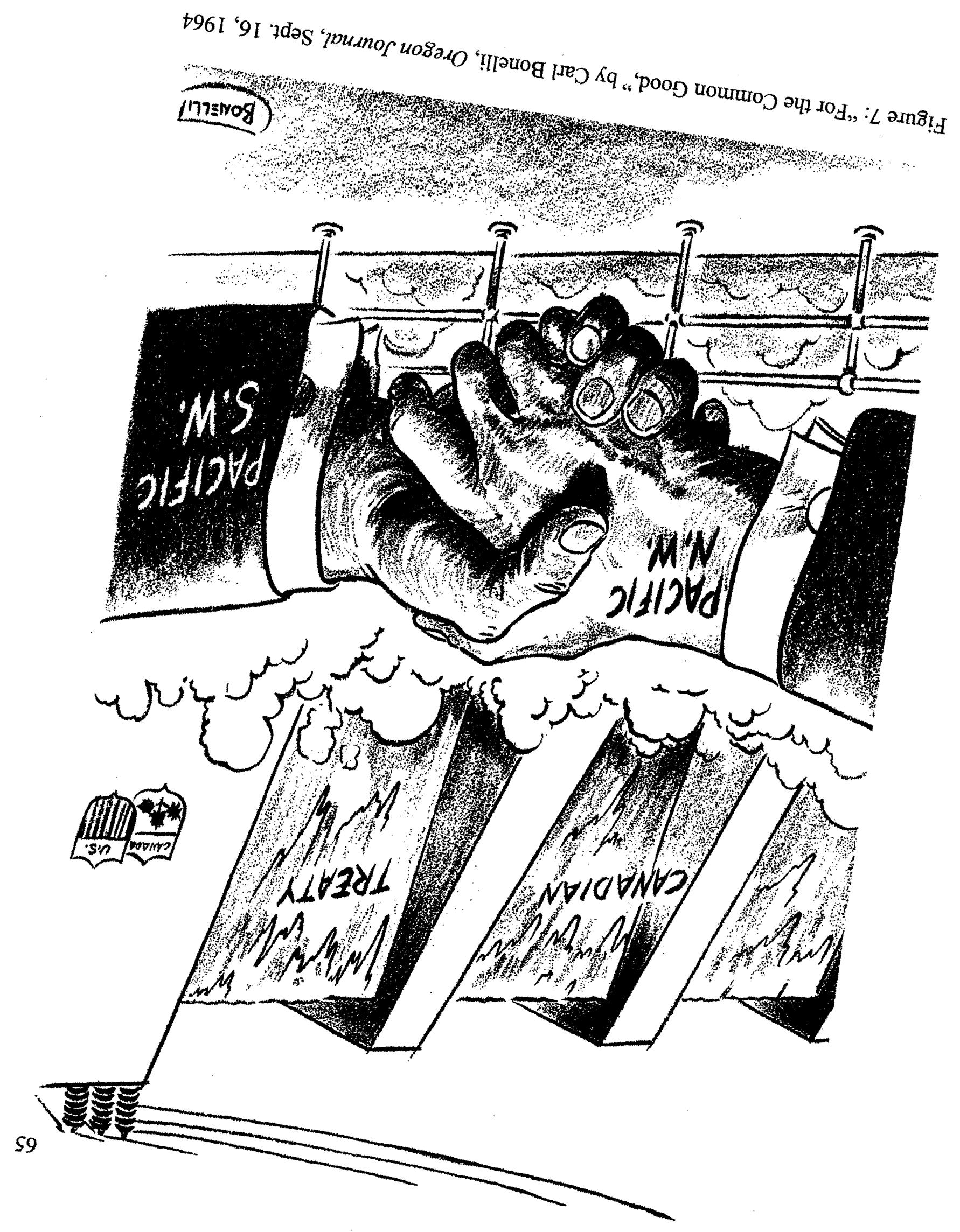




\section{CHAPTER 6: The Columbia River Treaty and the Canadian Entitlement}

On January 17, 1961, U.S. President Dwight D. Eisenhower and Canadian Prime Minister John Diefenbaker signed the Columbia River Treaty, marking the culmination of more than fifteen years of international study and negotiation over the cooperative development of the Columbia River system. Two months later, the U.S. Congress ratified the treaty; however, conflicts between British Columbia and Canada would delay Canadian ratification until $1964 .{ }^{126}$ In the interim between the American and Canadian ratifications of the treaty, the BPA's efforts to build the Pacific Intertie became interwoven with the fate of the treaty.

Efforts to craft a formal plan for the coordinated international management of the Columbia River system date back to 1944, when the United States-Canada International Joint Commission began the task of formally studying the feasibility of collaboratively developing the upper Columbia River Basin. ${ }^{127}$ While the American portion of the Columbia River Basin was already being extensively developed with hydropower projects by the early 1960 s, the majority of the existing and planned dams on the Columbia's mainstem were designed without much, if any, storage capacity. For example, federally built run-of-the-river dams like Bonneville, The Dalles, and McNary on the mid-Columbia, and mainstem dams built by public utilities in Washington (Priest Rapids, Wanapum, Rocky Reach, Rock Island, and Wells) were designed without any storage capability. In fact, the aggregate storage offered by all

\footnotetext{
${ }^{126}$ Springer, Power and the Pacific Northwest, $66-67$.

${ }^{127}$ Ibid., 65 . The U.S.-Canada International Joint Commission was established by the ratification of the Boundary Waters Treaty of 1909.
} 
of the Columbia Basin's mainstem and tributary dams (that fed into the Columbia upriver of the hydropower projects) amounted to approximately 21 million acre-feet, and Grand Coulee Dam accounted for almost a quarter of that volume. ${ }^{128}$ The Columbia River Treaty provided Americans with an opportunity to nearly double the storage capacity of the river's collective hydropower system by impounding an additional 20 million acre-feet of water behind four proposed headwater dams. ${ }^{129}$ The increased storage, in turn, promised an opportunity for all downstream American hydropower projects to increase generating capacity through the incorporation of additional (and/or more efficient) generating units at each dam.

The Columbia River Treaty called for the construction of three large storage dams in British Columbia, and it allowed for the construction of Libby Dam, with $5,000,000$ acre-feet of storage, on the Kootenai River in Montana (with a reservoir that backed up forty-two miles into Canada). ${ }^{130}$ According to Article II of the treaty, "Canada shall provide in the Columbia River basin in Canada 15,500,000 acre-feet of storage usable for improving the flow of the Columbia River." Their approximate locations were specified:

a) On the Columbia River near Mica Creek, British Columbia, with approximately 7,000,000 acre-feet of storage;

\footnotetext{
${ }^{128}$ Willingham, Army Engineers and the Development of Oregon, 158. When completed in 1968, the John Day Dam added another 500,000 acre-feet of storage to the system.

${ }^{129}$ Blumm, "The Northwest's Hydroelectric Heritage," 274 - 275; Willingham, Army Engineers and the Development of Oregon, 164.

${ }^{130}$ For the details of treaty-authorized development of the Kootenai River, including the allowance for U.S. construction of Libby Dam in Montana, see Donald Spritzer, Waters of Wealth: The Story of the Kootenai River and Libby Dam (Boulder, Colo.: Pruett Publishing Company, 1979); and Columbia River Treaty Documents (Treaty between the United States of America and Canada relating to cooperative development of the water resources of the Columbia River Basin, and the documents associated therewith) (Portland, Oreg.: U.S. Department of Interior, 1971), The Columbia Treaty, Article XII, 8.
} 
b) Near the outlet of Arrow Lakes, British Columbia, with approximately $7,100,000$ acre-feet of storage; and

c) On one or more tributaries of the Kootenay River in British Columbia downstream from the Canada-United States of American boundary with storage equivalent in effect to approximately $1,400,000$ acre-feet of storage near Duncan Lake, British Columbia. ${ }^{131}$

Each of Canada's three dams was assigned specific flood control storage plans, for which the United States agreed to pay a combined $\$ 64,400,000 .{ }^{132}$ The treaty also dictated the timetable for the completion of each dam and penalties for delay. Once the treaty was fully ratified, Canada—or, more specifically, British Columbia—was obligated to complete the Arrow Lakes Dam and Duncan Dam within five years and Mica Dam within nine years. ${ }^{133}$

As compensation and incentive for constructing the dams in Canada, the treaty stipulated the sharing of all downstream power benefits equally between the two countries. ${ }^{134}$ According to Article VII(1), "The downstream power benefits shall be the difference in the hydroelectric power capable of being generated in the United States of American with and without the use of Canadian storage, determined in advance." 135 While the treaty did allow for the possibility of the United States and Canada to formally negotiate for the disposal of "portions of the downstream power benefits" in the United States, in the absence of such agreement, the treaty clearly

${ }^{131}$ Columbia River Treaty Documents, The Columbia Treaty, Article II, 3.

${ }^{132}$ Ibid., Article VI(1), 5. Flood control compensation was to be paid by the United States to Canada "upon the commencement of operation of the storage": 1) $\$ 1,200,000$ for Mica Dam; 2) $\$ 52,100,000$ for Arrow Lakes Dam; and 3) \$11,100,000 for Duncan Dam.

${ }^{133}$ Ibid., Article IV(2), 5 - 6. Flood control storage specified for each dam: 1) Mica Dam with 80,000 acre-feet; 2) Arrow Lakes Dam with 7,100,000 acre-feet; and 3) Duncan Dam with 1,270,000 acre-feet. ${ }^{134}$ According to Article VII of the treaty, "the downstream power benefits shall be the difference in hydroelectric power capable of being generated in the United States of America with and without the use of Canadian storage."

${ }^{135}$ Columbia River Treaty Documents, The Columbia Treaty, Article VII(1), 6. 
called for the downstream power benefits to be delivered to Canada as "dependable hydroelectric capacity" and "usable hydroelectric energy.",136

In order to provide half of the downstream power benefits to Canada (also referred to as the "Canadian entitlement"), the treaty directed the United States to "deliver to Canada at a point on the Canada-United States of America boundary near Oliver, British Columbia, or at such other place as the entities may agree upon," the power owed to Canada. ${ }^{137}$ The delivery of the Canadian entitlement generated within the United States required the construction of extra-high voltage transmission lines and terminals to transmit power to Oliver and then westward to Vancouver, British Columbia. To cover the subsequent costs accrued to the United States, the treaty required Canada to pay " $\$ 1.50$ United States dollars a year for each kilowatt of dependable hydroelectric capacity included" in the Canadian entitlement. And, in order to "improve system stability of the east-west circuits in British Columbia," the treaty directed the United States to provide east-west standby transmission service adequate to safeguard the transmission" between Oliver and Vancouver. ${ }^{138}$

\footnotetext{
${ }^{136}$ Ibid., Article VII, 6.

${ }^{137} \mathrm{Ibid}$., Article $\mathrm{V}(2)$. In order to ensure maximum efficiency in the production of the downstream benefits, Article III(1) of the treaty stipulated:

The United States of American shall maintain and operate the hydro electric facilities included in the base system and any additional hydroelectric facilities constructed on the main stem of the Columbia River in the United States of America in a manner that makes the most effective use of the improvement in stream flow resulting from operation of the Canadian storage for hydroelectric power generation in the United States of America power system.

${ }^{138} \mathrm{Ibid}$., Article X. Because no viable east-west extra-high voltage transmission line existed between Oliver and Vancouver, British Columbia, the B.C. government was faced with two basic options to receive their entitlement of electrical power: 1) Negotiate a new delivery point with the United States -that more directly integrated their existing grid to the Columbia River system; or 2) Build an eastwest intertie that stretched across the western half of southern British Columbia. In the spring of 1961, the B.C. Power Commission approached the BPA to begin working out arrangements to deliver power the Canadian entitlement to Blaine, Washington (due south of Vancouver, B.C.) instead of Oliver.
} 
British Columbia's government, under the leadership of Premier William Andrew Cecil (typically referred to as W. A. C.) Bennett, ultimately refused to accede to the treaty's instruction that the Canadian entitlement be delivered by the BPA for sale in Canada. The root of Bennett's intransigence grew from his desire to industrially develop the Peace River Basin in northeastern British Columbia. The introduction of Columbia River power into the province threatened the centerpiece of Bennett's vision for the Peace River Basin, because it relied on the development of the Peace's hydropower potential. The only way Bennett was going to commit British Columbia to the ratification of the treaty, was if a solution could be found that allowed for the parallel development of both the Peace and Columbia rivers. This "two-river policy" position was made well known during the treaty negotiations, but the Canadian government mistakenly discounted Bennett's commitment to developing the Peace as mere posturing. ${ }^{139}$ During the ensuing stalemate in Canada over the ratification of the treaty, Bennett clearly stated his insistence on developing the Peace River system to Robert Jameison of Montreal's Financial Times.

The Peace is going ahead. It's a matter of high policy. We're going to develop that country, and there's nothing much to be gained in priceif anything - by building the Columbia... The country's ripe for opening up. It's got gas, oil, minerals and some of our best timberland. We've pushed roads and the railway in and I believe we'll see a new industrial empire up there, electro-chemical plants, petro-chemicals, primary reduction of ores are some possibilities. This isn't just a pipe dream. ${ }^{140}$

\footnotetext{
${ }^{139}$ Northwest Power and Conservation Council, "Columbia River Treaty: Design and Purposes," http://www.nwcouncil.org/history/ColumbiaRiverTreaty.asp, accessed on Mar.13, 2008.

${ }^{140}$ Edward Weinberg, Associate Solicitor, Division of Water and Power, Department of Interior, to Charles Luce, Oct. 31, 1962, and enclosed transcript of Robert Jameison's interview of W.A.C. Bennett, PNW-PSW Intertie (Apr. 1962 - Dec. 1962), Box 18118, RG 305, NARA Seattle.
} 
Even without the delivery of the Canadian entitlement to British Columbia, there was barely enough of an electrical market to cover the investment in the Peace River project. If Columbia River power was delivered into British Columbia as envisioned by the treaty, the Peace River project would suffer from the ensuing glut of power and become economically unfeasible for decades.

The most viable solution, as Bennett saw it, was for both rivers to be developed simultaneously. Accordingly, he believed that "if both are to go ahead at the same time, we just have to export some of the power, and obviously the first power to be sold in the United States is the power from our downstream benefits which is generated there."141 Beyond benefiting the Peace River development effort, the sale of the Canadian entitlement in the U.S. power market had the potential to provide British Columbia with the revenue needed to build its three treaty-stipulated dams as well. And, if the power remained in the United States, both countries could avoid the costly development of the transmission systems required to deliver power from the Columbia system into Canada and subsequent east-west connections to provide power and standby service between Oliver and Vancouver.

As early as the spring of 1961 , officials representing the government of British Columbia communicated their belief to the BPA that Canadian ratification of the treaty would likely rely on the sale of their share of downstream benefits in the United States. ${ }^{142}$ Of course, with the American half of the downstream benefits already needing to be absorbed in the Pacific Northwest, the likelihood of immediately

\footnotetext{
${ }^{141}$ Ibid.

${ }^{142}$ Bernard Goldhammer to Charles Kinney, Assistant Administrator to Ivan White, Dec. 12, 1962, Last Half 1962, McIntyre-Canadian Storage, Box 25597, RG 503, NARA Seattle.
} 
consuming the Canadian entitlement as well was a non-starter. If British Columbia was going to sell the Canadian entitlement in the United States, it was going to have to be purchased by utilities in the Southwest.

Luckily, by that time, Luce and the intertie task force had already begun their efforts to craft the regional preference legislation needed to clear the way for the construction of the Pacific Intertie system. The timing for the conceptual inclusion of Canadian power into intertie planning was ideal, and the BPA was well positioned to probe California's power market for potential customers at the same time that they distributed the first drafts of the regional protective legislation for comment. Beyond the practicality of beginning the process of determining the fair market value of the Canadian entitlement in the U.S. market, the introduction of the concept likely helped raise interest in the Pacific Intertie itself. Because the California market was especially hungry for firm power, the potential availability of Canadian power provided Californians much more incentive to support the passage of a regional preference bill and construction of the Northwest-Southwest intertie system than the availability of the BPA's secondary power alone.

Although British Columbia was not prepared to offer a solid price for the sale of the Canadian entitlement in the United States, they were able to provide "rough estimates" to the BPA by July so that agency could "survey potential markets" in California. Those estimates for "peaking capacity and energy on a firm basis" ranged from a low of $\$ 12$ per kw-year and 3 mills per kilowatt-hour to a high of $\$ 15$ per $\mathrm{kw}$ year and 4 mills per year, and the BPA included them in a questionnaire sent 
throughout California, which sought, in part to determine how much Canadian power utilities would buy at various prices offered. ${ }^{143}$ The interest was there, but with the exception of California's Department of Water Resources, the asking price was too high for the state's biggest customers. ${ }^{144}$ L.A.'s Department of Water and Power, for example, replied that they would only be willing to pay " $\$ 14.00$ per kilowatt per year and 2.5 mills per kilowatt-hour at Los Angeles," a price that included transmission costs and line losses. ${ }^{145}$ The California Power Pool, on the other hand, declined to answer the questionnaire with "specific numbers" and felt that any discussion over Canadian power was "distinctly speculative," but stated:

The rate reportedly asked by British Columbia for prospective Treaty power substantially exceeds the current incremental fuel cost of producing the energy from existing and proposed thermal stations in Southern California. Also there is a possibility that competition from future nuclear power may result in pricing Canada's asking price for power out of the market. ${ }^{146}$

The BPA reported the general findings to B.C. officials at an October 1961 meeting in Portland. If the Canadians were committed to selling their power in California, it was

\footnotetext{
${ }^{143}$ Statement on Analysis of Potential Markets in California, from Meeting of California Utilities, Portland, Oreg., Aug. 1, 1961, PNW-PSW Intertie (July 1961 - Aug. 1961), Box 18118, RG 305, NARA Seattle. One mill equals one-tenth of a cent (\$0.01).

${ }^{144}$ William Warne, Director of California Department of Water and Power, to Bernard Goldhammer, Aug. 7, 1961; Public Agencies in Southern California, Partial Summary of Answers to Questionnaire Regarding Interchange of Power over Proposed Pacific Northwest-California Intertie, prepared by the Power Operating and Maintenance Division, Statistical Section, BPA, on Aug.4, 1961; both in PNWPSW Intertie (July 1961 - Aug. 1961), Box 18118, RG 305, NARA Seattle.

${ }^{145}$ City of Los Angeles, Department of Water and Power, Power System, Answer to Questionnaire Regarding Interchange of Power over Proposed Pacific Northwest-California Intertie, July 31, 1961, PNW-PSW Intertie (July 1961 - Aug. 1961), Box 18118, RG 305, NARA Seattle.

${ }^{146}$ Presidents of Southern California Edison Company, San Diego Gas \& Electric Company, and California Electric Power Company, to Charles Luce, Sept. 22, 1961, PNW-PSW Intertie (Sept. 1961 Dec. 1961), Box 18118, RG 305, NARA Seattle.
} 
clear from the responses submitted to the BPA in 1961 that the B.C. government

would have to be flexible on the price. ${ }^{147}$

By the end of 1961, it had become obvious to American observers that much of

Canada's ratification fight was being waged over the fate of the Canadian entitlement.

On November 29, the U.S. State Department, Department of the Interior, and BPA

issued a joint statement to the media and all their employees:

The United States would be satisfied to see any, all, or none of the Canadian share of the power sold in the United States as Canada may freely decide. The basic decision on the issue of disposition of its power is obviously Canada's alone and has always been so regarded by the United States Government. ${ }^{148}$

With the Canadian stalemate continuing into 1962 , Luce found it necessary to remind his staff in March "to limit any comment on the Canadian Treaty to the framework" of the statement issued in November.

Treaty negotiations in Canada did not begin progressing beyond the stalemate until the late summer of 1962 , when the Canadian government finally started to formally explore British Columbia's position that the entitlement should be sold in the United States. ${ }^{149}$ By then, Bennett's plans to build a hydropower project on the Peace River had begun to solidify sufficiently that the Canadian government could see that

${ }^{147}$ Bernard Goldhammer to Charles Kinney, Assistant Administrator to Ivan White, Dec. 12, 1962, Last Half 1962, McIntyre - Canadian Storage, Box 25597, RG 503, NARA Seattle.

${ }^{148}$ Memo from Charles Luce to Division and Branch Chiefs, Area and District Managers, Mar. 12, 1962, Canadian Storage-Current Studies 1962, Box 25597, RG 503, NARA Seattle. During 1961 and 1962, the BPA and U.S. Army Corps of Engineers were engaged in consultations with B.C. Hydro and Power Authority regarding several engineering challenges related to the proposed Arrow Lakes dam, including complications stemming from the treaty-stipulated flood storage requirements (particularly damages projected in the Revelstoke area) and outflow problems. These consultations were given clearance by the Department of Interior and State Department.

${ }^{149}$ Printed Statement by United States Representatives, distributed at Oct. 2, 1962 Columbia River Meeting held in Portland, Oregon, Canadian Storage-Current Studies 1962, Box 25597, RG 503, NARA Seattle. 
his stubborn insistence on building up the Peace River system was more than a bluff designed to increase the size the of the Canadian entitlement. Evidence of Bennett's plans was writ large. At a special session of the provincial Legislature, convened in August 1961 at Bennett's request, the premier introduced the Power Development Act, which officially expropriated the privately owned B.C. Electric Company and directed it to absorb the Peace River Power Development Company. The Legislature, after heated debate, passed the act unanimously. ${ }^{150}$ By the end of the year, the province was well positioned to accelerate the development of the Peace River Basin. ${ }^{151}$

Plans for the construction of the Portage Mountain Dam (later renamed the W.A.C. Bennett Dam), one of the first two dams proposed for the Peace River, had proceeded by the summer of 1962 to the point where the B.C. Hydro and Power Authority began to coordinate their efforts with the BPA in order to move Bennett's "two-river policy" forward in the most efficient manner possible. ${ }^{152}$ While "the outputs and rates of installation" were still "flexible" and could vary "to suit the markets for the power and to take into account different rates of filling the reservoir

\footnotetext{
${ }^{150}$ Swainson, Conflict Over the Columbia, 201 - 203; Elliott, The Sociology of Natural Resources, 170. The B.C. Electric Company had made an enemy of Bennett by rejecting the idea of buying any power generated from the Peace River. The company believed cheaper power would be available through the development of the Columbia system. Elliot claims that Bennett's actions were also a preemptive response to the possibility of federal intervention, ostensibly designed to secure a supply of inexpensive power for the Vancouver/Victoria in the national interest. At the time, the Dominion government was looking to create a national electrical grid. If Peace River power was committed to southwest B.C., then the Canadian plains would have been denied access to the Peace's power supply.

${ }^{151}$ Robert Bothwell, Ian Drummond, and John English, Canada since 1945: Power, Politics, and Provincialism (Toronto: University of Toronto Press, 1981), 227-228.

${ }^{152}$ Gordon Kidd, B.C. Hydro and Power Authority, to Henderson McIntyre, Chief, BPA Branch of Power Resources, Sept. 18, 1962, Canadian Storage-Current Studies 1962, Box 25597, RG 503, NARA Seattle.
} 
during the first few years," it had become obvious to Canadian observers, at least, that British Columbia was going to develop the Peace River. ${ }^{153}$

Representatives from the U.S. and Canadian negotiating teams began sitting down together in an attempt to work out the details of how to sell the Canadian entitlement in the U.S. power market at a three-day meeting held in Washington, D.C. on September 11, 12, and 13. At that meeting, the Canadian negotiating team, led by Hugh L. Keenleyside, Chairman of B.C. Hydro and Power Authority, submitted a formal proposal for consideration by the United States. The proposal contained five basic points:

1. There should be a contract to sell to the BPA Canada's entitlement to the downstream benefits resulting from the Columbia projects envisaged in the Treaty.

2. The contract should be between the BPA and the B.C. Hydro and Power Authority, which has been designated as the Canadian entity.

3. The contract should be for the life of the Treaty provided that if Canada's requirements for power necessitate such action Canada may, after a period of 10 years and on 10 years' notice, reduce the amount of power sold under this agreement.

4. Canada will sell the Canadian entitlement of energy to the United States at 5 mills and, in accordance with the terms of the Treaty, it is understood that capacity will be exchanged for energy, this energy also to be paid for at 5 mills on the basis of an agreed formula.

5. Bonneville, or some other United States Government agency, will make money available for the construction of the Columbia projects, this money to be provided at the interest rate that is charged by the United States when supplying funds for hydro projects in the United States. ${ }^{154}$

\footnotetext{
${ }^{153}$ Ibid.

${ }^{154}$ Agreed Summary of Supplementary U.S. Comments on Certain British Columbia Proposal, Oct. 2, 1962, Canadian Storage-Current Studies 1962, Box 25597, RG 503, NARA Seattle. The Canadian government's shifting attitude toward a new national policy supporting the export of surplus power from Canada to the United States was formally announced through a throne speech of September 27, 1962.
} 
Returning to the table again on October 2 for a two-day meeting in Portland, the U.S. representatives responded to the Canadians' September proposal rather coldly. The Americans were open to the idea of having the Canadian entitlement sold in the U.S. market, but they saw the BPA as a third-party involved in the transactions rather than a viable purchaser of that power. While they were willing to speed up the payment of the flood control benefits in order to help finance the construction of Canadian storage projects, they did not foresee Congress subsidizing the public works of a wealthy industrialized nation. In regard to the contemplated price being floated by the Canadians for the sale of their entitlement in the U.S. market, American negotiators concluded:

It was not believed that the United States could pay more for the Canadian entitlement than the United States market would justify on the basis of the cost of alternate sources of power...a cost substantially less than a five mill rate for the Canadian entitlement at a $60 \%$ load factor.

Additionally, the U.S. representatives thought that the purchase of the Canadian entitlement at a price above the United States market would in effect amount to a derogation of the principle of the equal sharing of benefits upon which the Treaty was negotiated. ${ }^{155}$

Furthermore, the U.S. team believed that both parties to the treaty should be granted identical privileges to terminate the contracts stemming from the sale of the entitlement in the United States.

In addition to almost wholly rejecting the Canadians' proposal, the U.S. negotiators then suggested four alternatives of their own. First, they suggested that the Canadians simply ratify the treaty without any further delay. Specifically, this would

${ }^{155}$ Ibid. 
have meant the disposal of the Canadian entitlement directly to British Columbia in the form of electricity, with the possibility for surplus power to be marketed in the U.S. market if desired. Americans were happy with the terms of the treaty already. "If the agreed approach [of 1961] is to be discarded, it is important to understand that it is a Canadian decision based upon domestic Canadian considerations, and that it is not a decision in which the United States government participated."156

Second, if the Canadians agreed to move forward with the ratification of the treaty, the U.S. team proposed that a block of power drawn from the Canadian entitlement should be sold in the United States. In regard to the sale of the entitlement, the U.S. believed the Canadians could obtain a better price if they agreed to sell the power under long-term contracts. For example, contracts drawn up for periods of at least thirty years would raise the value of the block of power because it would match the standard lifespan of a thermal plant. The revenue generated from the sale of the block of power could then be applied to the costs of dam construction in British Columbia. ${ }^{157}$

The third and fourth alternatives both concerned the timing of British Columbia's treaty-based commitment to build Mica Dam. If the Canadians were to agree to the first two points, then the U.S. team saw an opportunity for British Columbia to pay for the construction of Mica Dam by installing generating capacity immediately on construction, marketing the subsequent power generated in the United States. Alternatively, if the Canadians deemed it to be more advantageous to delay the

\footnotetext{
${ }^{156}$ Statement by U.S. Representatives at Meeting, Oct. 2, 1962, Canadian Storage-Current Studies 1962, Box 25597, RG 503, NARA Seattle.

${ }^{157}$ Ibid.
} 
completion of Mica Dam even longer than the nine years contemplated by the treaty, the U.S. team was willing to modify the treaty to expand the allowable schedule to seventeen years. ${ }^{158}$

The international face-off over the fate of the Canadian entitlement picked up where it left off when talks resumed in Vancouver, B.C., on December 19, 1962. This time, the U.S. team delivered a formal proposal to the Canadians. As described by Ivan B. White, Chairman of the U.S. negotiating team, the proposal was "really a stool resting on six legs":

1. An Exim Bank credit for five years equivalent to the flood control benefits for the first two dams at not to exceed $4.5 \%$ interest.

2. Federal appropriations to build transmission lines to California to carry a portion of the Canadian entitlement to markets, to be constructed on a Federal interest basis.

3. The long-term purchase at 3.75 mills United States or 4 mills Canadian of the Canadian entitlement by public entities in the United States - the quantity to be maintained constant for thirty years.

4. Public entities on the main stem of the Columbia to finance the balance of the costs of the first two dams, Arrow and Duncan, through the advance purchase of $26 \%$ of the entitlement.

5. The Dominion and British Columbia governments to take the financial responsibility for that part of the cost of Mica storage and Mica generation and transmission required additional to the cash flow from balance in the United States of the remaining $74 \%$ of the entitlement.

6. The Dominion and British Columbia governments to have the responsibility for making marketing decisions regarding Mica generation power and to decide whether construction of Mica is to proceed according to the Treaty or, alternatively, whether these governments desire to discuss with the United States government rescheduling arrangements for Mica construction." 159

\footnotetext{
${ }^{158}$ Ibid.

${ }^{159}$ Statement of Ivan B. White, Dec. 19, 1962, Last Half 1962, McIntyre - Canadian Storage, Box 25597, RG 503, NARA Seattle.
} 
The Canadian team, which, according to U.S. Consul General Hayden Raynor, "regarded this meeting as one which would have a 'seriously influencing effect' upon the future course of the B.C. Government," walked away from the meeting without achieving any of their agenda. ${ }^{160}$ With Bennett standing firm in his insistence of receiving five mills per kilowatt-hour of the Canadian entitlement and the Americans unwilling to commit to a price that the domestic market would not support, negotiations were at an impasse. To spur the British Columbia government toward a reasonable compromise, the U.S. negotiating team made it clear that the Canadian delays had renewed interest in viable alternative plans to achieve flood control and storage without Canada's help. Additionally, the U.S. government was continuing to move forward with power projects, most being hydropower, already planned and authorized in the Columbia River Basin. ${ }^{161}$ According to the U.S. proposal to the Canadians, "If alternative power and storage projects should proceed prior to Canadian ratification of the Treaty, the benefits from the Canadian storage would be substantially reduced and it would be necessary to modify the Treaty accordingly."

According to White, it was entirely possible that the "apparent stalemate pointed to the inevitable conclusion that the Treaty signed...would fail." ${ }^{\prime 162}$ Still, the

\footnotetext{
${ }^{160}$ Confidential Memo from Hayden Raynor to Charles Luce, Dec. 21, 1962, Last Half 1962, McIntyre-Canadian Storage, Box 25597, RG 503, NARA Seattle.

${ }_{161}$ Other power projects mentioned by the U.S. negotiating team included: Bruces Eddy (Clearwater River in Idaho), Knowles-Paradise (near confluence of the Flathead and Clark Fork Rivers in Montana), Nez Perce or Big Mountain Sheep (on the Snake in Idaho-Oregon), Lower Monumental, Little Goose, Lower Granite, Asotin, and China Gardens dams (on the Snake River), Wells Dam (on the Columbia), Boundary Dam on the Pend Oreille, and the Hanford and Cle Elum thermal-electric plants." See Proposal of U.S. Representatives Relative to Implementation of the Columbia River Treaty, Dec. 19, 1962, Last Half 1962, McIntyre-Canadian Storage, Box 25597, RG 503, NARA Seattle.

${ }^{162}$ Statement of Ivan B. White, Dec. 19, 1962, Last Half 1962, McIntyre-Canadian Storage, Box 25597, RG 503, NARA Seattle.
} 
potential benefits to both nations arising from the successful ratification of the treaty deserved "one final try," particularly since "the collapse of this treaty would be a confession of failure by both countries" and "a defeat for the free world."163

Matters remained substantively unchanged until the summer of 1963 , when the British Columbia and Ottawa governments finally worked out their differences over the fate of the downstream benefits. The thawing of relations between the provincial and Dominion governments began with the April election of Lester B. Pearson as Prime Minister and his appointment of Paul Martin (an ex-colleague of Keenleyside) as Secretary of State for External Affairs. The Pearson administration pursued ratification through the drafting of a protocol to aid in the clarification of certain provisions of the treaty, rather than pushing for a complete renegotiation of the treaty itself. Toward that end, Martin moved to reconcile matters with British Columbia by working with them to negotiate the terms for a draft protocol to be submitted first to Parliament and then to the U.S. negotiating team. ${ }^{164}$

On May 10 and 11, Prime Minister Pearson met with President Kennedy at Hyannis Port, Massachusetts, in an effort to improve U.S.-Canadian relations. ${ }^{165}$ As part of the low-key agenda, Pearson relayed his government's chosen approach toward the ratification of the Columbia River Treaty, and he predicted that the domestic reconciliation between the B.C. and Ottawa governments and the ensuing

\footnotetext{
${ }^{163} \mathrm{Ibid}$.

164 John Hilliker and Donald Barry, Canada's Department of External Affairs: Volume 2: Coming of Age, 1946 - 1968 (Montreal: McGill-Queen's University Press, 1995), 267 - 268.

${ }^{165}$ Ibid., $262-263$.
} 
Parliamentary review might take several months to accomplish. ${ }^{166}$ As it turned out, matters proceeded fairly smoothly. The meetings with B.C. officials commenced on June 3 and 4, with an agreement finalized and signed on July 8 and sent to Parliament for review. ${ }^{167}$ A draft protocol was then produced by Parliament on July 18 and reviewed by B.C. before meetings were scheduled with the United States. ${ }^{168}$

The B.C.-Ottawa agreement settled most outstanding matters of domestic conflict over the treaty. Most importantly, British Columbia had prevailed in its struggle to sell the Canadian entitlement in the United States. It would, in turn, use the money raised from the sale of its downstream benefits, along with the flood control payments, to pay for the cost of building the treaty-stipulated dams. British Columbia Hydro and Power Authority would also become the Canadian entity responsible for carrying out the technical terms of the treaty. The Dominion government committed its resources toward the negotiation of the protocol with the United States and would proceed "with due diligence" toward the ratification of the treaty. ${ }^{169}$

International negotiations over the Columbia River Treaty resumed on August 1 and 2 in Ottawa and were followed in Washington on September 6. At the latter meeting, the Canadian team responded to the U.S. proposal submitted in December 1962 with five points:

1. It was undesirable and impractical for a Canadian entity to act as its own salesman in the United States;

\footnotetext{
${ }^{166}$ Ibid., 268.

${ }^{167}$ Columbia River Treaty Documents, Canada-B.C. Agreement, July 8, 1963, 49 - 53.

168 Hilliker and Barry, Canada's Department of External Affairs, 268 - 269.

${ }^{169}$ Columbia River Treaty Documents, Canada-B.C. Agreement, July 8, 1963, 49 - 53.
} 
2. There was no assurance there would be a market for all the Canadian entitlement or that the price was a firm one (except for a small proportion of the entitlement);

3. Canada could not afford to sell at the price offered;

4. The suggested methods of financing, while going some distance toward what Canada had in mind, did not go far enough;

5. On the other aspects of the United States proposal agreement could probably be reached. ${ }^{170}$

In response, the U.S. team, which included members of private power companies and Northwestern public utility districts for the first time, pointed out that they still didn't consider the BPA to be a feasible purchaser of the Canadian entitlement. Setting up Bonneville as the buyer would be "unprecedented and would require appropriations which we [Department of Interior] would not want to seek and probably would not get." ${ }^{\prime 71}$ The U.S. team suggested a more viable alternative might be the creation of a U.S. entity with the sole purpose of buying and selling the Canadian entitlement. ${ }^{172}$

Regarding the price of the power, the U.S. negotiators reminded the Canadians that the BPA's customers already had ready access to power at less than 3.2 mills per kilowatt hour and were subsequently "not interested in higher priced power." ${ }^{, 173}$ If customers for the Canadian entitlement were to be found, they would have to be found in the California market, where energy costs were higher than in the U.S. Northwest. They also informed the Canadians that Congress was currently working out appropriations to begin construction of the Pacific Intertie, and so a transmission

\footnotetext{
${ }^{170}$ Department of Interior record of meeting regarding Columbia River financing and sale of downstream benefits, Sept. 6, 1963, 1963 Canada, Box 25597, RG 503, NARA Seattle.

${ }^{171}$ Ibid.

${ }^{172} \mathrm{Ibid}$. According to the Department of Interior's record of the meeting, the representatives from the private companies thought the creation of a private entity was unnecessary.

${ }^{173}$ Ibid.
} 
system was soon going to be in place to deliver their power to market. And, again, they suggested to the Canadians that they consider selling their entitlement for at least a thirty-year period, breaking the power into two blocks of twenty and ten years if necessary. ${ }^{174}$

The Canadians pointed out that the fixed price offered to them by the U.S. was politically unrealistic for them to accept because of the predictable rise in its value over a thirty-year period. In response, the U.S. team noted "the United States was not asking for this power, had not contemplated its being sold in the United States and was therefore not in a position of haggling for an unfair price for something it wants." If Canada wanted to sell their power in the United States, they would have to acquiesce to the reality of the competitive market conditions. Furthermore, the Americans insisted that the price of 3.75 mills was arrived at because they found it to be the average cost of power marketable to California over the thirty-year period they were contemplating. "The power would be worth less than that in the first ten years and more than that in the third [ten years of a thirty-year period]. It was worked out on a long-term basis to allow pre-financing of the first two dams."175

At best, the U.S. team believed July 1964 was the soonest an independent entity could be created and the bonds sold to support the purchase of the Canadian entitlement. To expedite the process of working out the remaining details, it was agreed by both nations that two working groups be appointed, with four representatives from each side participating in each group. The first group was tasked

\footnotetext{
${ }^{174}$ Ibid.

${ }^{175}$ Ibid.
} 
with the problem of identifying the exact size of the Canadian entitlement; the second group was assigned to tackle the legal and financial challenges of creating the U.S. entity that would buy the Canadian entitlement. ${ }^{176}$

The full teams from both countries didn't meet again until December 30, 1963, when they reconvened in Washington, D.C. While progress was continuing to be made by both working groups through the end of 1963 , it was acknowledged that both sides had much to do in order lay the groundwork for full ratification of the treaty in 1964. Therefore, the negotiators worked up a final draft for the protocol, which established the parameters for the formal exchange of notes between the two countries to clarify the terms of the 1961 treaty. Importantly, the negotiators also drafted language for the first exchange of notes that committed each country to a "best effort" agreement to overcome the remaining obstacles standing in the way of the treaty's full ratification. Specifically, they agreed:

a) the Government of the United States will use its best efforts to arrange for disposition of the Canadian entitlement to downstream power benefits within the United States of America in accordance with the general conditions and limits set forth in the Attachment, and

b) the Government of Canada will use its best efforts to accomplish all those things which are considered necessary and preliminary to ratification of the Treaty as quickly as possible, including any arrangements for implementation and acceptance of the general conditions and limits set forth in the Attachment. ${ }^{177}$

\footnotetext{
${ }^{176}$ Ibid.

${ }^{177}$ Referral of Materials to Prime Minister by Paul Martin, Secretary of State for External Affairs, Dec. 30, 1963, Data to Kinney-Jan. 9, 1964, Box 25597, RG 503, NARA Seattle.
} 
Two weeks later, on January 13, 1964, the B.C. government finally agreed to the selling price of 3.75 mills per kilowatt-hour for the Canadian entitlement. ${ }^{178}$ Soon after, on January 22, the Protocol and exchange of notes agreeing to "best efforts" was signed by both nations. An "attachment relating to the terms of sale" accompanied the first exchange of notes and provided details related to the Canadian entitlement. The new schedule for the construction of Canadian storage projects called for the completion of Duncan Lake Dam on April 1, 1968, Arrow Lakes Dam (later renamed Keenleyside Dam) on April 1, 1969, and Mica Dam on April 1, 1973. The total price of the Canadian entitlement was set at $\$ 254,400,000$, to be paid in full by the U.S. government upon full ratification of the treaty. ${ }^{179}$

With the most difficult negotiations behind them, representatives from both nations continued their "best efforts" at bringing the treaty to fruition through the spring and summer of 1964. In Canada, the matter was introduced to the House of Commons on February 27, debated on March 3 and 9, and referred to the Standing Committee on External Affairs, where hearings were held from April 7 through May 21. After the conclusion of the hearings, the committee recommended the approval of the treaty and associated protocol. The House of Commons and Senate then approved the Columbia River Treaty and Protocol on June 5 and 9 respectively. ${ }^{180}$

\footnotetext{
${ }^{178}$ Draft of joint statement by Charles Luce and Hugh Keenleyside, Chairman of B.C. Hyrdo and Power Authority, dictated over phone by Denis Kennedy, B.C. Hydro, Data to Kinney-Jan. 9, 1964, Box 25597, RG 503, NARA Seattle. The price of 3.75 mills was based off a 60 percent load factor, delivered at the point of generation, in U.S. currency.

${ }^{179}$ Columbia River Treaty Documents, Protocol, exchange of notes, and attachment relating to terms of sale, $20-29$.

${ }^{180}$ Hilliker and Barry, Canada's Department of External Affairs, 270-271.
} 
In the United States, efforts were focused on the creation of a non-profit entity that would be able to sell bonds to cover the pre-purchase of Canada's downstream benefits. On May 19, the BPA publicly announced the creation of the Columbia Storage Power Exchange (CSPE), established in order to buy the Canadian entitlement generated at six federal and five non-federal dams on the Columbia River. ${ }^{181}$ Money was raised for the purchase of the Canadian entitlement through the sale of bonds to members of the Northwest Power Pool, which included private utilities and public utility districts, totaling $\$ 314,000,000{ }^{182}$ The bonds, in turn, were allocated equally between public and private utilities, with each utility essentially buying a percentage of Canada's downstream benefits.

In order to avoid having the CSPE considered as a utility, and regulated as such, it was necessary to dispose of the Canadian entitlement without the CSPE actually conducting the sales. ${ }^{183}$ Therefore, participants in the CSPE were allocated a percentage of the entitlement equal to their bond ownership, and then subsequently made their share of the Canadian entitlement available to the BPA in exchange for

${ }^{181}$ Charles Kinney, Acting BPA Administrator, to all BPA customers, May 19, 1964, Canadian Storage (Apr. 1964 - June 1964), Box 25597, RG 503, NARA Seattle.

The six federal dams are: Bonneville, The Dalles, John Day, McNary, Chief Joseph, and Grand Coulee. The five non-federal dams (owned by public utility districts) in Washington are: Priest Rapids and Wanapum (Grant County), Rocky Reach and Rock Island (Chelan), and Wells (Douglas County). With many of the region's utilities standing to benefit from the availability of both the American and Canadian entitlements of power stemming from the treaty, there was a strong incentive to assist the federal government in the efforts to secure the ratification of the treaty.

182 John V. Krutilla, The Columbia River Treaty: The Economics of an International River Basin Development (Washington, D.C.: Resources for the Future, 1967), 166.

${ }^{183}$ Conference and Telephone Call Report of Harold Kropitzer, Assistant to the Power Manager, BPA, regarding Mar. 18, 1964 Meeting of the Lawyers' Group of the Columbia River Treaty held in Seattle, March 23, 1964, Canadian Storage (Jan. - Mar. 1964), Box 25597, RG 503, NARA Seattle. If the CSPE was deemed a utility by either the Federal Power Commission or the Securities and Exchange Commission, it would have been regulated by the Federal Power Act and the U.S. Holding Company Act. 
"stipulated amounts of capacity and energy, less losses, at designated points of delivery on the Participant's system." "184 Because there was far more energy than what the Northwest could absorb in the early years of the entitlement, the BPA was positioned to deliver power that exceeded any participant's needs to markets within its transmission capabilities. California utilities were, of course, the natural customers for this power, having seen it on the horizon since 1961.

To no one's surprise, California's public and private utilities were eager to buy as much of the Canadian power as could be delivered. This foreknowledge, combined with the steady progress being made toward the creation of the Pacific Intertie was no doubt an incentive for British Columbia to push for the sale of its downstream benefits in the United States and for the American government to help arrange the unprecedented pre-purchase of such a large block of power. If there would not have been a ready market to absorb the Canadian entitlement, the history of the treaty negotiations would likely have been very different.

By summer, imminent ratification of the Columbia River Treaty provided a much-needed incentive to keep representatives from California's public and private utilities at the negotiating table working toward compromise in the ongoing efforts to create the Pacific Intertie. As it turned out, there was much more demand in California for Canadian power than what was reported to the BPA in response to their earlier queries. In fact, the demand far outstripped the supply, adding to conflicts already brewing over intertie planning in California.

\footnotetext{
${ }^{184}$ Kinney to all BPA customers, May 19, 1964, Canadian Storage (Apr. 1964 - June 1964,) Box
} 25597, RG 503, NARA Seattle. 


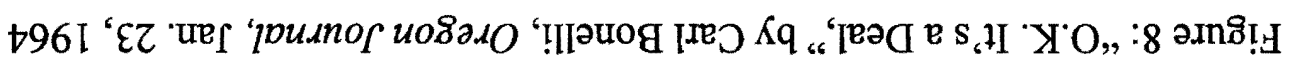
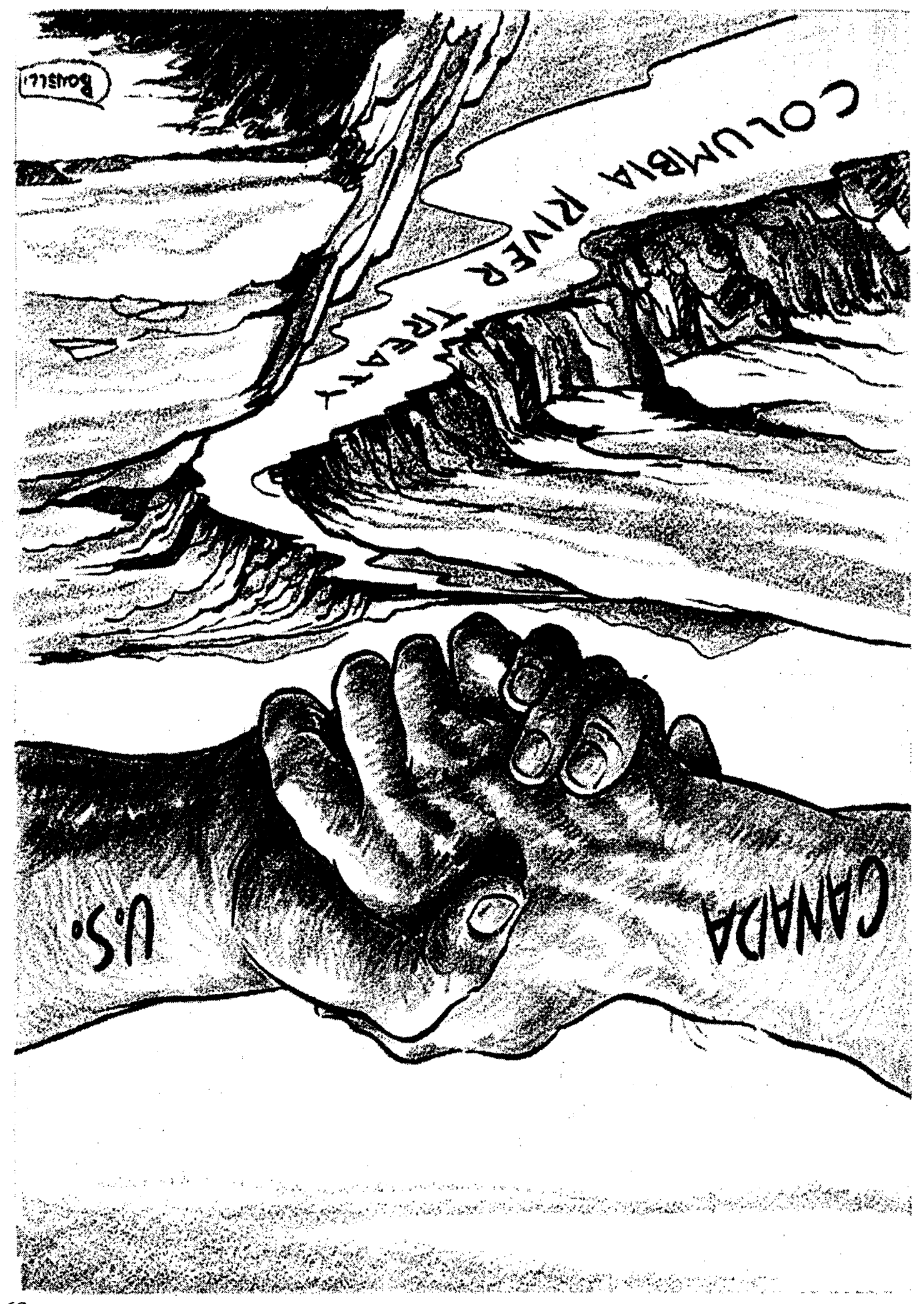
68 


\section{CHAPTER 7: The Confluence}

At the start of 1964, federal planners in the United States found themselves in an advantaged, though still tenuous, bargaining position regarding the creation of the Pacific Intertie. Congressional direction to construct at least one intertie connecting the federal hydropower systems of the Columbia River, California's Central Valley, and the Colorado River meant that even if all "good faith" negotiations failed with the California Power Pool, the BPA would likely still be able to dispose of its surplus power and meaningfully coordinate its operations with the Bureau of Reclamation as needed. The appropriation of $\$ 8.5$ million to begin the necessary tasks of acquiring land and equipment and carrying out various preliminary engineering studies demonstrated to the California Power Pool that the project had considerable Congressional support.

Progress made toward the ratification of the Columbia River Treaty only strengthened the federal planners' negotiating position. As the likelihood of the Canadian entitlement being sold in the U.S. market increased, so too did the urgency to build the Pacific Intertie system. The Canadian entitlement needed buyers, and California and Arizona utilities wanted the power to help rationalize their own operations and displace investment costs into additional power plants. As the full ratification of the Columbia River Treaty became increasingly likely through 1964, the stakes of failing to create the Pacific Intertie became high enough to keep all interested parties from walking away from the negotiating table. If a compromise could not be 
reached with California's private utilities, then the federal government would be left with little choice but to build the intertie themselves.

The year began with federal planners from the Department of Interior busy establishing a new federal yardstick for the Pacific Intertie. The revised yardstick was to be used in the evaluation of a second round of proposals, invited in response to the Congressional direction to hold "good faith negotiations with utilities and other entities interested in constructing any portion of the lines involved, that their proposals will not result in benefits to the national interest at least equal to those to be derived from Federal construction." 185 BPA invited all previously involved parties to submit "declarations of interest" to participate in the construction of an intertie system now expanded from its original Northwest-California vision to integrate Arizona's subregional grid as well. By January 14, eleven parties had declared interest in building portions of the system, including:

1. Portland General Electric

2. Pacific Power and Light

3. Pacific Gas \& Electric

4. Southern California Edison

5. San Diego Gas and Electric

6. Arizona Public Services

7. International Utilities

8. Northwest Intertie

9. Harvey Aluminum

10. Salt River Project

11. Department of Water and Power, City of Los Angeles ${ }^{186}$

The letters of interest foreshadowed another round of proposals similar to those presented to the BPA a year earlier, with two new developments. First, the inclusion

1851964 Public Works Appropriation Bill, $88^{\text {th }}$ Cong., $1^{\text {st }}$ sess., 1963, H. Rep. $902,54$.

${ }^{186}$ Kenneth Holum to Stewart Udall, Jan. 14, 1964, PNW-PSW Intertie (Jan. 1964 - Apr. 1964), 18119 , RG 305, NARA Seattle. 
of Arizona into the inter-regional transmission scheme meant that interties connecting Los Angeles, the Colorado River system (via Hoover Dam), and Phoenix would be necessary. L.A.'s Department of Water and Power, Southern California Edison, Arizona Public Services, and the Salt River Project intended to participate in the construction of any intertie facilities necessary to integrate the Southwestern systems, and they submitted letters of interest stating as much. Second, L.A. indicated that its previous support for the California Power Pool's proposal, which it declared publicly in the midst of the Department of Interior's 1963 efforts to win intertie appropriations from Congress, was not as absolute as they had previously indicated. In yet another turn around, L.A.'s Department of Water and Power stated "the City is not committed to any plan or proposal and would favor Federal construction if this would result in the most economic transmission service for the City."187 The city's waffling likely grew from the persistence of International Utilities' effort to construct a DC line stretching from the Columbia River to their doorstep. ${ }^{188}$ Competition over the transmission of Northwest power to the city's grid would certainly have been to L.A.'s advantage.

For the federal planners in charge of establishing the revised federal yardstick, the city's change in plans meant that a DC intertie passing from the Columbia River to L.A. through Nevada was viable once again. With a proposal by International Utilities already in the works, and considered by the BPA to be a "strong contender" by the end of February, Luce and his team revised their yardstick plans accordingly before

\footnotetext{
${ }^{187}$ Ibid.

${ }^{188}$ BPA Minutes of Administrator's staff meetings, Volume 4: 1963 - 1964, Feb. 26, 1964, BPA Library.
} 
announcing them to the public on March 11. The new federal yardstick for the

Pacific Intertie system called for two intertie legs to be built between the regions:

The first would be a 785-mile direct-current line from The Dalles, Oregon, to Grapevine, California, 30 miles south of Bakersfield, via Nevada. This line would be designed for 750,000 volts. The second transmission line would be a 500,000-volt alternating current line with a tap in northern California and one near San Francisco. Its first leg from John Day Dam...to Tracy...would be about 590 miles long. The second leg from Tracy to Grapevine would be about 290 miles long. Both lines would stem from the same general area of The Dalles and would terminate at Grapevine, about 50 miles north of Los Angeles. Line running from Grapevine would tie the southern terminal facility to Hoover Dam and Phoenix, Arizona, thus integrating the BPA system with the Bureau of Reclamation's Colorado River projects. ${ }^{189}$

The deadline for proposals was set for April 17, and all interested parties were asked to "demonstrate that they can build these lines and move the power better than the Federal Government and at comparable costs." 190

Upon the reception of nine formal proposals, a three-man team (consisting of Luce; Emil Lindset, Associate Chief Engineer from the Bureau of Reclamation; and Morgan Dubrow, Assistant and Chief Engineering and Technical Advisor to Assistant Secretary Kenneth Holum) was assigned the task of evaluating them in comparison to the federal yardstick established in March. ${ }^{191}$ With the exception of two proposals submitted by the Arizona Public Service Company and the Salt River Project, each wanting to build a 345-kv AC line between Hoover Dam and Phoenix, and one submitted by Los Angeles, to construct the 750-kv DC leg between the Oregon-

\footnotetext{
${ }^{189}$ Department of Interior press release: "Interior Establishes Criteria for Proposed Pacific NorthwestPacific Southwest Power Interconnection," Mar. 11, 1964, PNW-PSW Intertie (Jan. 1964 - Apr. 1964), Box 18119, RG 305, NARA Seattle. 
Nevada border to Sylmar, the proposals were already very familiar to the evaluation team. ${ }^{192}$

The proposal by Los Angeles was the most surprising. After having played the California Power Pool off against International Utilities to provide them with competing offers for Northwest energy transfers, the city had apparently decided to participate more directly in the Pacific Intertie effort. With Los Angeles proposing to build its own line, the economic feasibility of the DC leg was assured. But, there was still no guarantee that the federal planners would approve L.A.'s proposal, particularly since it appeared that L.A. was collaborating with the Power Pool, especially Southern California Edison, to a degree that made some members of Congress uncomfortable. Charles Buckley (D-NY), chair of the House Committee of Public Works, for example, was particularly incensed over the conditional language of L.A.'s proposal, which stated:

This proposal is made with the understanding that it will be considered in combination with, and is contingent upon acceptance by the United States, of the proposal to be made jointly by the Pacific Gas and Electric Company, the San Diego Gas \& Electric Company, and the Southern California Edison Company. ${ }^{193}$

The combination of even one of the two 500-kv AC lines proposed by the Power Pool and the 750-kv DC line proposed by the Los Angeles Department of Water and Power, if deemed competitive with the federal yardstick, promised to trump the federal

\footnotetext{
${ }^{192}$ Teletype from George Toman to Russ Holt, regarding Apr. 22, 1964 BPA press release, Apr. 21, 1964, PNW-PSW Intertie (Jan. 1964 - Apr. 1964), Box 18119, RG 305, NARA Seattle.

${ }^{193}$ Charles Buckley to Stewart Udall, Apr. 21, 1964, PNW-PSW Intertie (Jan. 1964 - Apr. 1964), Box 18119, RG 305, NARA Seattle.
} 
construction of any interties within California. For public power advocates like

Buckley, the deal seemed rotten. In a letter to Udall, he argued:

In my 30 years in Congress I cannot recall another instance in which the forces of monopoly have been bold enough to advance a scheme more prejudicial to the interests of power consumers in the Pacific Southwest and the American taxpayers than that which has been presented to you by the California power companies. Certainly this is the first time that a great American city has permitted itself to be used in such a strange fashion...I am indeed surprised at indications that the callous proposals of the California companies and the City of Los Angeles seemingly may have been encouraged by the Administrator for the Bonneville Power Administration, Mr. Charles F. Luce, and members of his staff. ${ }^{194}$

Buckley requested Udall to have Luce turn over any "minutes, memos, notes, schedules for meetings, correspondence, contracts, drafts, technical data or other documents" related to the aforementioned proposals. He even threatened to amend the Bonneville Power Act "to require specific authorization for all transmission lines to be built within or without the Bonneville service area" if the Department of Interior were to move forward with any plan that "would result in monopolization of surplus Bonneville Power sold in California by a combine dominated by a gigantic power company." 195

Regardless of Buckley's protest, an "interim report" on the nine proposals submitted to Udall's office from Luce's team indicated a clear preference for the L.A./Power Pool combination to complete the desired connections between the

\footnotetext{
${ }^{194}$ Ibid.

${ }^{195} \mathrm{Ibid}$. In a tactful response, dated April 24, Udall pointed out that Congress had given federal planners specific orders to carry out "good faith negotiations" with all of the utilities interested in participating in the Pacific Intertie's construction. Though he did not acknowledge Buckley's request to see all of Luce's Pacific Intertie records, he did make a commitment to include him in the same information loop as the appropriation committees. See Stewart Udall to Charles Buckley, Apr. 24, 1964, PNW-PSW Intertie (Jan. 1964 - Apr. 1964), Box 18119, RG 305, NARA Seattle.
} 
Columbia River and Los Angeles. On April 23, Luce reported his team's belief that

"the most promising combination of intertie lines appears to be the following:

\section{Columbia River to Los Angeles}

- $500 \mathrm{kv}$, ac line: Bonneville to build through Oregon connecting with PP\&L at Oregon-California line. PP\&L to build 50 miles south connecting with PG\&E at Federal cost. From there South, PG\&E and Edison to build into Los Angeles at Federal cost.

- $750 \mathrm{kv}$, de line: Bonneville to build through Oregon, connecting with City of Los Angeles at Oregon-Nevada boundary. Los Angeles to build from there into Sylmar Station at Los Angeles.

\section{Los Angeles to Hoover Dam}

- City of Los Angeles and Edison to rebuild their present 230 and $287 \mathrm{kv}$ lines, providing up to an additional $700 \mathrm{mw}$ capacity at Federal cost.

\section{Hoover Dam to Phoenix}

- Bureau of Reclamation to build first $345 \mathrm{kv}$ line. Arizona Public Service to build second $345 \mathrm{kv}$ line. ${ }^{196}$

Although the Department of Interior's final determination regarding submitted proposals would not be made official until June, negotiations among California's public and private utilities, largely regarding the terms of use of the Power Pool's intertie, commenced immediately. At the same time, federal planners resumed their attempts to: 1) win better terms from the Power Pool for the Bureau's Central Valley Project and wheeling charges for customers buying electricity over the Power Pool's lines; 2) clarify terms for the wheeling of both peak and off-peak power over L.A.'s lines (Oregon-Nevada border to L.A. and L.A. to Hoover); and 3) obtain assurances

\footnotetext{
${ }^{196}$ Interim Report on Northwest-Southwest Intertie Proposals, Apr. 23, 1964, PNW-PSW Intertie (Jan. 1964 - Apr. 1964), 18119, RG 305, NARA Seattle.
} 
regarding the purchasing of both BPA surplus power and the pending Canadian entitlement. $^{197}$

By mid-June, Canada's House of Commons and Senate had both voted for ratification of the Columbia River Treaty, and the Columbia Storage Power Exchange had already begun firming up commitments for the purchasing of bonds by members of the Northwest Power Pool in order to pre-purchase the entire Canadian entitlement. The subsequent availability (now seemingly assured) of the Canadian entitlement meant that the federal yardstick established by federal planners in March was insufficient to accommodate the expected volume of inter-regional energy transfers. Not surprisingly, federal planners expanded the size of the Pacific Intertie by accepting the Power Pool's renewed proposal to build two parallel 500-kv AC lines. ${ }^{198}$ A second DC line, built by the federal government and stretching from the Columbia River to Hoover Dam, was also added to the plans; however, the economic feasibility of this line was reliant upon electrical loads not expected to exist in Arizona until 1975. Arizona Senator Carl Hayden, chair of the Senate Appropriations Committee, was especially keen on seeing the second DC line built, so it was rolled into the appropriation request submitted to Congress in June. ${ }^{199}$

Just as it was beginning to seem that the Pacific Intertie would indeed be built, California's entire Democratic Congressional delegation balked at the plans presented

${ }^{197}$ Ibid. Also see: Kenneth Holum to Robert Gerdes, regarding clarification of the Power Pool's proposal, April 24, 1964; Conference report from Goldhammer to Luce, regarding May 5 meeting with SMUD and the latter's ongoing negotiations with the Power Pool, May 6, 1964; Supplement to Pacific Northwest-Pacific Southwest Intertie Proposal of California Utility Companies, May 9, 1964; all in PNW-PSW Intertie (Jan. 1964 - Apr. 1964), 18119, RG 305, NARA Seattle.

${ }_{198}$ The Oregon-based AC line was similarly expanded to include two parallel 500-kv lines, with the BPA building the portion of second AC line in Oregon.

${ }^{199}$ Norwood, "Administrative Challenge and Response", $80-81$. 
by the Department of the Interior. Their primary contention was that the intertie plan, as submitted to Congress by Secretary Udall, amounted to a federal subsidy supporting the growth of PG\&E's monopoly at the expense of federal, state, and municipal water projects in California. With the DC leg of the intertie passing through Nevada (without any tie-lines to Northern or Central California), advocates for the Central Valley Project and the California Water Project, in particular, felt abandoned by the plan. They were convinced that the intertie plans promised to bring undue profits to the California Power Pool, while leaving both projects' projected power needs unfulfilled. On June 23, California's Democratic delegation sent a telegram to President Johnson demanding public hearings on the plans recently submitted for appropriations by Udall. Claiming "this is a matter of deep concern to all of us in California," the congressional delegation warned Johnson that "whatever decision is made will set the pattern of power distribution from federal projects for decades, possibly forever."200

A day later, public hearings were announced by the Senate Appropriations Committee, to be held on July 1 and 2 . Before the hearings were held, Udall sent a letter to the entire California delegation in an attempt to address their concerns. In that letter he tried to frame the Pacific Intertie in its wider geographical context, explaining the federal government was still responsible for about 40 percent of the overall investment into the transmission system, with six private utilities and the City of Los Angeles responsible for 50 percent and 10 percent respectively. He recognized that

${ }^{200}$ Telegram from California Congressional Delegation to President Lyndon B. Johnson, June 23, 1964, PNW-PSW Intertie (May 1964 - June 1964), Box 18119, RG 305, NARA Seattle. 
some Congressmen felt that "because the Report did not recommend a Federal line through California, the whole Report should be shelved," only to quickly discount the idea. According to Udall, "the trouble with such a contention is that it assumes an alternative not open to us under instructions we have from Congress." To inform (or, in some cases remind) them, Udall included the relevant excerpts of the instructions given to him by the Congressional appropriations committees requiring "good faith" negotiations. He then claimed:

The City of Los Angeles and the three privately-owned electric utilities of California have offered a plan with more benefits than an all-Federal line could provide - more capacity, lower cost, and greater benefits to public agencies and other preference customers. ${ }^{201}$.

California's Democratic Congressional delegation's summary response was made through a joint statement submitted to the Senate Appropriations Committee on July 1 (and read by Congressman John E. Moss), which concluded:

We urge that the Committee direct the Secretary of the Interior that no construction of the intertie should commence, unless at least one EHV a-c line is to be built by the Federal Government from the Oregon border to the Central Valley Project, or as an alternative of desperation, unless the plan is amended to provide for increases in Federal service to Central Valley Project preference agencies to provide for their load growth. ${ }^{202}$

Under Udall's direction, the Department of Interior's negotiating team responded quickly to the crisis, and by the end of July a series of compromises were reached that allowed for intertie appropriations and the regional preference bill to begin moving forward again. Most importantly, the modified plan called for the

\footnotetext{
${ }^{201}$ Stewart Udall to John Moss and California's Democratic Delegation, June 29, 1964, PNW-PSW Intertie (May 1964 - June 1964), Box 18119, RG 305, NARA Seattle.

${ }^{202}$ Departmental Evaluation Team [Charles Luce, Emil Lindseth, and Morgan Dubrow] to Steward Udall, July 17, 1964, PNW-PSW Intertie (July 1964 - Aug. 1964), Box 18119, RG 305, NARA Seattle.
} 
Bureau of Reclamation to build and operate a portion of the intertie that allowed

the Central Valley Project to essentially circumvent PG\&E's lines in energy

exchanges with the Northwest. Specifically, the Bureau would construct:

A $500 \mathrm{kv}$ line from the California-Oregon boundary into Round Mountain station about 100 miles south of the State boundary; and from Round Mountain a $230 \mathrm{kv}$ line to Cottonwood station, where it would connect, directly and indirectly, with five existing $230 \mathrm{kv}$ lines now carrying Shasta and Trinity power southward to Tracy. Such a line would be an extension into northern California of the Bonneville $500 \mathrm{kv}$ line proposed for construction from John Day Dam to the California-Oregon boundary. The approximate cost to the Bureau of Reclamation of such lines, including substation additions, is $\$ 20,300,000$. $^{203}$

The new agreement also obtained an additional $200,000 \mathrm{kw}$ of intertie transmission capacity over the Power Pool's lines for the Central Valley Project, giving the Bureau a total capacity of $400,000 \mathrm{kw}$ through 1980 , enough to meet their customers' projected load growth until new power sources could be developed. The extra capacity for the Central Valley Project was released by the California Department of Water Resources in exchange for the BPA's and Power Pool's help in procuring what amounted to $300,000 \mathrm{kw}$ of firm power (sourced from the Canadian entitlement) to 1978 and then $150,000 \mathrm{kw}$ of firm power from 1978 to 1983 . As a result of their trade, the California Water Project gained the ability to design their water pumping system for "optimum on-peak operation." 204 As part of the deal, a related arrangement was also struck between the California Department of Water

\footnotetext{
${ }^{203}$ Stewart Udall to Carl Hayden and George Mahon (Appropriation committee chairs in the Senate and House, respectively), July 27, 1964, PNW-PSW Intertie (July 1964 - Aug. 1964), Box 18119, RG 305, NARA Seattle.

${ }^{204}$ Departmental Evaluation Team to Udall, July 17, 1964; Bernard Goldhammer to all BPA customers and Regional Advisory Council, July 23, 1964; both in PNW-PSW Intertie (July 1964 - Aug. 1964), Box 18119, RG 305, NARA Seattle.
} 
Resources and the California Power Pool to establish terms for an energy banking arrangement. The revised Power Pool intertie proposal describes this arrangement best:

At the time the State begins to purchase 300 megawatts [equivalent to $300,000 \mathrm{kw}$ ] of Canadian entitlement power...the Companies will at the State's request, on adequate notice, bank such power for the State, for subsequent use by the State during the period beginning April 1, 1978, through March 31, 1983, to enable the State to take back up to 150 megawatts during such period, thereby maintaining a rate of delivery of up to 300 megawatts...The Companies shall reimburse the State monthly for power and energy so banked and the State will repurchase such power and energy at such reimbursed price, adjusted for changes in Companies' power costs during the intervening period and service costs incurred by the Companies. ${ }^{205}$

On July 29, the Department of Interior distributed a press release announcing "all parties - private, municipal, State and Federal — have reached agreement on a plan for construction and use of the biggest single electric transmission program ever conceived in the United States." A $\$ 45.5$ million budget request was submitted to Congress to begin construction in 1964 of a transmission system capable of moving "more than four million kilowatts of power...equivalent to the output of two Grand Coulee dams or equal to the daily power needs of six San Francisco's or five Washington D.C.'s." The Pacific Intertie system was estimated to cost $\$ 700$ million, with a federal share of $\$ 300$ million. $^{206}$ With the conflicts over the Pacific Intertie

\footnotetext{
${ }^{205}$ Supplement to California Companies' Intertie Proposal, July 15, 1964, PNW-PSW Intertie (July 1964 - Aug. 1964), Box 18119, RG 305, NARA Seattle.

${ }^{206}$ Department of Interior, Office of Secretary News Release, "Pacific Northwest-Pacific Southwest Intertie Program Okayed by Federal, State, and Private Parties," July 29, 1964, PNW-PSW Intertie (July 1964 - Aug. 1964), Box 18119, RG 305, NARA Seattle. The Department of Interior's appropriation request called for $\$ 42.2$ million for the BPA and $\$ 3.3$ million for the Bureau of Reclamation.
} 
resolved, the appropriation request sailed through both houses of Congress on August 14.

A workable compromise on the regional preference bill soon followed in regards to the divisive Westland amendment. Drafted by Luce and PG\&E's Gerdes, the new language limited Congressional approval to any new federal lines not already included in the current Pacific Intertie plans. On August 18, the House passed the regional preference bill by a vote of 230 to 134 . Two days later, the Senate passed S. 1007 unanimously, and on August 31, President Johnson signed the Pacific Northwest Consumer Power Preference Act into law. ${ }^{207}$ On September 1, delayed as a result of the pre-conditional passage of S. 1007, the President signed the Public Works Appropriation Bill of 1965 , officially releasing funds to begin construction of the Pacific Intertie system.

Once the public works and regional preference bills were passed by both houses, the Columbia Storage Power Exchange was able to obtain a very favorable interest rate of 3.85 percent and subsequently sold $\$ 314$ million worth of bonds to purchase the Canadian Entitlement in one lump sum. According to Douglas Norwood's interpretation of a speech given by Bernard Goldhammer to the Western Political Science Association in March 1965:

Had the interest rate been higher than about 4.26 percent, the treaty arrangements would have had to be called off, and the intertie, presumably, would have also have fallen through. Congressional approval of the intertie was a key factor in securing the low rate of interest for the Canadian treaty bonds. ${ }^{208}$

\footnotetext{
${ }^{207}$ Norwood, "Administrative Challenge and Response," 85 - 86.

${ }^{208}$ Ibid., 86.
} 
Amid much fanfare, Prime Minister Lester Pearson and President Lyndon Johnson met in Blaine, Washington, on September 16 (at the Peace Arch International Park on the Washington-British Columbia border) to complete the ratification of the Columbia River Treaty in front of a crowd of 10,000 people. A day later, the President attended an "intertie victory breakfast" in Portland, Oregon, attended by representatives of all the major public and private utilities of the Pacific West states. ${ }^{209}$ In his short speech to the group, Johnson noted the remarkable accomplishment that had been made possible through the collaboration of public and private interests, stating: "This system is also the proof of the power of cooperation and unity. You have proved that if we turn away from division, if we just ignore dissention and distrust, there is no limit to our achievements. ${ }^{210}$ Indeed, after a half-century of divisive quarreling between advocates of public and private power groups and their advocates, history would finally show that successful collaborations were possible, even on a grand scale such as the creation of the Pacific Intertie.

${ }^{209}$ Tollefson, BPA and the Struggle for Power at Cost, 336.

${ }^{210}$ Transcript of Secretary Udall's Introductory remarks and President Johnson's speech at the Intertie Victory Breakfast at the Sheraton Hotel, Portland, Ore., Thursday, Sept. 17, 1964, BPA Library. 


\section{Conclusion}

The creation of the Pacific Intertie resulted from the culmination of years of planning, negotiation, and compromise. While some of the efforts, like those related to the Columbia River Treaty, had been going on since the mid-1940s and were carried out on an international level, the active pursuit of the intertie's creation by the BPA, following their budget crisis of 1958 , proved to be the catalyst that set the stage for the Pacific Intertie's official birth in 1964. Through the measured planning, articulated vision, and shrewd but conciliatory negotiating approach of the Department of Interior's staff, particularly at the BPA, the opportunity for success was made possible when all of the disparate forces came to rely on each others' parallel successes during the summer of 1964.

In order for the Columbia River Treaty to be fully ratified, the Canadians had to dispose of their downstream benefits in the United States. For the United States to buy those downstream benefits, an inter-regional intertie would have to be constructed to transmit the Canadian energy to market in California. The transmission of electricity from the Pacific Northwest to California, would, in turn, require legislative safeguards that limited the export of power from the region to sales of energy surplus to the region's needs. And, those needs would become a precondition for the funding of the Pacific Intertie, which was, in turn, a precondition for the success of the Canadian Treaty. That all of the forces came together in a way that produced positive results in all regards is largely a testament to the steadfast leadership of BPA 
Administrator Charles Luce and Secretary of the Interior Stewart Udall. But, it is also an indication of the potential benefits that were possible at local, state, regional, national, and even international levels.

By 1970, with construction complete on all legs, the Pacific Intertie allowed for the movement of more than 4,000,000 kilowatts of power among the electrical systems of British Columbia and eleven Western states, including 243 rural electrical cooperatives, municipal systems, and other public agencies. ${ }^{211}$ It had essentially become the backbone of the largest electrical grid in the Western world. In addition to widening the marketing area available to power producers throughout the grid, the Pacific Intertie also integrated the operations of the nation's largest hydropower system (BPA), the largest privately owned electrical system (PG\&E), and the largest municipal power system (L.A. Department of Water and Power) in the country.

As it turned out, the second DC line, stretching from the Columbia River to Hoover Dam, was never built. At first its construction was delayed until contracts could be obtained in the Southwest to make it economically feasible. ${ }^{212}$ But, once the Pacific Intertie was in place, and its capacity steadily expanded, the feasibility of a second DC leg remained tenuous. Furthermore, the development of Southern California Edison's Four Corners thermal-power project created a sizable influx of firm power into the Southwest, inevitably making the feasibility of the second dc leg impossible to obtain. The Pacific Intertie was still expanded, but its growth came in

\footnotetext{
${ }^{211}$ Department of Interior, Office of Secretary News Release, "Pacific Northwest-Pacific Southwest Intertie Program Okayed by Federal, State, and Private Parties," July 29, 1964, PNW-PSW Intertie (July 1964 - Aug. 1964), Box 18119, RG 305, NARA Seattle.

${ }^{212}$ Minutes of Administrator's staff meetings, Volume 4: 1963 - 1964, July 31, 1964, BPA Library.
} 
the form of a third 500-kv line, added to the system in 1993, which extended from The Dalles Dam to the Tesla Substation, near San Francisco. ${ }^{213}$

Since the creation of the Pacific Intertie, the lives of Westerners have become integrated through an electrical geography most often taken for granted, itself a reflection of the system's reliability. While power lines stretch overhead along our roads, across our mountains, between our homes, and even underground, the connections they make between our lives and the power systems and environments where the energy is produced go largely unnoticed. Regardless of the attention they draw, the connections are real nonetheless.

As we face the environmental challenges of the twenty-first century, our attention to these electrical connections will no doubt become ever more important. On one hand, with the grid already in place, power planners in the American West have significant flexibility in developing strategies to reduce environmental pressures currently pushing many species to the brink of extinction, particularly in our rivers. Theoretically, for example, the implementation of meaningful energy conservation strategies anywhere in the grid could create new opportunities to aid salmon by modifying the way we have managed the river system during the past half century. Advances in "green" energy technology could similarly benefit countless species and natural environments across the American West through strategies focused on conserving energy and replacing destructive production practices with more environmentally benign energy sources. Conversely, the grid's existence could just as

\footnotetext{
${ }^{213}$ Northwest Power Planning Council, "Pacific Intertie: The California Connection on the Electron Superhighway," Council Document 2001-11, May 2001. Last viewed March 24, 2008, http://www.nwcouncil.org/LIBRARY/2001/2001-11.pdf.
} 
well provide opportunities to increase the environmental problems stemming from our industrialized, energy-intensive lifestyles. If current trends persist, our per capita energy use will continue to increase, and whatever green energy technologies are integrated into the grid will necessarily become supplemental power sources.

Regardless of what the future holds, it is clear that there is much that we still need to learn about how our nation's electrical grids came to be and how they function. As equipment ages and power systems become outdated in their production strategies (fossil fuel burning and the extensive damming of our river systems, for example), there is much to be gained by understanding the history of previous generations' challenges, successes, and failures. This knowledge will no doubt help us retool what works, abandon what doesn't, and imagine new frontiers in energy production and transmission as we strive to meet the needs of our own time. 


\section{References}

Primary Sources:

Record Group 305, Bonneville Power Administration, National Archives and Records Administration, Pacific Alaska Region, Seattle, Wash.

Carl Bonelli Collection, MSS 5537, Oregon Historical Society, Portland, Oregon.

Bonneville Power Administration. Planning Considerations of a High Voltage Direct Current Interregional Transmission Line. Portland, Oreg.: Bonneville Power Administration, 1963 (hereafter BPA Library).

-----. Minutes of Administrator's Staff Meetings, Volume 4: 1963 - 1964. BPA Library.

-.-.. Report of a Missouri River Basin-Pacific Northwest EHV Interconnection. Portland, Oreg.: Bonneville Power Administration, 1965. BPA Library.

-.-.. Pacific Intertie: Large-Scale Sharing of Electrical Resources. Portland, Oreg.: Bonneville Power Administration, 1975. BPA Library.

--ar. Pacific Intertie. Portland, Oreg.: Bonneville Power Administration, ca. 1984. BPA Library.

-----.. The Columbia River Treaty Revisited. Portland, Oreg.: Bonneville Power Administration, 1989. BPA Library.

U.S. Department of Interior. Columbia River Treaty Documents (Treaty between the United States of America and Canada relating to cooperative development of the water resources of the Columbia River Basin, and the documents associated therewith). Portland, Oreg.: U.S. Department of Interior, 1971.

Secondary Sources:

Allen, Cain. "'They Called It Progress': Indians, Salmon, and the Industrialization of the Columbia River." Master's thesis, Portland State University, 2000.

Arrilaga, Jos. High Voltage Direct Current Transmission, Second Edition. London, U.K.: Institution of Electrical Engineers, 1998.

Blumm, Michael C. "The Northwest's Hydroelectric Heritage." In Northwest Lands, 
Northwest Peoples: Readings in Environmental History. Edited by Dale D. Goble and Paul W. Hirt, 264 - 294. Seattle: University of Washington Press, 1999.

Bothwell, Robert, Ian Drummond, and John English, Canada since 1945: Power, Politics, and Provincialism. Toronto: University of Toronto Press, 1981.

Bringham, Jay L. Empowering the West: Electrical Politics Before FDR. Lawrence: University Press of Kansas, 1998.

Brooks, Karl Boyd. Public Power, Private Dams: The Hells Canyon High Dam Controversy. Seattle: University of Washington Press, 2006.

Curtis, Ruth. "The Intertie Issue." Northwest Energy News 7 (March/April 1988), 12 14.

Deener, David R. Canada-United States Treaty Relations. Durham, N.C.: Duke University Press, 1963.

De Luna, Phyllis Komarek. Public Versus Private Power During the Truman Administration: A Study of Fair Deal Liberalism. New York: Peter Lang Publishing, 1977.

Dietrich, William. Northwest Passage: The Great Columbia River. Seattle: University of Washington Press, 1995.

Dominy, Floyd E. "A New Power Giant Materializes on the West Coast." Reclamation ERA 51:3 (August 1965): 66-68.

Donaghy, Greg. Tolerant Allies: Canada and the United States, $1963-1968$. Montreal: McGill-Queen's University Press, 2002.

Elliot, John. The Sociology of Natural Resources. Toronto: Butterworth \& Co., 1981.

Funigiello, Philip J. "The Bonneville Power Administration and the New Deal." Prologue 5:2 (1973): 89-97.

Hammarlund, Jeff. "Oregon's Role as an Energy Innovator: A Historical Perspective." Oregon's Future 3:1 (2002), 10 - 16.

Hanks, James F. "The Columbia River Treaty: A Case Study of International River Basin Development with Emphasis on Power Production." Master's thesis, University of Oregon, 1970.

Harrison, John and Northwest Power and Conservation Council. "Columbia River 
History Project." www.nwcouncil.org/history, last viewed on May 5, 2008.

Hays, Samuel P. Conservation and the Gospel of Efficiency: The Progressive Conservation Movement, $1880-1920$. Pittsburgh, Penn.: University of Pittsburgh Press, 1999.

Hilliker, John and Donald Barry, Canada's Department of External Affairs: Volume 2: Coming of Age, 1946 - 1968. Montreal: McGill-Queen's University Press, 1995.

Hirsh, Richard F. Technology and Transformation in the American Electric Utility Industry. New York: Cambridge University Press, 1989.

Hundley, Norris, Jr. The Great Thirst: Californians and Water: A History. Berkeley: University of California Press, 2001.

Hughes, Thomas P. Networks of Power: Electrification in Western Society, $1880-$ 1930. Baltimore, Md.: Johns Hopkins University Press, 1983.

Josephson, Paul R. Industrialized Nature: Brute Force Technology and the Transformation of the Natural World. Washington, D.C.: Island Press, 2002.

Krutilla, John V. The Columbia River Treaty: The Economics of an International River Basin Development. Washington, D.C.: Resources for the Future, 1967.

Lang, William L. and Robert C. Carriker, Eds. Great River of the West: Essays on the Columbia River. Seattle: University of Washington Press, 1999.

Lee, Kai N. and Donna Lee Klemka. Electric Power and the Future of the Pacific Northwest. Seattle, University of Washington Press, 1980.

Lowitt, Richard. The New Deal and the West. Norman: University of Oklahoma Press, 1984.

Mahar, Franklyn D. "The Politics of Power: The Oregon Test for Partnership." Pacific Northwest Quarterly 65:1 (1974), 29 - 37.

McKinley, Charles. Uncle Sam in the Pacific Northwest: Federal Management of Natural Resources in the Columbia River Valley. Berkeley: University of California Press, 1952.

McKinley, Charles. The Management of Land and Related Water Resources in Oregon: A Case Study in Administrative Federalism. Washington, D.C.: Resources for the Future, 1965. 
McMenemy, John Murray. "The Columbia River Treaty, 1961 - 1964: A Study of Opposition and Representation in the Canadian Political System." Master's thesis, University of Toronto, 1969.

Nash, Gerald. The Federal Landscape: An Economic History of the Twentieth Century West. Tucson: University of Arizona Press, 1999.

National Research Council. Managing the Columbia River: Instream Flows, Water Withdrawals, and Salmon Survival. Washington, D.C.: National Academies Press, 2004.

Northwest Power Planning Council. "Shipping Power South." Northwest Energy News $2: 3$ (1983), 1, 9- 16 .

--.-. Review of the Columbia River Treaty and the Columbia Storage Power Exchange. Portland, Oreg.: Northwest Power Planning Council, 1989.

-.-.-. "Pacific Intertie: The California Connection on the Electron Superhighway." http://www.nwcouncil.org/LIBRARY/2001/2001-11.pdf, last viewed April 17, 2008.

Norwood, Douglas. "Administrative Challenge and Response: The Role of the Bonneville Power Administration in the West Coast Intertie Decision." Bachelor of Arts Thesis, Reed College, 1966.

Norwood, Gus. Columbia River Power for the People: A History of Policies of the Bonneville Power Administration. Washington, D.C.: U.S. Government Printing Office, 1981.

Nye, David E. Electrifying America: Social Meanings of a New Technology, 1880 - 1940. Cambridge, Mass.: MIT Press, 1990.

Nye, David E. Consuming Power: A Social History of American Energies. Cambridge, Mass.: MIT Press, 1998.

Ogden, Daniel. "The Development of Federal Power Policy in the Pacific Northwest." Ph.D. Dissertation, University of Chicago, 1949.

Padiyar, K.R. HVDC Power Transmission Systems: Technology and System Interactions. New York: Wiley Press, 1990.

Petersen, Keith C. and Mary E. Reed. Controversy, Conflict and Compromise: $A$ History of the Lower Snake Development. Washington, D.C.: Government Printing Office, 1994. 
Pisani, Donald. Water and American Government: The Reclamation Bureau, National Water Policy, and the West, 1902-1935. Berkeley: University of California Press, 2002.

Reisner, Marc. Cadillac Desert: The American West and Its Disappearing Water. New York: Penguin Books, 1986.

Schenker, Alan Evan. The West Coast Intertie. Davis: Institute of Governmental Affairs, University of California, 1964.

Springer, Vera. Power and the Pacific Northwest: A History of the Bonneville Power Administration. Portland, Ore.: Bonneville Power Administration, 1976.

Spritzer, Donald. Waters of Wealth: The Story of the Kootenai River and Libby Dam. Boulder, Colo.: Pruett Publishing Company, 1979.

Swainson, Neil A. Conflict over the Columbia: The Canadian Background to an Historic Treaty. Montreal: McGill-Queen's University Press, 1979.

Tansey, Ben. Public Power Chronicle: A Guide to Public Power in the Pacific Northwest for the $21^{\text {st }}$ Century. Portland, Oreg.: Public Power Council, 2002.

Tollefson, Gene. BPA and the Struggle for Power at Cost. Portland, Ore.: Bonneville Power Administration, 1987.

Vietor, Richard H. K. Energy Policy in America since 1945: A Study of BusinessGovernment Relations. New York: Cambridge University Press, 1984.

Williams, James C. Energy and the Making of Modern California. Akron, Oh.: University of Akron Press, 1997.

Willingham, William F. Army Engineers and the Development of Oregon: A History of the Portland District U.S. Army Corps of Engineers. Washington, D.C.: Government Printing Office, 1983.

White, Richard. The Organic Machine: The Remaking of the Columbia River. New York: Hill and Wang, 1995.

Worster, Donald. Rivers of Empire: Water, Aridity, and the Growth of the American West. New York: Oxford University Press, 1985. 